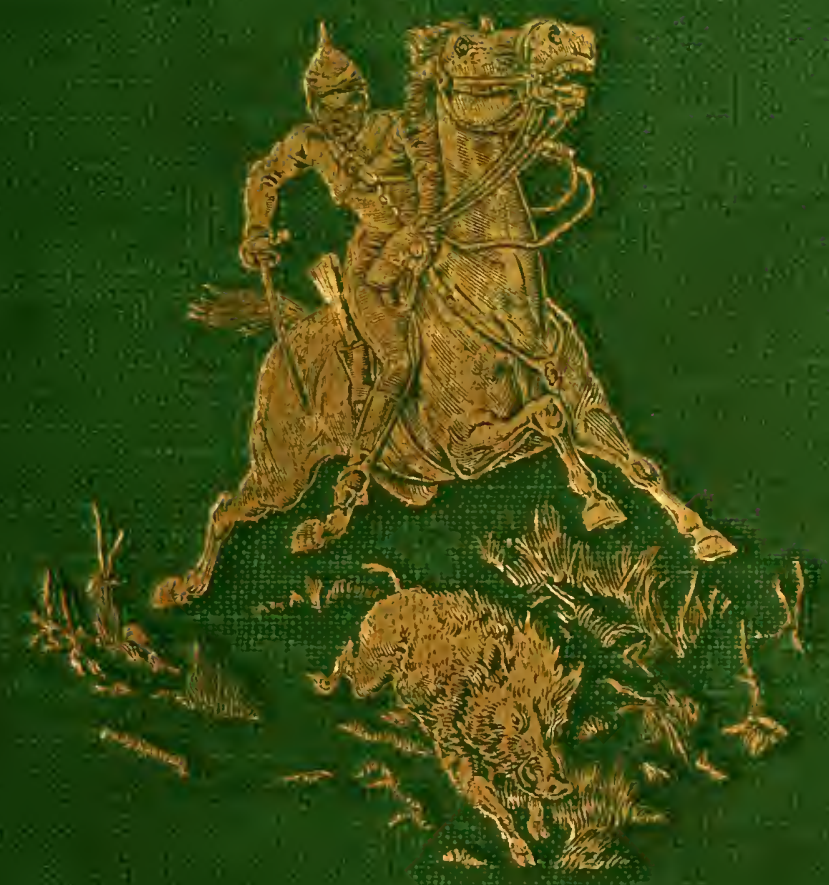




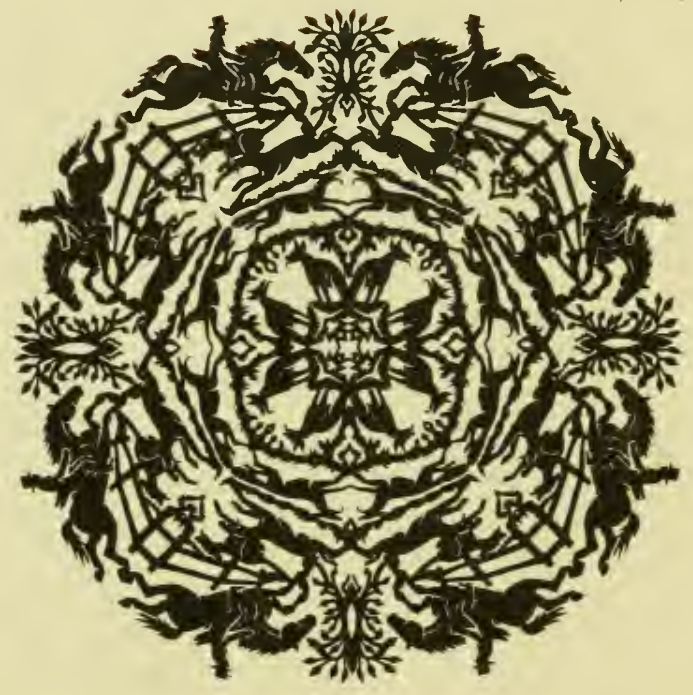

JOHN A.SEAVERNS 
Webster Family Library of Veterinary Med Cummings School of Veterinary Medicine Tufts University 200 Westboro Road North Grafton, MA 01536 



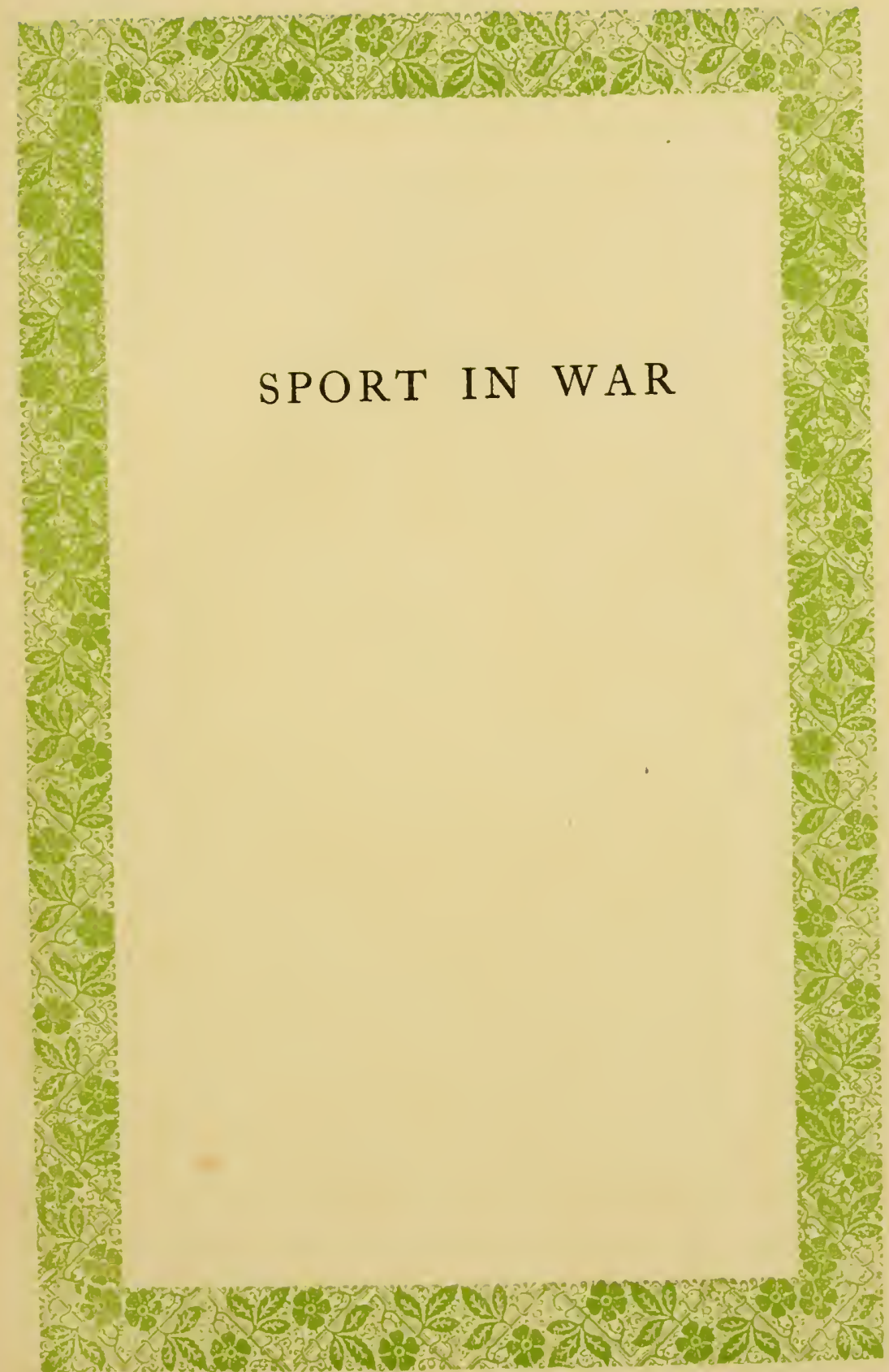




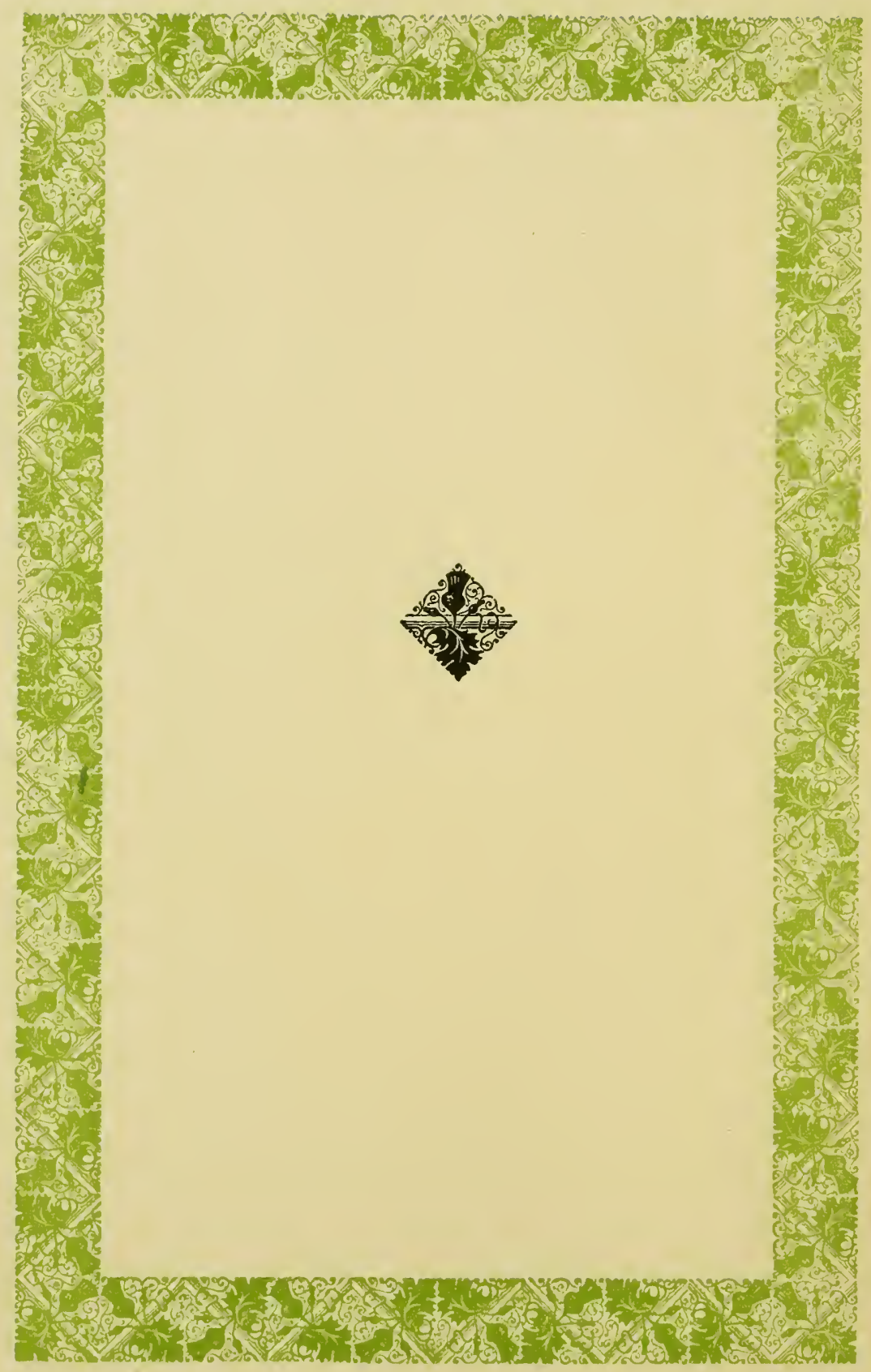





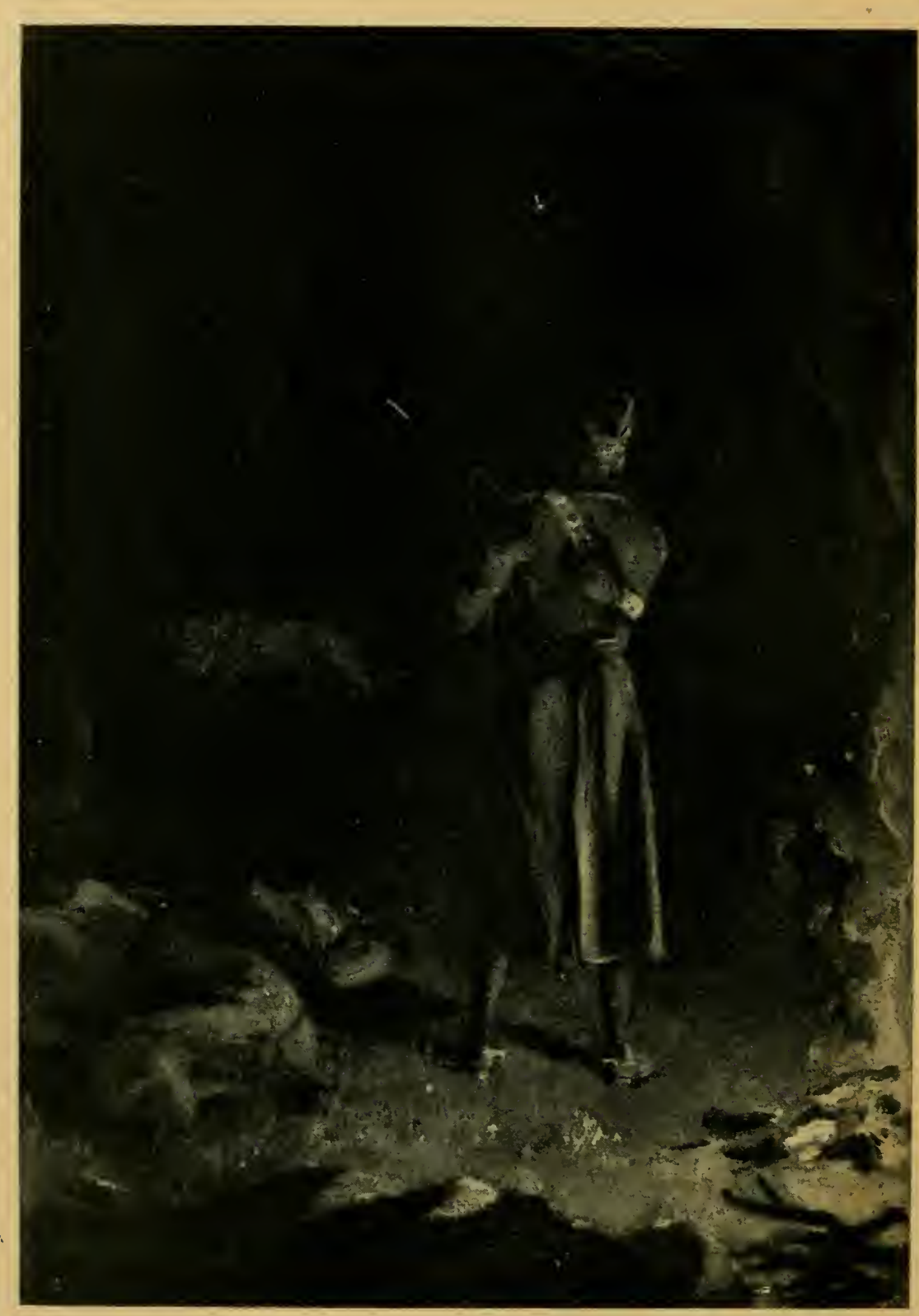

WITHIN THE HALO OF OUR WATCHFIRES 


\section{SPORT IN WAR}

BY MAJOR-GENERAL

R. S. S. BADEN-POWELL,

F.R.G.S.

With Nineteen Illustrations by the Author

Ionoon

WILLIAM HEINEMANN I 900 


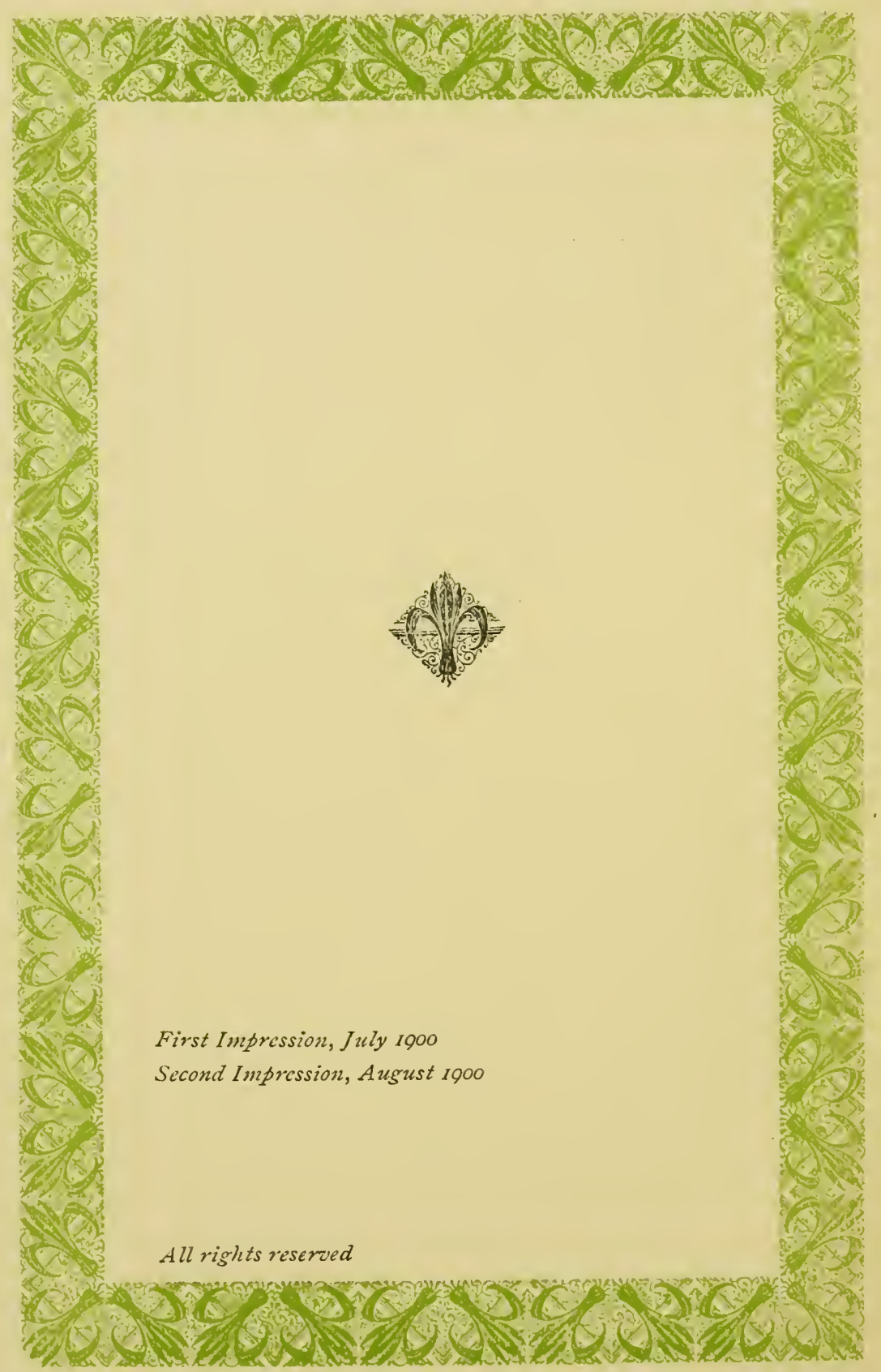




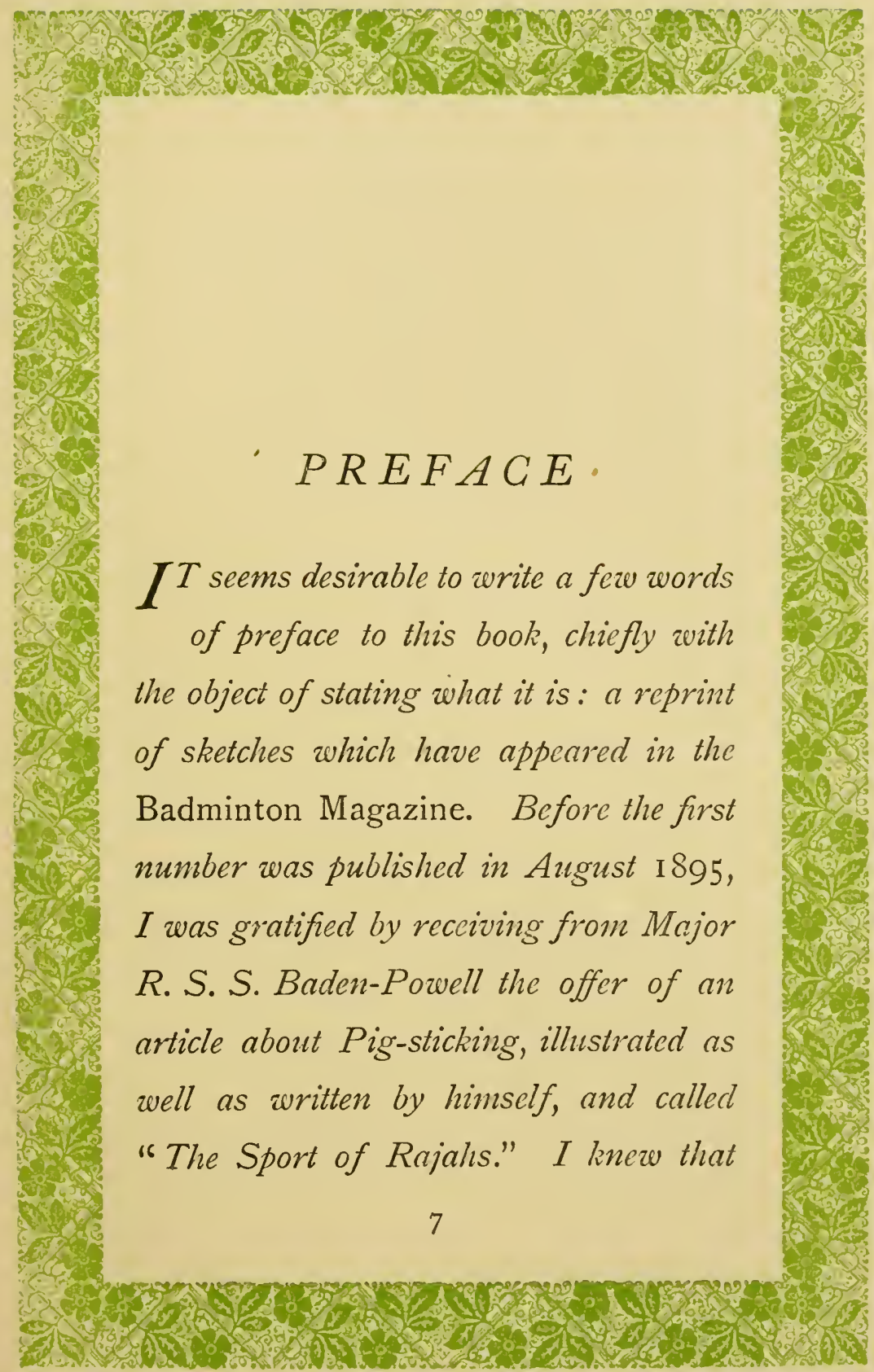




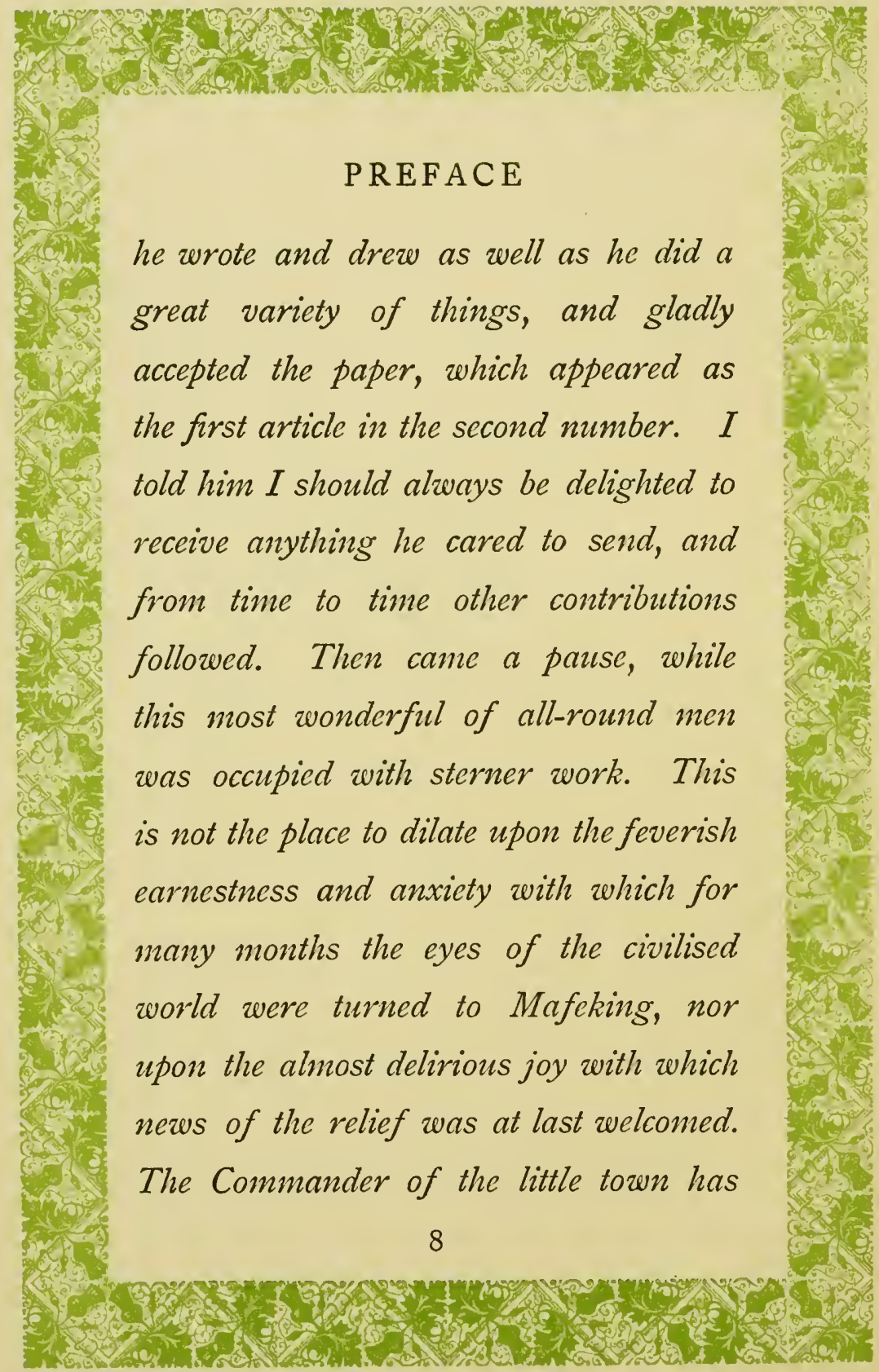




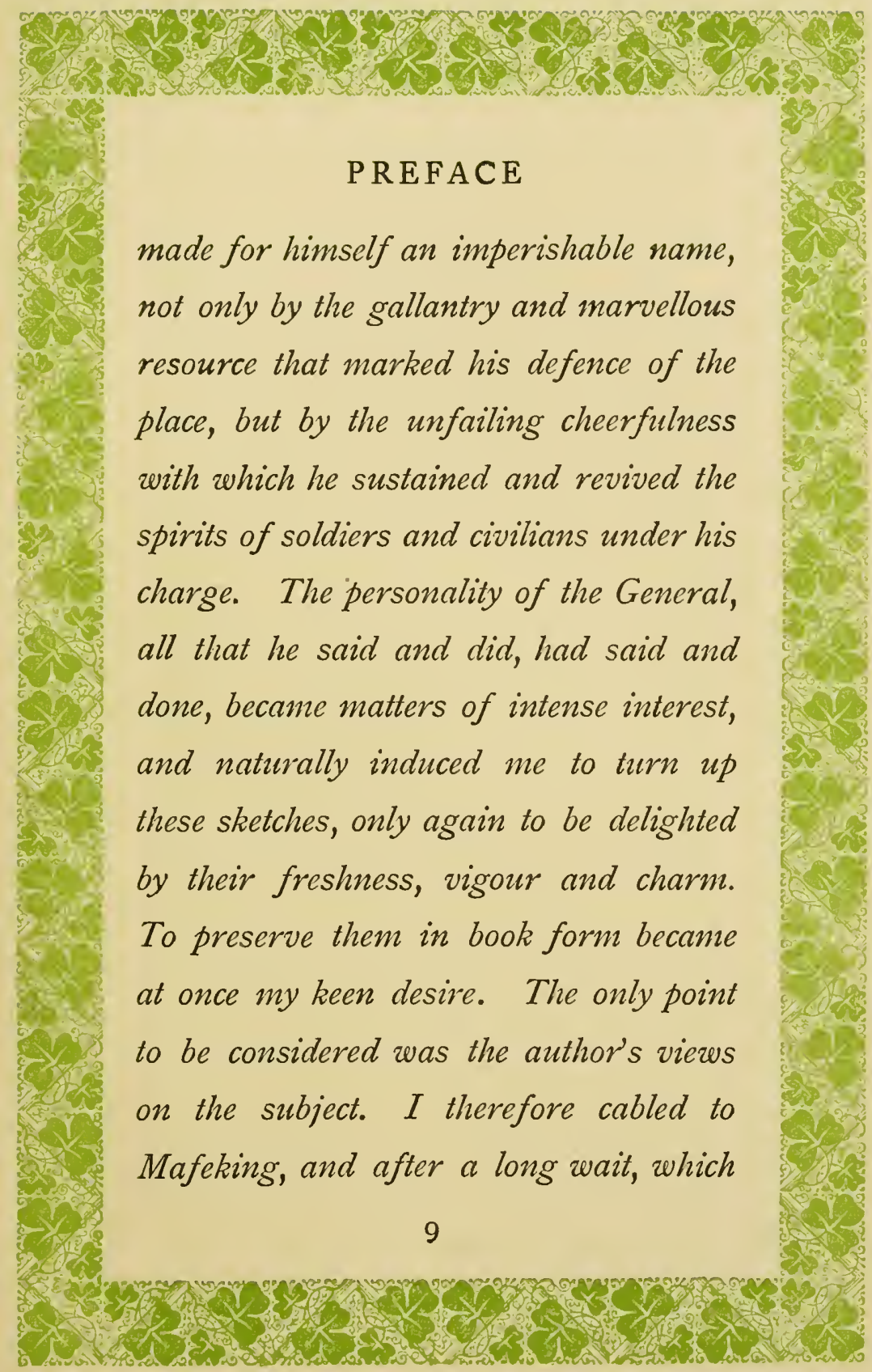




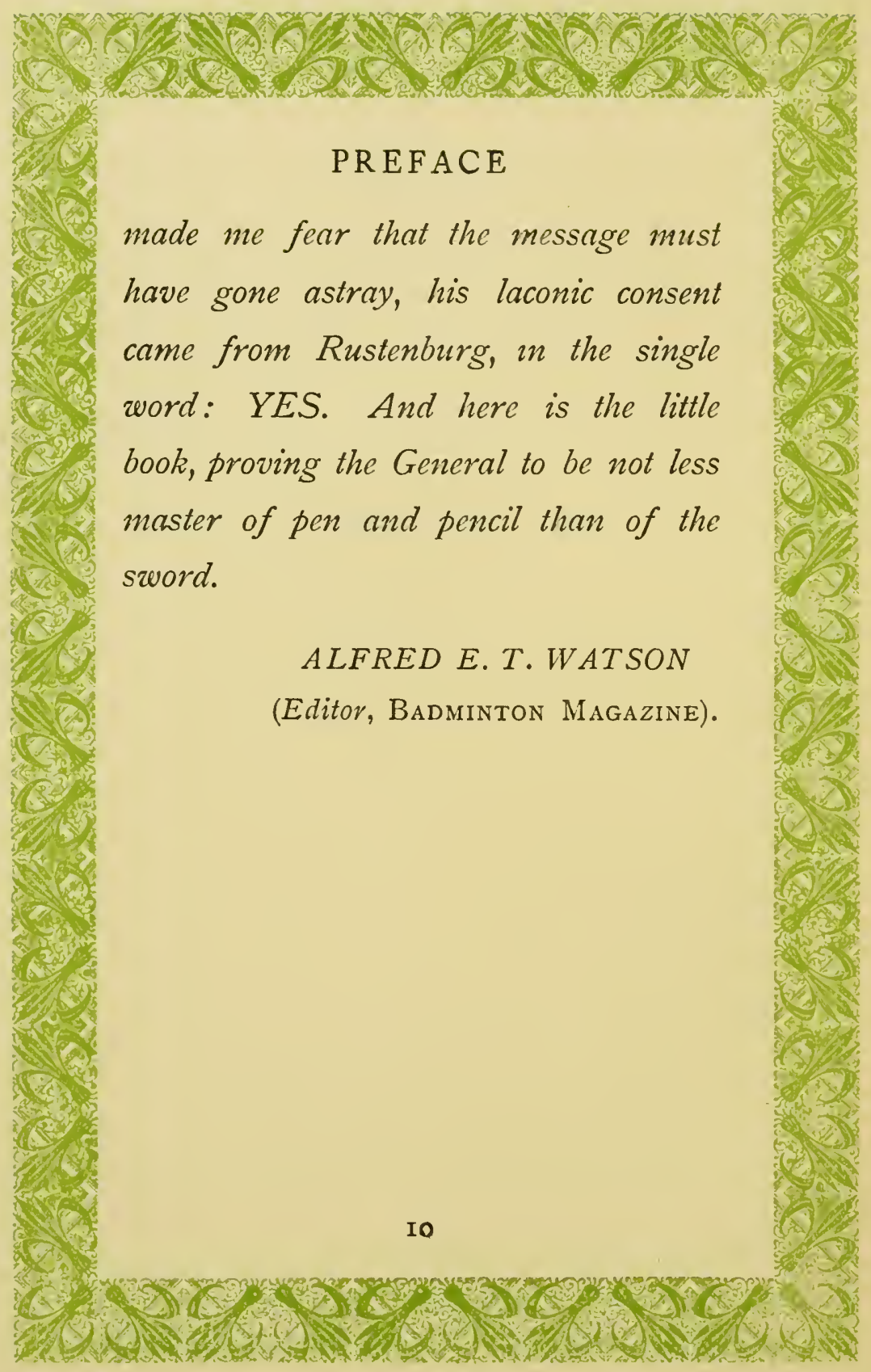




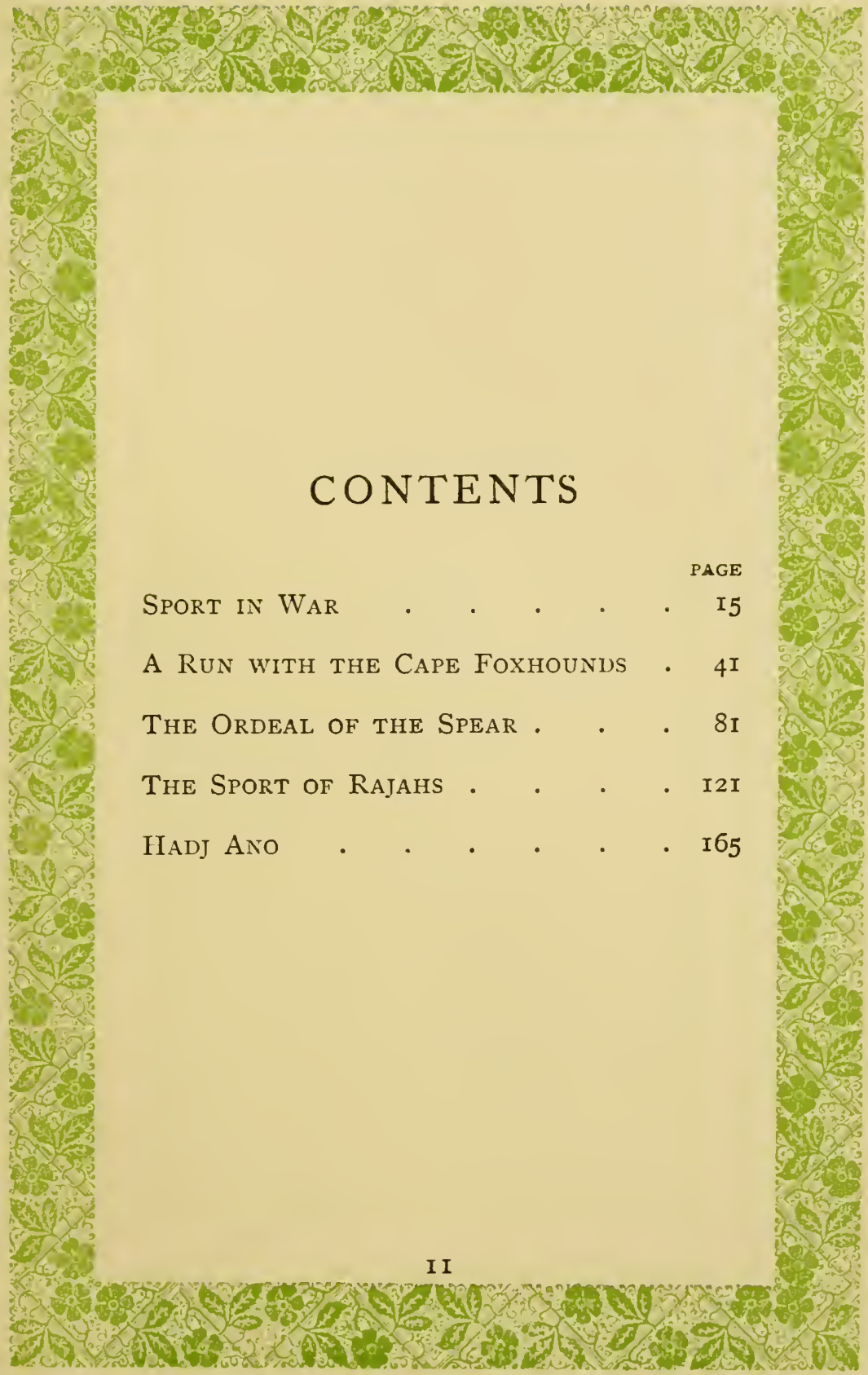




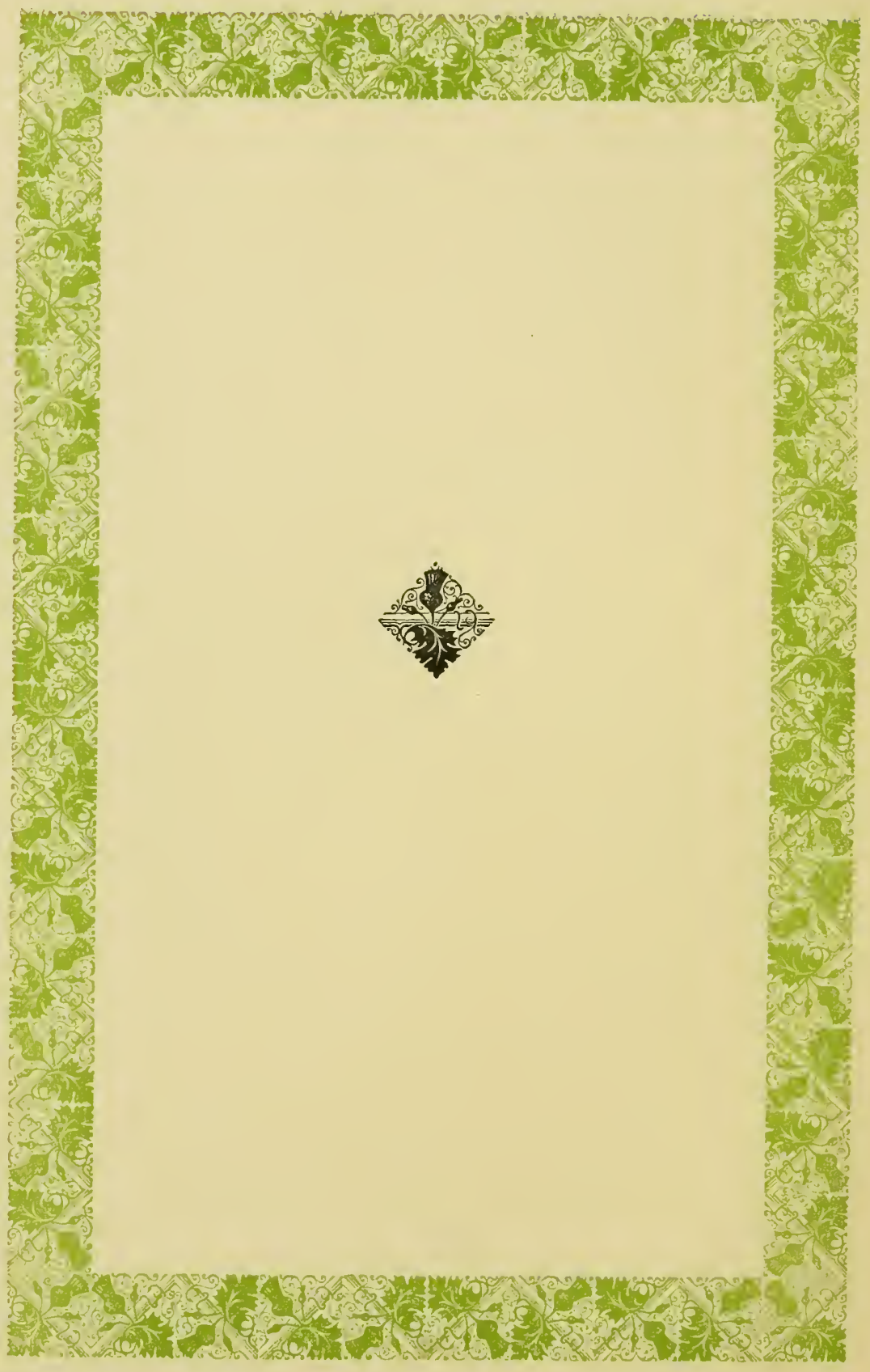




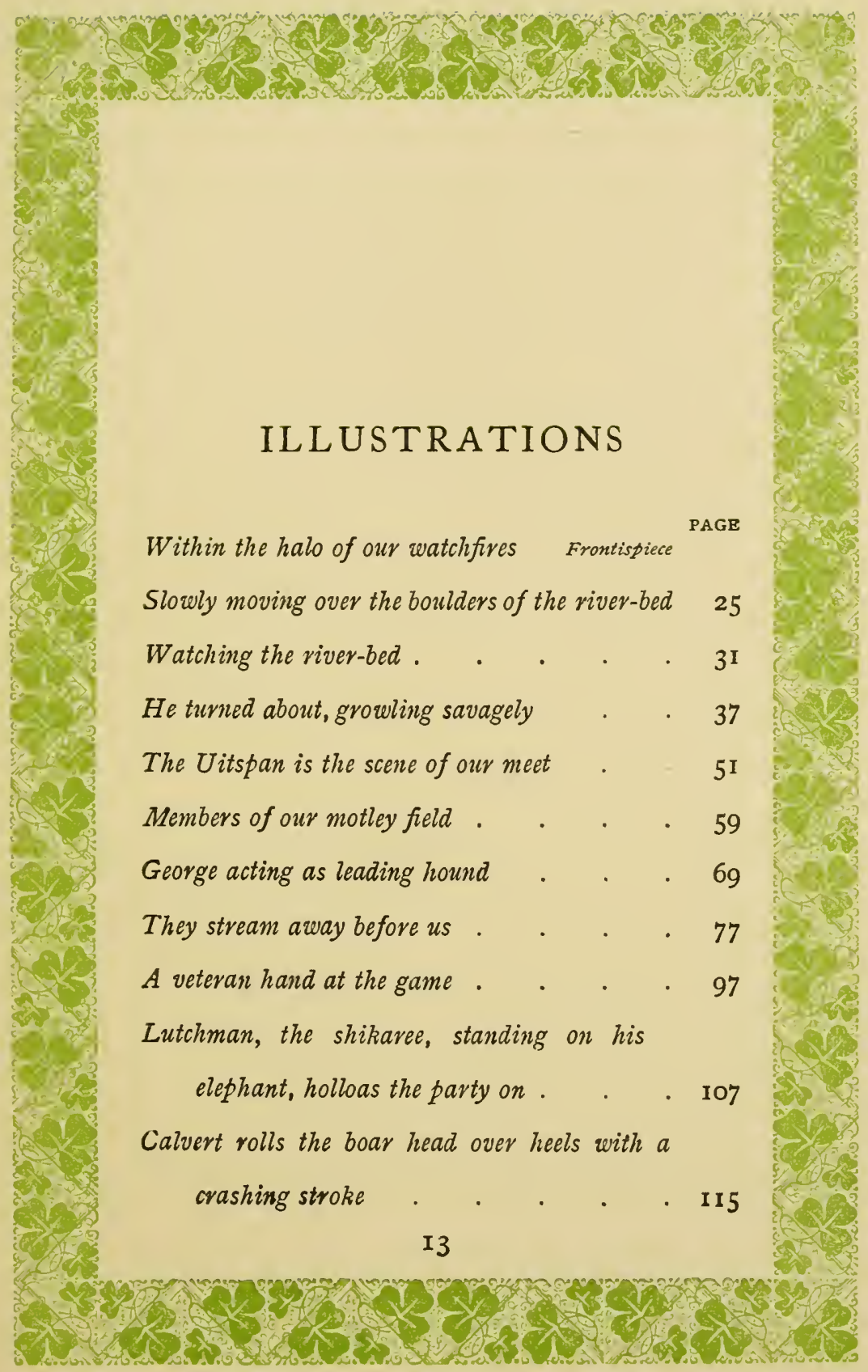




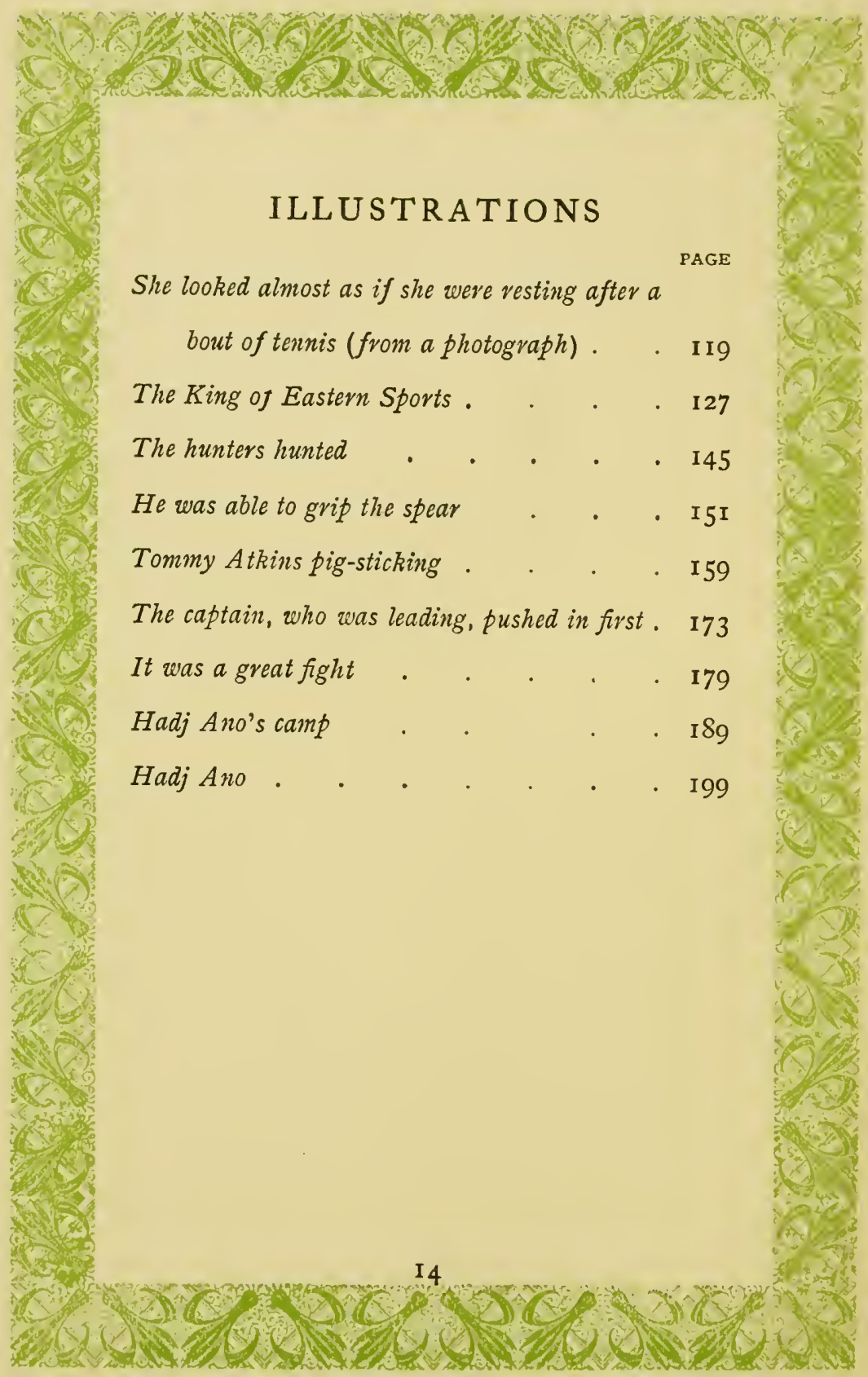




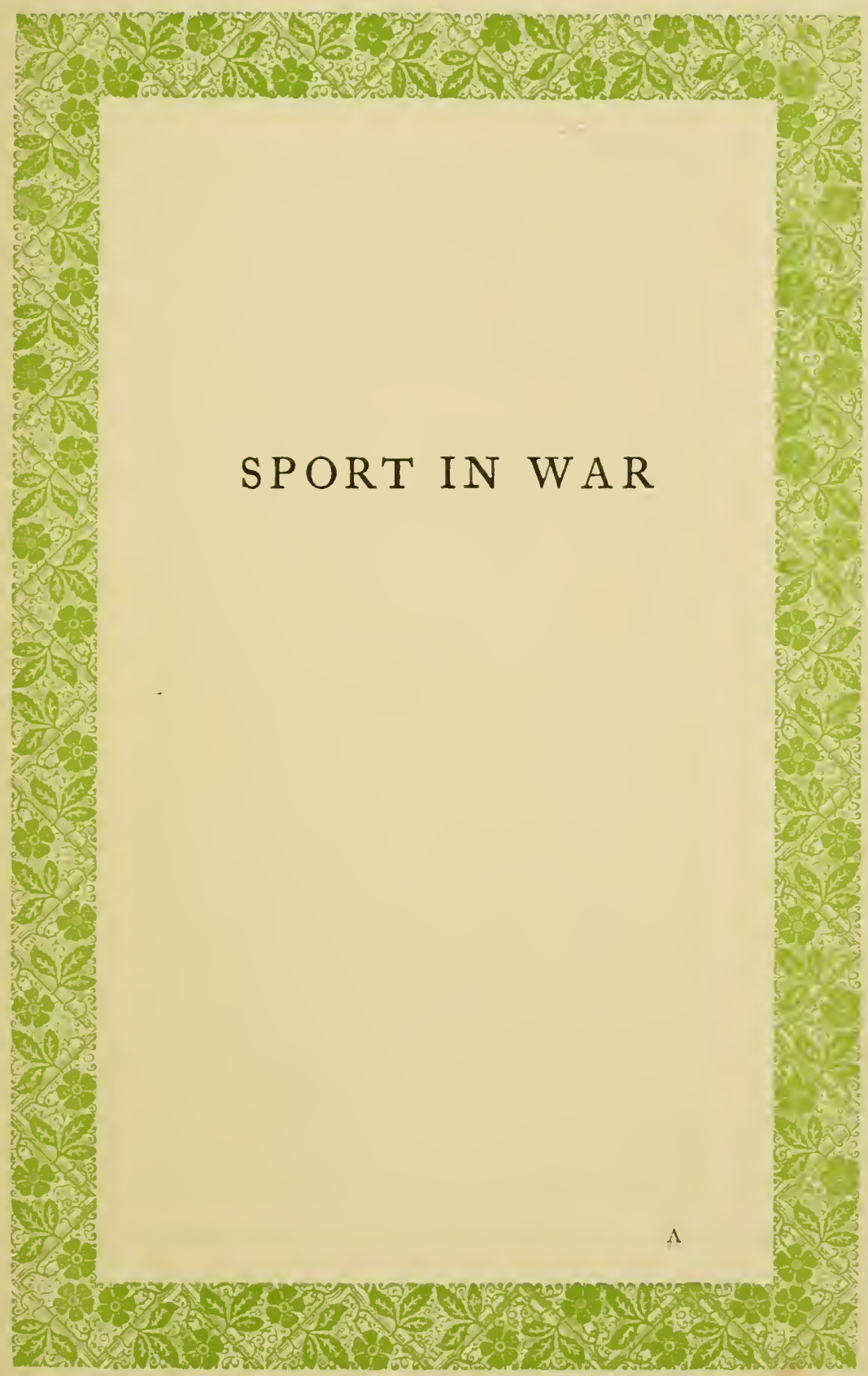




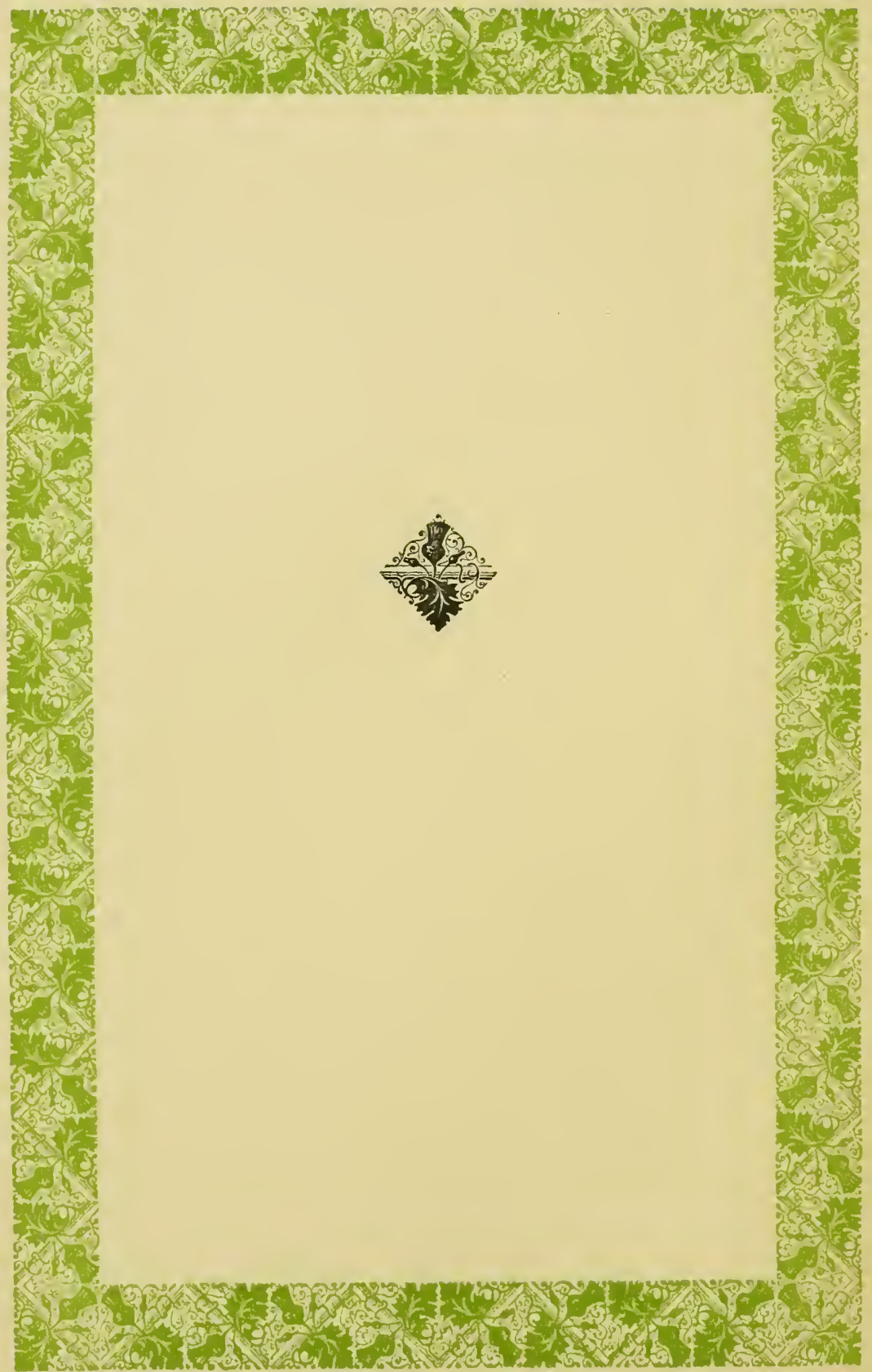




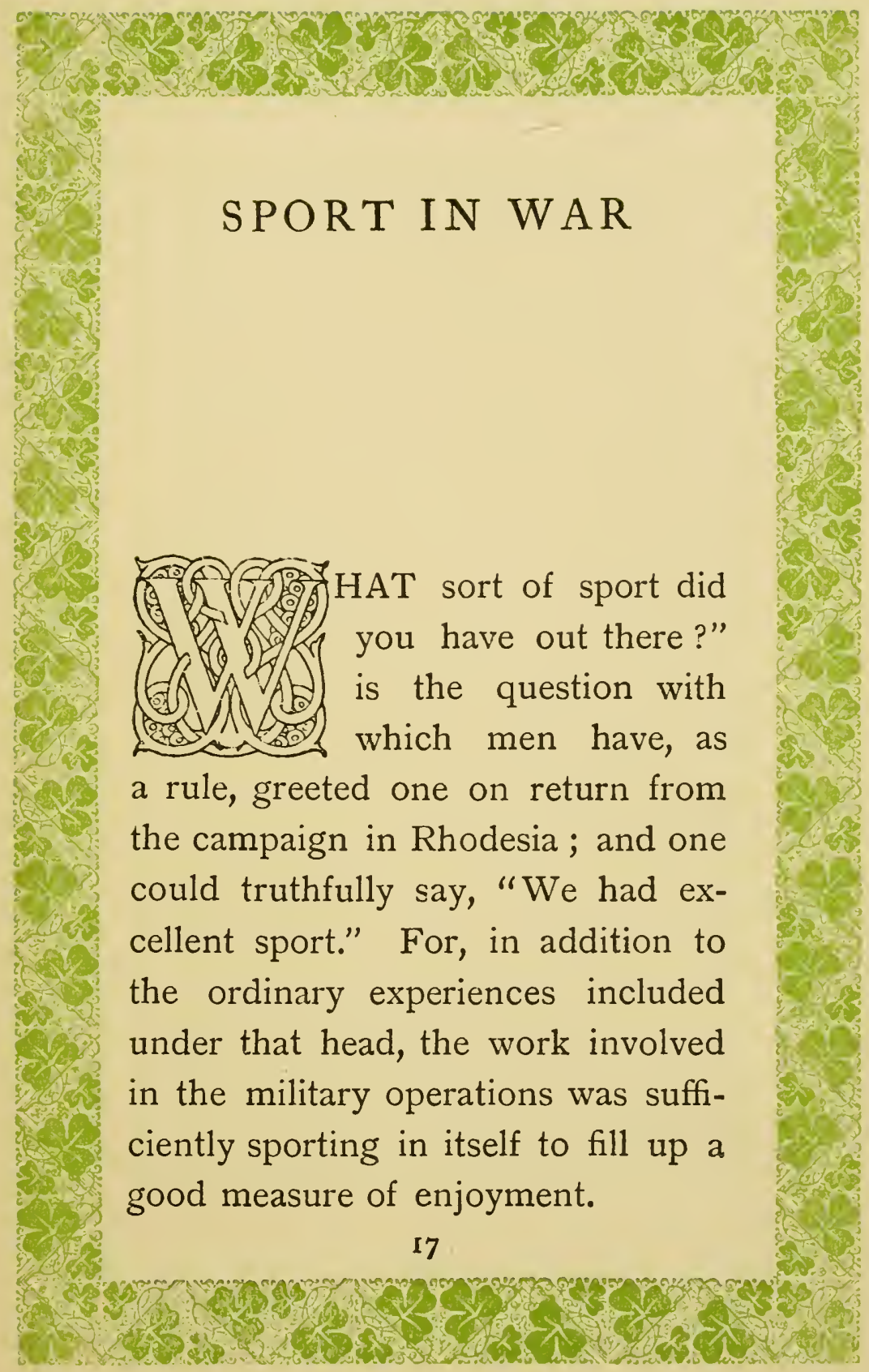




\section{SPORT IN WAR}

In the first place, scouting played a very prominent part in the preliminaries to major operations, and gave opportunities for the exercise of all the arts and resources of woodcraft, coupled with the excitement incidental to contending against wild beasts of the human kind-men of special cunning, pluck, and cruelty.

This scouting, to be successful, necessitated one's going with the very slenderest escort-frequently with one man only, to look after the horses-and for long distances away from our main body, into the districts occupied by the enemy. Thus, one was thrown entirely on one's own resources, with the stimulating knowledge that if you did not maintain a sufficient alertness of observa- 


\section{SPORT IN WAR}

tion and action, you stood a very good chance indeed, not only of failing to gain information which you were desired to seek, but also of getting yourself wiped out, as many a better man had been before, by the ruthless, bloodthirsty foe.

"Spooring," or tracking, was our main source of guidance and information, and night the cover under which we were able to make our way about the enemy's country with impunity. For a pastime involving all the points that go to make up "sport" in the eyes of the Britonviz., hard work, adventure, general discomfort, and genuine fun-commend me to scouting.

Then the actual tackling the enemy was not, especially during the latter 


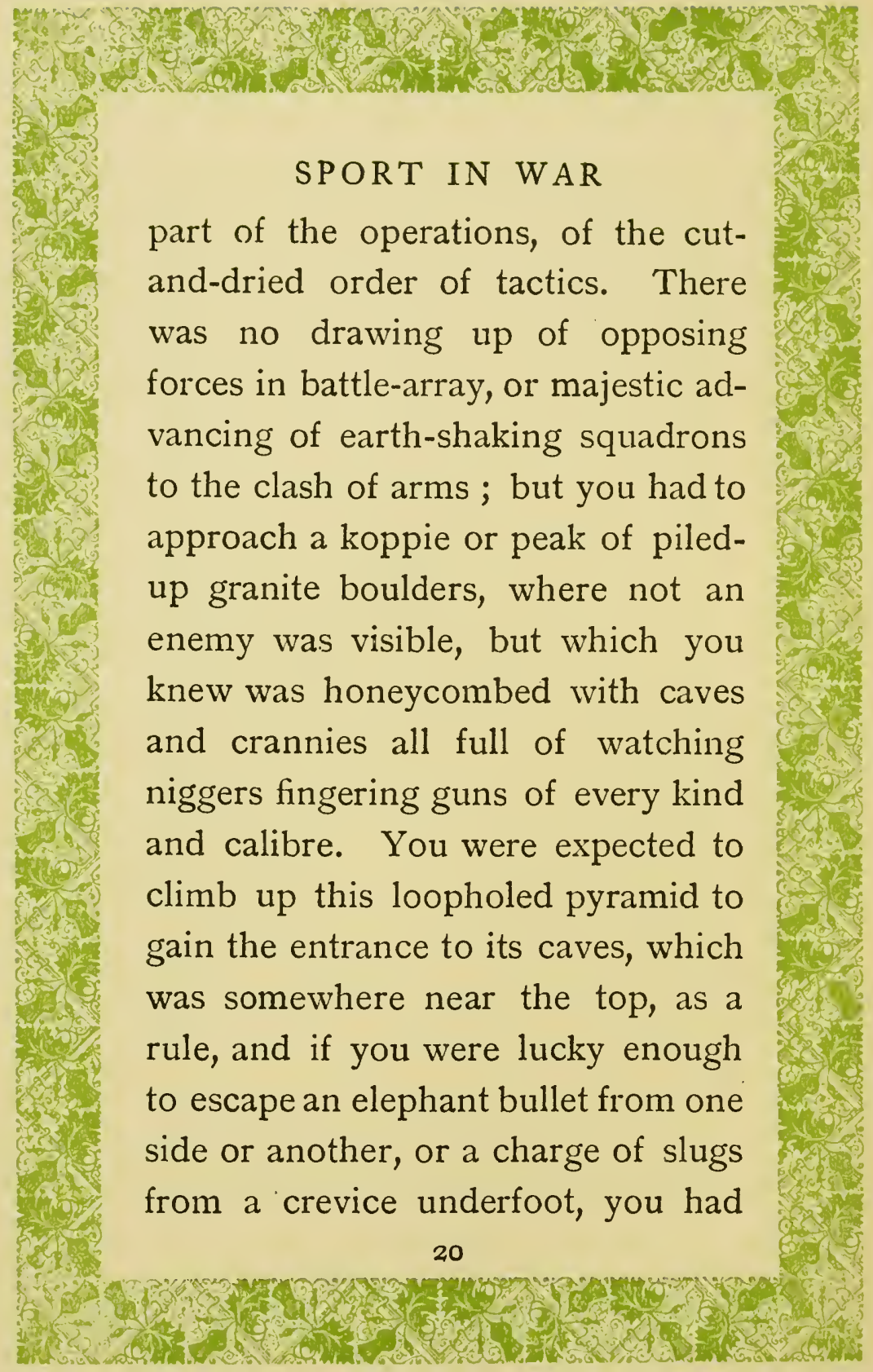




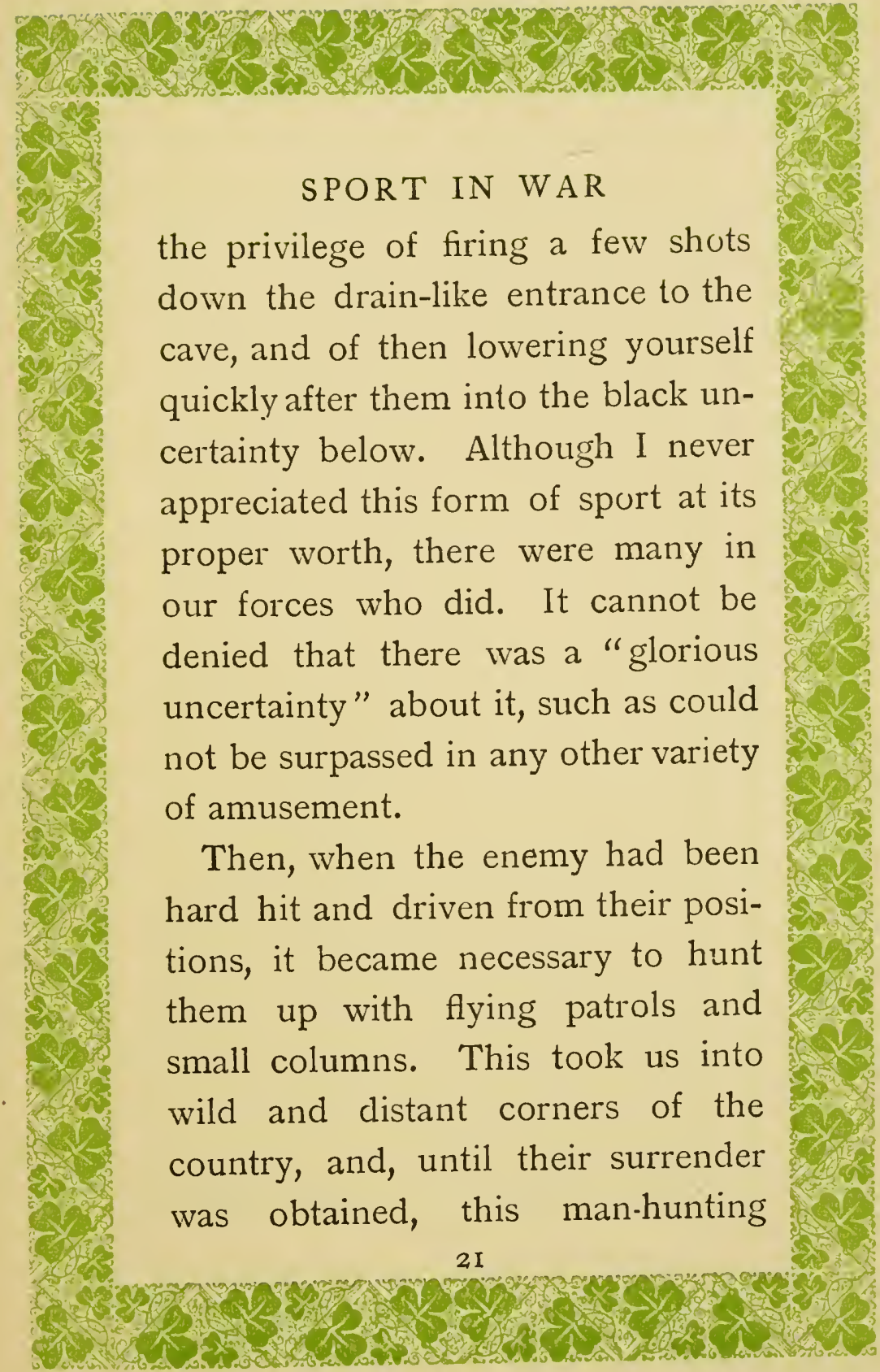




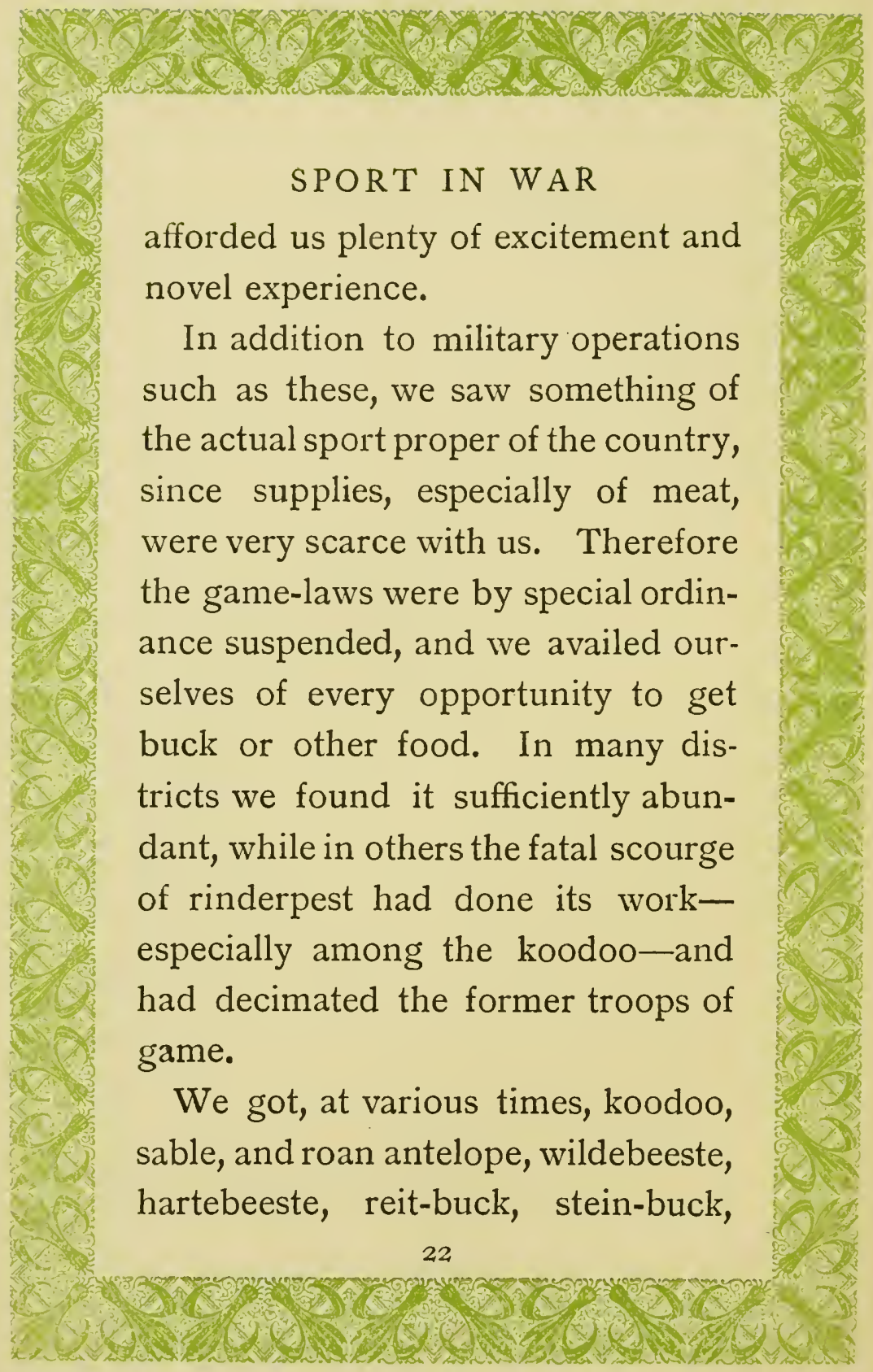




\section{SPORT IN WAR}

duyker, hares, wild-pig, quagga, and twice our patrols saw giraffe. Then of birds we saw ostriches and shot paauw, korhan, so-called pheasants, partridges, guinea-fowl, duck, and plover. And in many of the streams the men caught fish, which, though in London they might be considered somewhat overcharged with bones and mud, yet served as a pleasing variation to our daily fare of tinned ration beef.

The pleasures of the pursuit of game were all the more enhanced by the knowledge that the meat was really necessary to us, and especially by the fact that we often carried out our sport at the risk of being ourselves the quarry of some sneaking band of rebel warriors. 


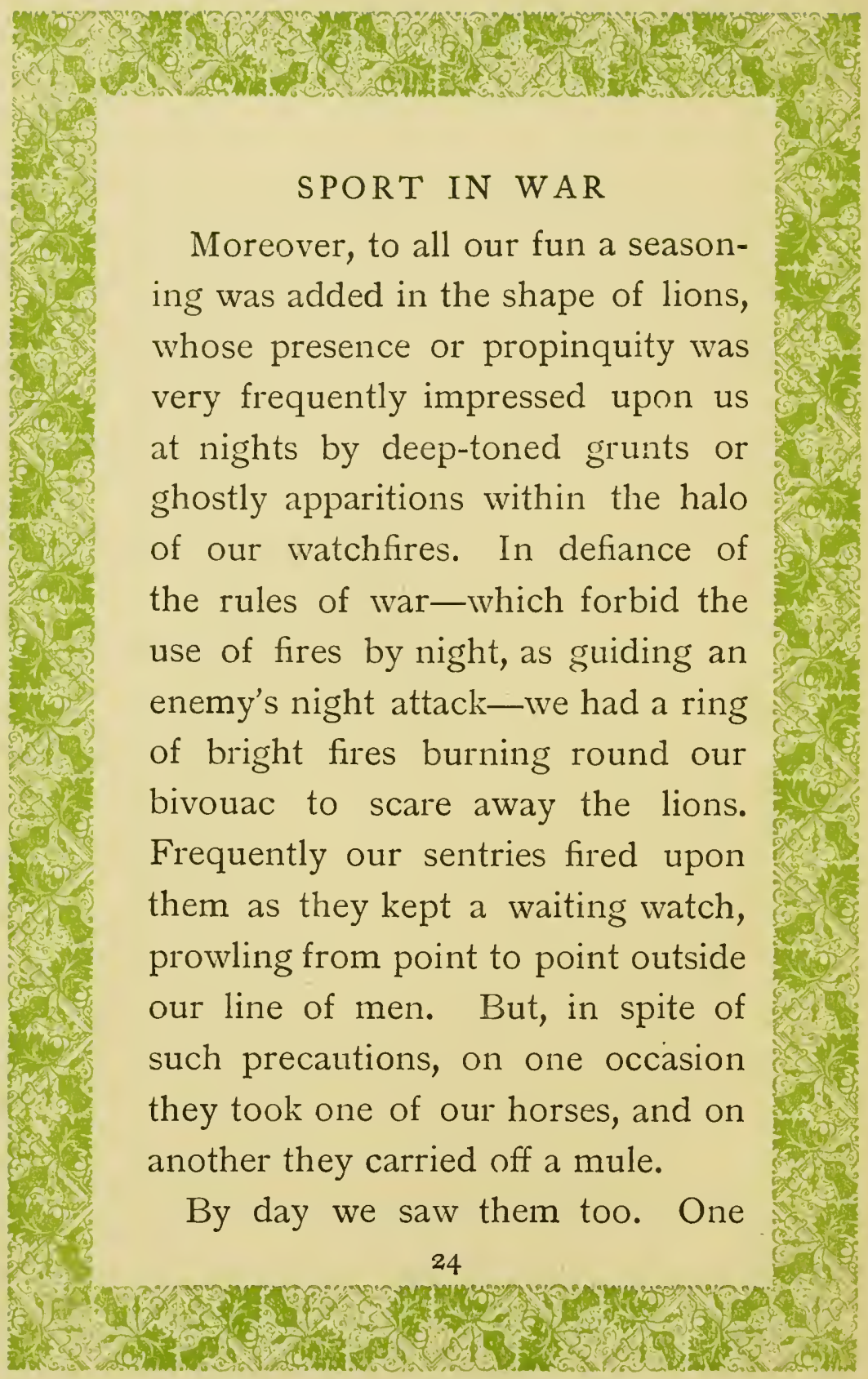




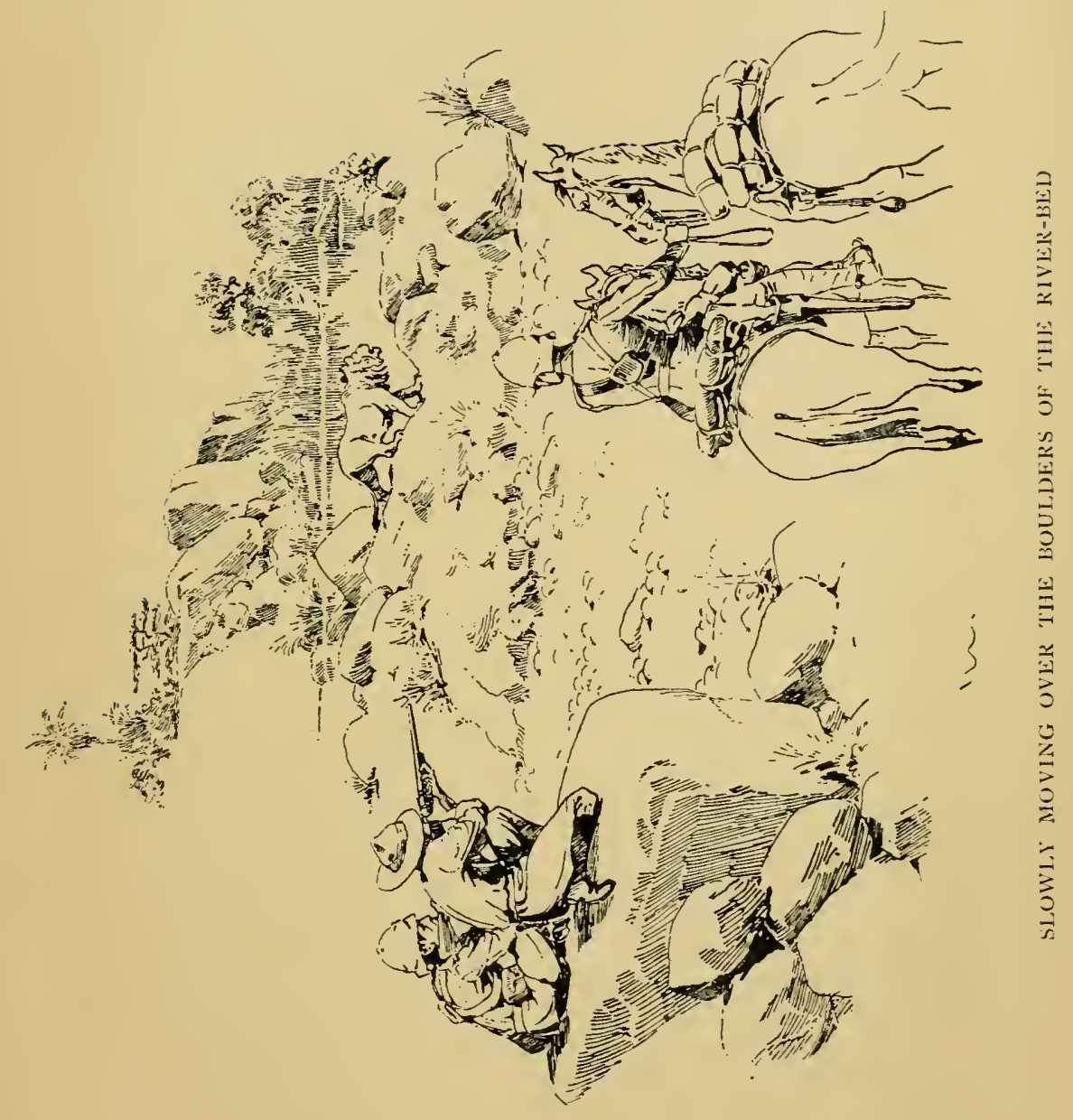





\section{SPORT IN WAR}

and disappeared from our view. Posting one man on a high point on the bank to watch the river-bed, and leaving the other in charge of our horses, the corporal and I made our way down to where we had last seen the lion. We were armed with LeeMetford carbines, and we turned on our magazines in order to have a good running fire available should our quarry demand it.

Meantime our main body, coming along the opposite bank of the river, had seen our manœuvre, and an officer and one man had come down into the river-bed from their side to help us.

Gradually and cautiously we surrounded the spot where we guessed the lion to be-cautiously, at least, 


\section{SPORT IN WAR}

as far as three of us were concerned; the fourth, the man who had come from the main body, was moving in a far freer and more confident manner than any of us could boast ; he clambered over the rocks and sprang with agility into the most likely corners for finding a wounded lion lying ambushed, and his sole weapon was his revolver-for he was a farrier. Such is Tommy Atkins ; whether it is the outcome of sheer pluck, or of ignorance, or of both combined, the fact remains that he will sail gaily in where danger lies, and as often as not sail gaily out again unharmed.

However, to continue : at last we were on the spot, but no lion was there-an occasional splash of blood, 


\section{SPORT IN WAR}

and here and there, where sand lay between the rocks, the impress of a mighty paw, showed that he had moved away after being hit. But soon all traces ceased, and though we searched for long we could find no further sign of him.

We halted on the river-bank during the intense heat of the day, and before resuming our march in the evening we sallied out once more to search the river-bed and an islet grown with bushes, where we hoped he might yet be. And while we searched the hussar, who had been assigned to me to hold my horse, and who was the man who, in the morning, had been posted to watch the river-bed, asked, "How many lions are there supposed to be here?" I told him 


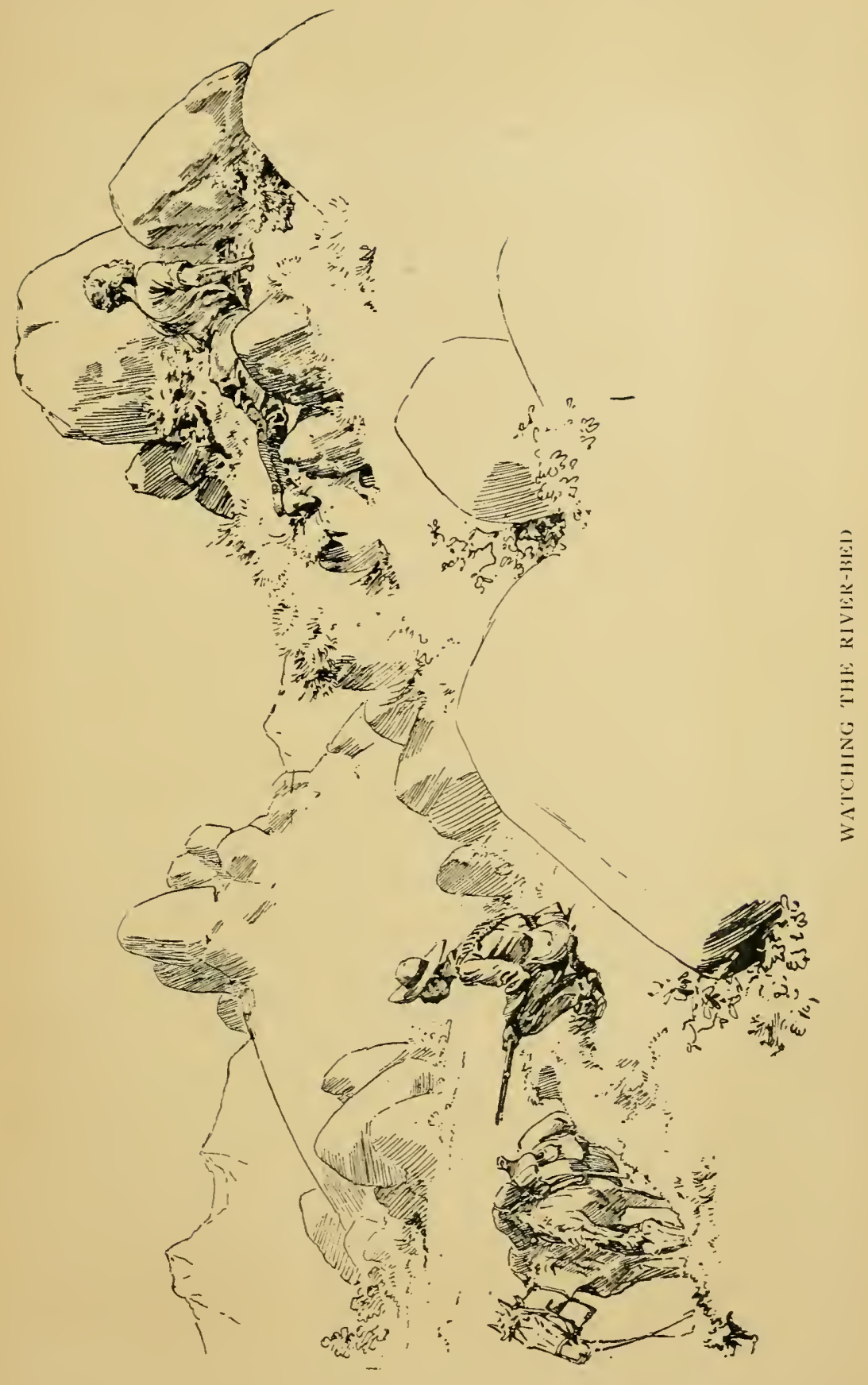





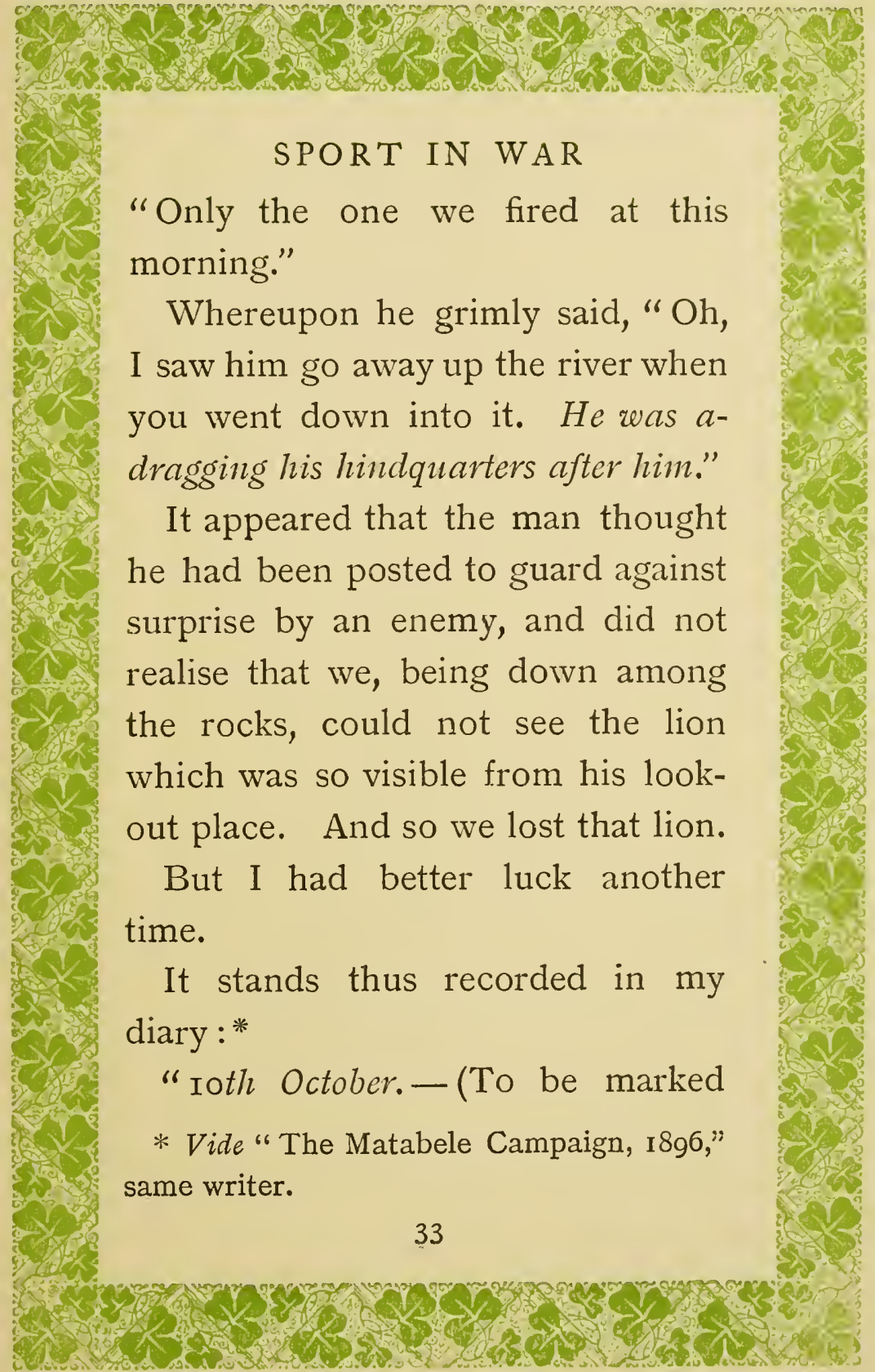




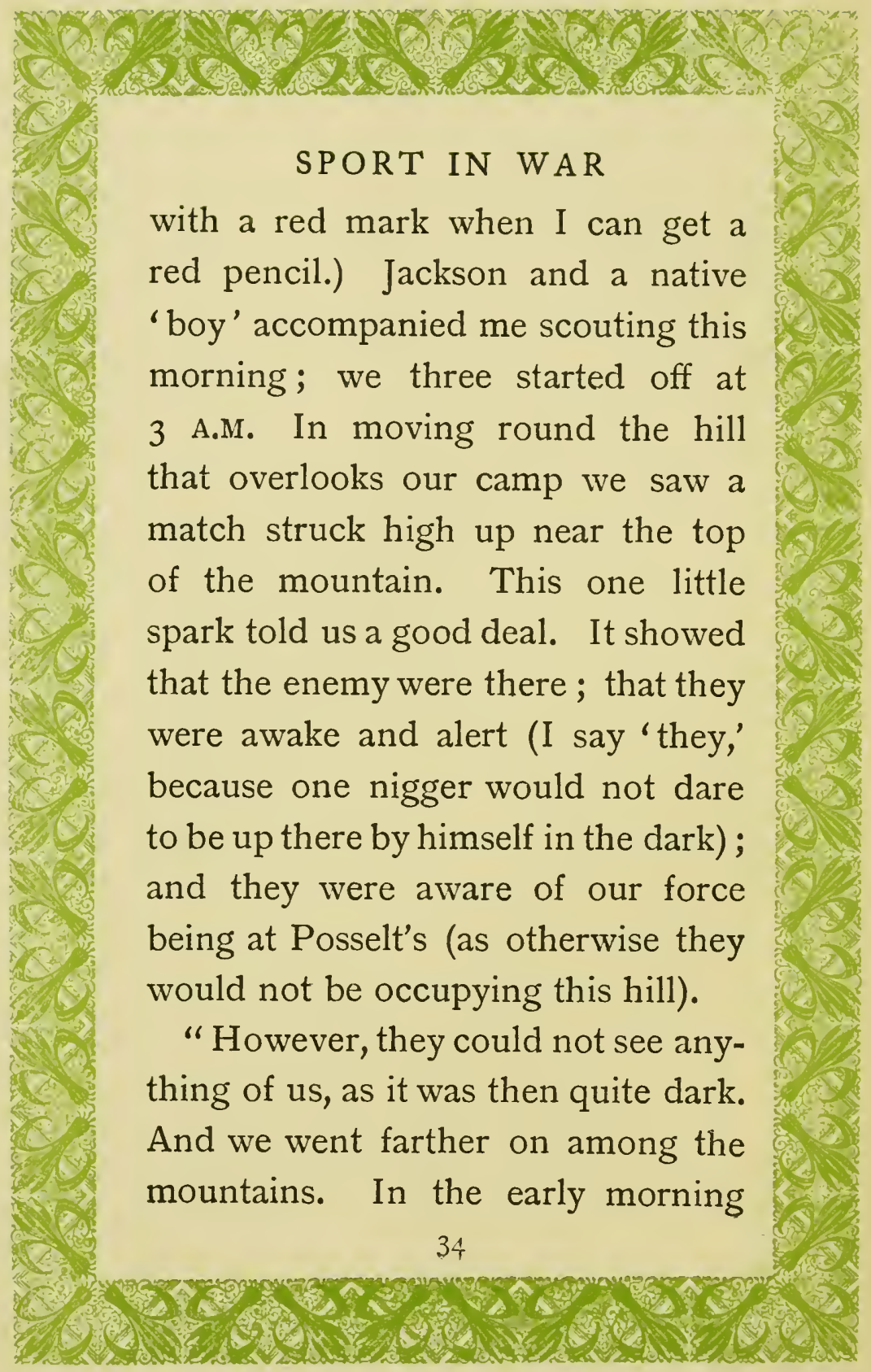




\section{SPORT IN WAR}

light we crossed the deep river-bed of the Umchingwe River, and, in doing so, noticed the fresh spoor of a lion in the sand. We went on and had agood look at the enemy's stronghold; and on our way back, as we approached this river-bed, agreed to go quietly, in case the lion should be moving about in it. On looking down over the bank, my heart jumped into my mouth when I saw a grand old brute just walking in behind a bush. Jackson did not see him, but was off his horse as quickly as I was, and ready with his gun : too ready, indeed, for the moment that the lion appeared, walking majestically out from behind the bush that had hidden him, Jackson fired hurriedly, striking the ground under his foot, and, as we 


\section{SPORT IN WAR}

afterwards discovered, knocking off one of his claws.

"The lion tossed up his shaggy head and looked at us in dignified surprise. Then I fired and hit him with a leaden bullet from the LeeMetford. He reeled, sprang round, and staggered a few paces, when Jackson, who was using a MartiniHenry, let him have one in the shoulder. This knocked him over sideways, and he turned about, growling savagely.

"I could scarcely believe that we had got a lion at last, but resolved to make sure of it ; so, telling Jackson not to fire unless it was necessary (for fear of spoiling the skin with the larger bullet of the Martini), I went down closer to the beast and fired a 


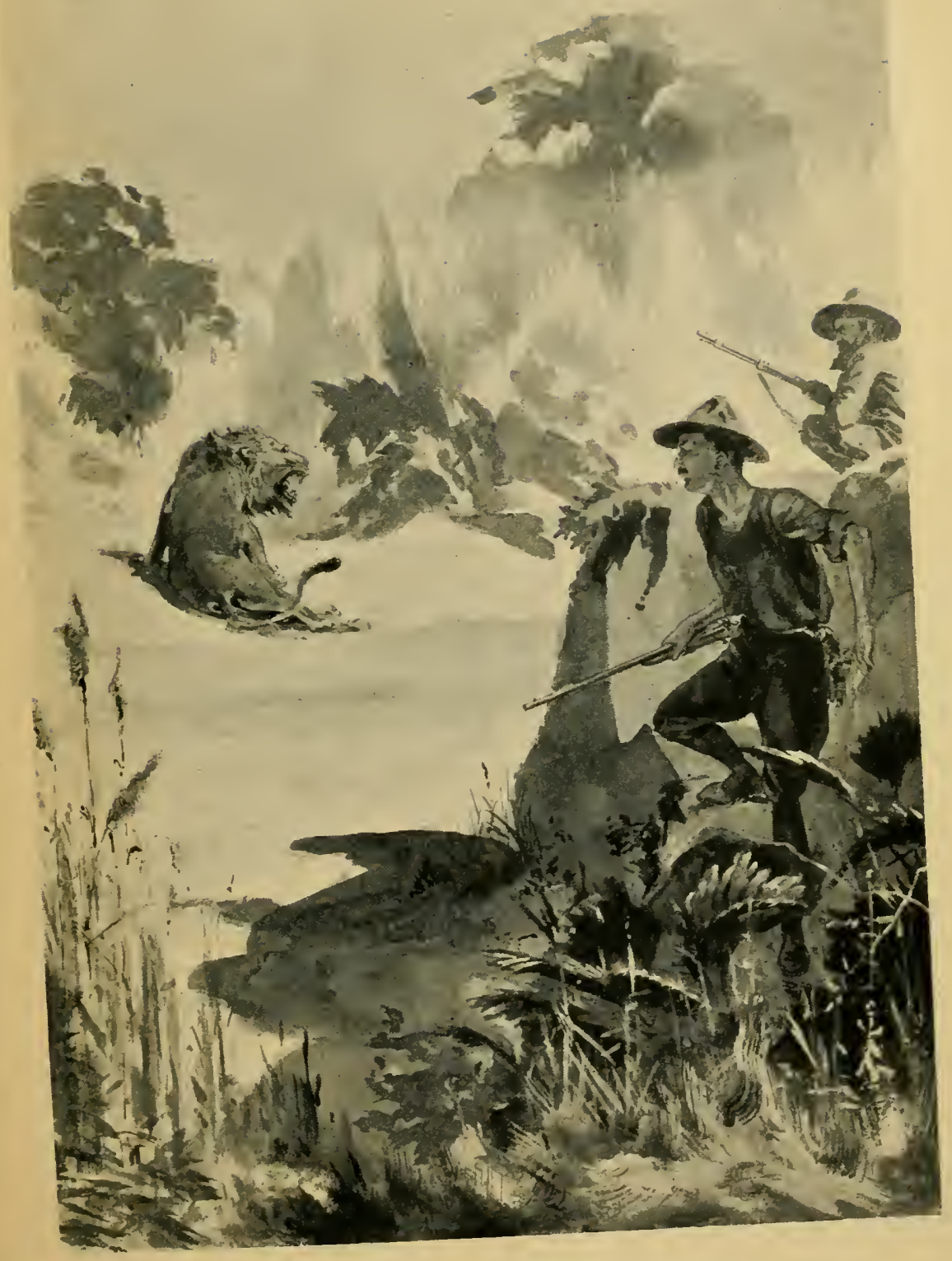

HE TURNED ABOUT, GROWLING SAVAGELY 



\section{SPORT IN WAR}

shot at the back of his neck as he turned his head momentarily away from me. The bullet went through his spine and came out through the lower jaw, killing him.

"We were pretty delighted at our success, but our nigger was mad with happiness, for a dead lion-provided he is not a man-eater-has many invaluable gifts for a Kaffir, in the shape of love-philtres, charms against disease or injury, and medicines that produce bravery. It was quite delightful to shake hands with the mighty paws of the dead lion, to pull at his magnificent tawny mane, and to look into his great, deep, yellow eyes. Then we set to work to skin him; two of us skinning while the other kept watch in case 


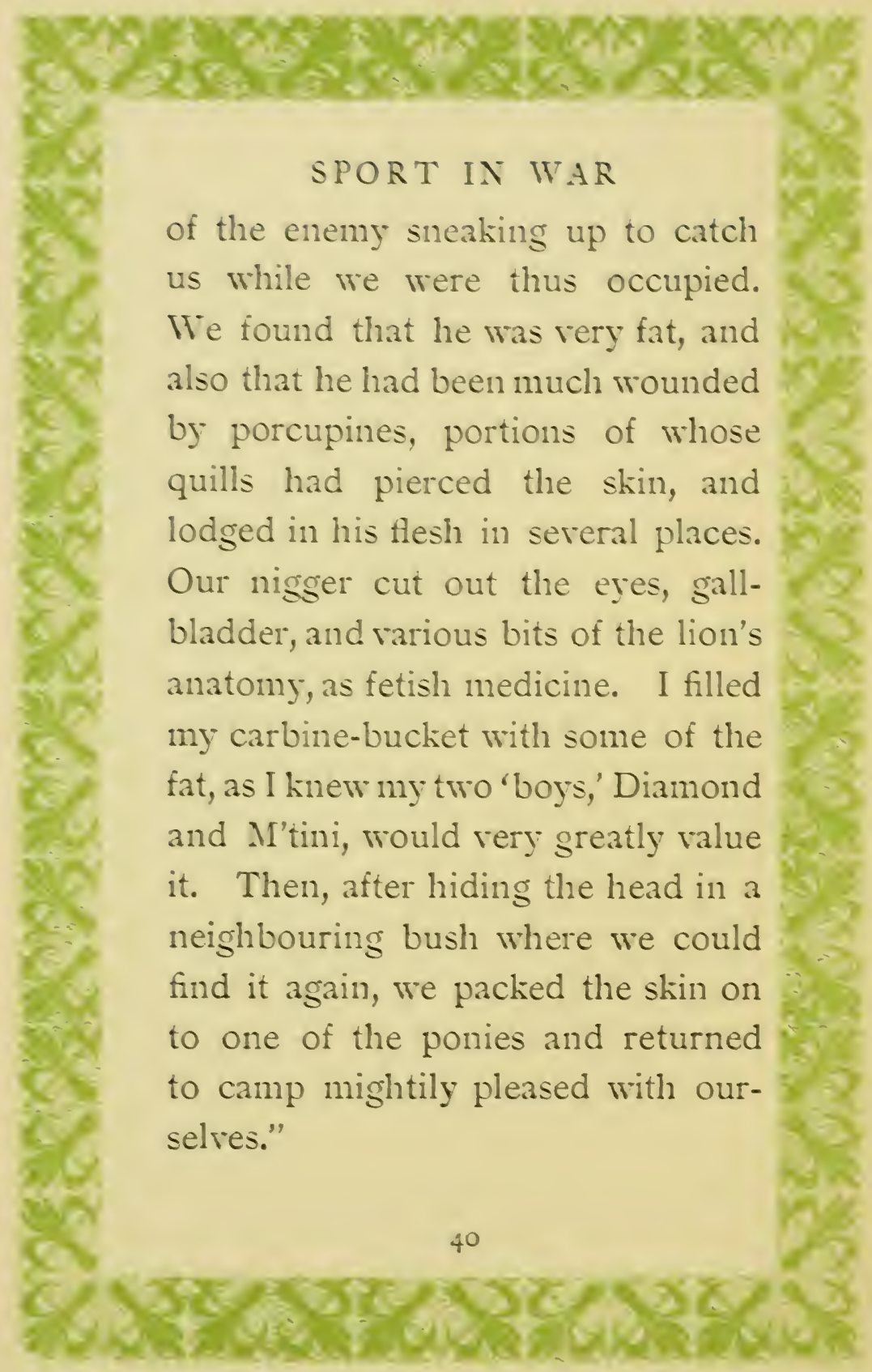




\section{A RUN WITH THE CAPE FOXHOUNDS}




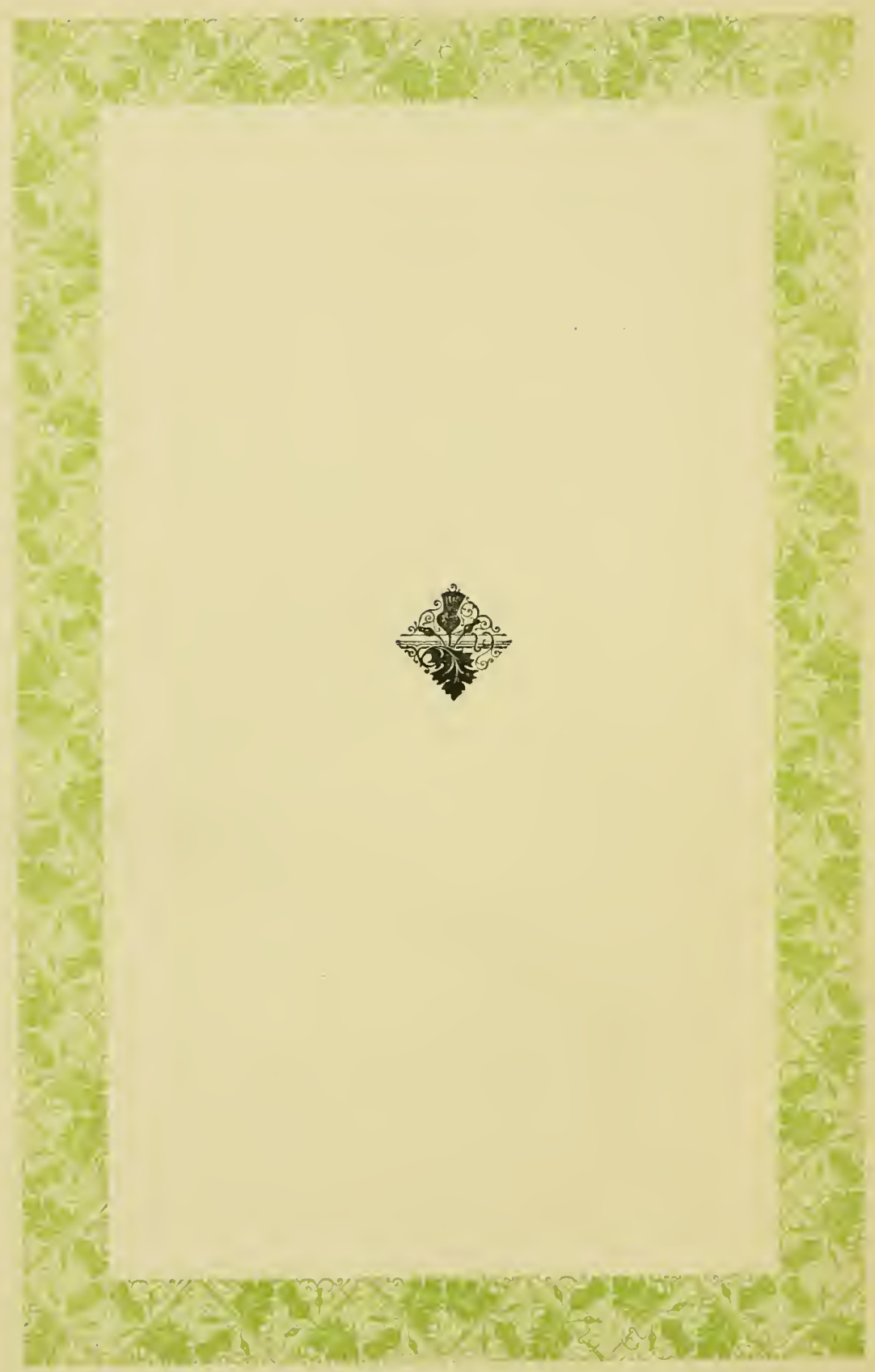




\section{A RUN WITH THE CAPE FOXHOUNDS}

withdrawing his broad
warm hand from off out by the evening train from the chill and darkling shadow of Table Mountain, and rattle off across the "Flats" for the hunting-ground beyond.

Our Colonial railway system may not be so speedy as those at home, but it is infinitely more advanced in 


\section{A RUN WITH THE}

one particular: its hunting rates for horses, hounds, and men are of the very lowest. Therefore, with blessings on a directorate so sporting, we seldom fail to largely patronise the rail for hunting meets. But tonight we are not many in the train ; besides the Master and myself (who act as whip) there are no members of the hunt aboard. To-morrow a new Governor is to arrive from England, and all the garrison must be there to see him safely in. But, in order that the farmers of the district may not miss their fun, a special dispensation from parade has been granted to the Master and. myself, and thus we find ourselves travelling forth to take up our night's quarters at Maasfontein, in readiness 


\section{CAPE FOXHOUNDS}

for daybreak hunting ere the dew has left the grass and the sun has parched the scent.

In less than an hour we have reached the lonely little station, and, after disembarking hounds and horses, we jog away in the gathering darkness over the two miles that separate us from the village. Our baggage we carry with us, as the custom of the country is, in saddlebags. In a hollow in the open downs we come upon the village, and as we pass its single, long, treeshaded street, the men and housewives peer out from their lamplit doors. We lodge both hounds and horses in the stables of the singlestoreyed village inn, and here we find a number of our hunting farmers 


\section{A RUN WITH THE}

who have come over in their waggons for the meet; for every Dutchman's waggon forms his travelling home for markets, meets, or fairs. And, while we tackle supper, they sit around and smoke, and talk of what the sport will be.

What quaint old fellows are these rugged bearded Dutchmen! Slow, well-nigh to denseness, outwardly, yet in reality full of sporting instinct, and also quick enough to see and to resent any display of English hauteur or attempt to patronise. They have simply to be treated as equals and as friends; the true freemasonry of sport will do the rest. It is a pleasure to see how their dull faces can light up and their whole demeanour change as they begin to 46 


\section{CAPE FOXHOUNDS}

talk on sport. After giving a hopeful view of prospects for the morrow, the conversation turns on other lines, and soon we are thrilled with vivid tales of bygone days when lions and tuskers formed the quarry in these same districts, where now we scarce can find a jackal.

But these sportsmen are not late sitters, and just as one is beginning to think whether it is quite good enough to hear another lion story at the risk of being asphyxiated with the reek of gin and Boer tobacco, they rise, and, with their hoarse "Goode-nachts," they clatter out into the darkness towards their several travelling bedrooms. Nor do we long outsit them, for, as the pig-sticking song says, 


\section{A RUN WITH THE}

To-morrow, by dawn, we must be on our ground.

After a final sup of whisky from our private stock, and a glance round the stable and the temporary kennel in the wash-house, we turn into our beds in the one bare empty room.

Our sleep is soon slept. The unrest natural to night before a hunting day, like John Peel's cry, soon "calls me from my bed," and I slip out and indulge in a glorious "tub" in the horse-trough in front of the inn. It is just daybreak, or, as the Dutchmen term it, "the light for seeing the horns of an ox"; a glow is in the sky behind the eastward hills, and on the village camp-ground the twinkling fires show that the farmers' 
CAPE FOXHOUNDS

"boys" are preparing the morning coffee.

An hour later this same campground, or "uitspan," as it is called, is the scene of our meet.

The farmers soon join us, mounted on their wiry unkempt little horses, their rusty bits and stirrups being as unlike the turn-out of the English hunting-field as are the riders' corduroy trousers, hobnailed boots, and wide flapping hats. But, dirty and ragged though they be, the horses are both clever and quick in bad ground, and wiry and enduring to an extent that would hardly be expected from their narrow chests and quarters; while the riders, stolid and grumpy as is their demeanour, will rouse up like schoolboys and go 


\section{A RUN WITH THE}

with the keenest when once there is fox afoot.

Cups of coffee from the ox-dung camp-fires are passed around, and then the everlasting pipes come out and are filled by the simple method of plunging them into the capacious coat-pocket, which is kept filled with loose "Boer" tobacco. The strong aroma hangs as heavily as its blue smoke on the raw morning air, and promises a fine scenting morning as we trot away from the uitspan towards our hunting-ground.

Our hounds would perhaps look strange at home-their best admirer could scarcely call them a level lot; but this need not be wondered at when it is remembered that we have to take what we can get from kind- 


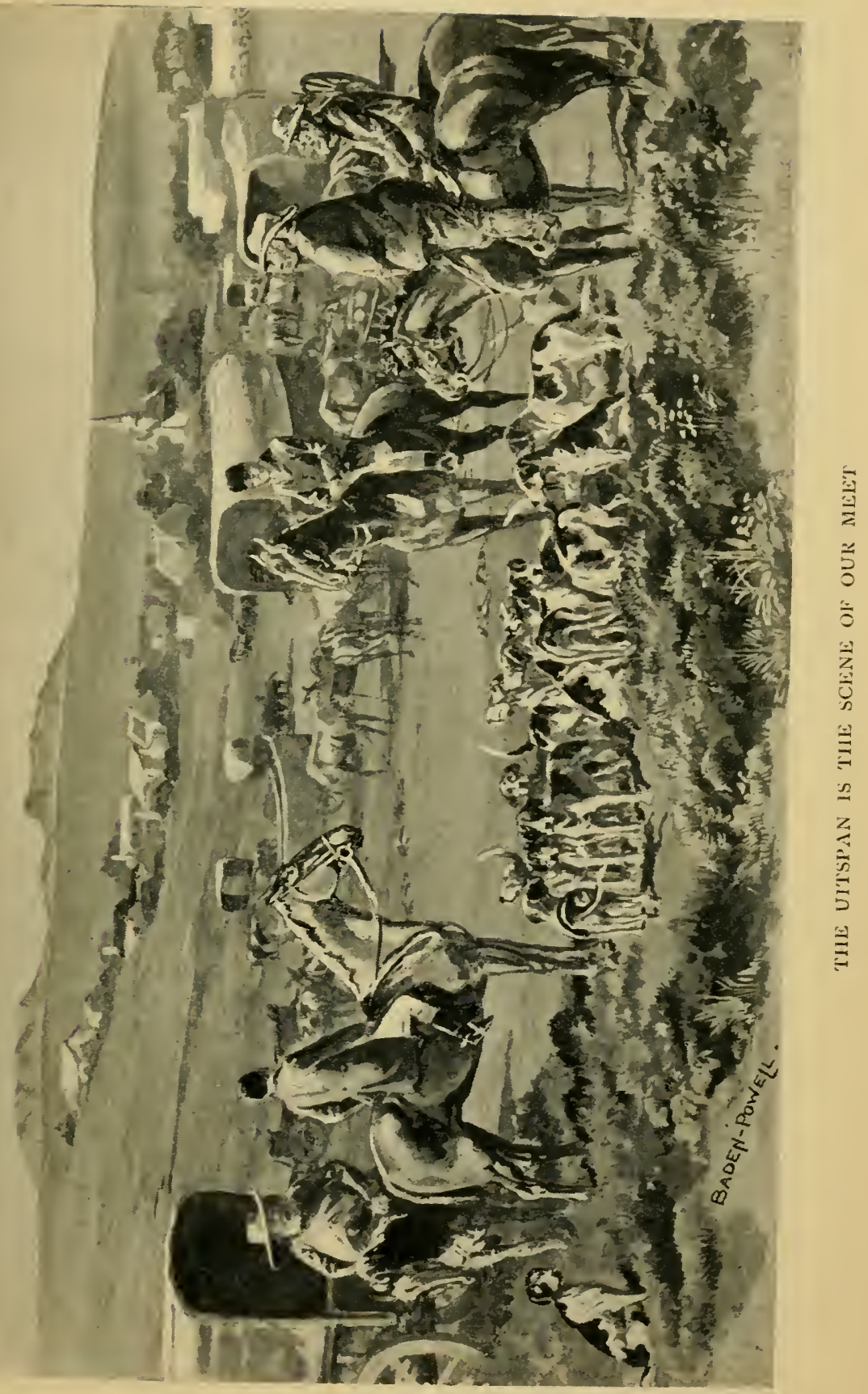





\section{CAPE FOXHOUNDS}

hearted Masters all over England. The fatal "dog-sickness" of South Africa plays such havoc in the course of a season as to necessitate a fresh draft from home everyyear. Shipping charges are very high, and the funds of the hunt are per contra very low, so it is not surprising that our pack is a somewhat mixed one. But, although "a rum 'un to look at," it is a "good 'un to go," and every hound in it, this fine hunting morning, looks hard and fit for anything.

At their head rides our Master, as fine a specimen of the British soldiersportsman as you would meet in a day's march. (Poor Turner! he gave up the hounds not long after the day I am here describing, and he now lies buried on the banks of 


\section{A RUN WITH THE}

the Sabi, away there beyond Mashonaland.)

Beside myself rides George, our whip, a Cape lad of nondescript breed, but especially useful in our hunting-field from his proficiency in the art of "spooring" or tracking the jackal over the frequent sand patches, which do not carry scent.

As we rise the hill above the village the neighbouring country unfolds itself before us in a succession of undulations of grass and fallow land and occasional patches of low scrub and heather. There are no fences beyond occasional boundary banks, drainage ditches, and dry watercourses. Away to the east and north the downs run up into mountains, while to the westward lie the 


\section{CAPE FOXHOUNDS}

"Flats," sandy heath-covered plains, some eight miles in extent, with the grey-blue mass of Table Mountain rising stark and sheer from out the sea beyond them.

Look where you will-except for two or three widely distant clumps of trees, with their white farmbuildings among them-there is little to show that the country is a populous colony. Most of the farms and villages, being built near water, lie hidden in the folds of the ground.

The long, broad shadows cast by the rising sun across the dewy downs are slowly growing shorter as we jog along towards the dark heath-grown hillside that is our first cover. But ere we reach it a fresh delay occurs. Over the brow before us there rise 


\section{'A RUN WITH THE}

first the white tilt and then the nodding horses of a "Cape cart" trotting fast to meet us. Within it is De Villiers, or, as the rest pronounce it, "Filjee," a sporting-hearted farmer, who, although he does not ride himself, loves to see others do it boldly if not well, and to that end he never fails to bring a good supply of "jumping powder" and other similar aids to horsemanship.

In the present case this diversion is particularly conducive to sport, as it serves to keep our usually overenergetic field well occupied while hounds are drawing cover. The Master waves them in, and George and I take up our places at opposite corners to view the fox away. From where I stand below the crest I see 


\section{CAPE FOXHOUNDS}

but little of the cover and of hounds at work within it, but other entertainment comes to me. Anon there is the slightest rustle in the bush, and stealthily a hare slips out and squats quite motionless a few yards from me; she hearkens backward, her great dark eyes bright-glistening in the sunlight; then she turns and hunches in again, but a minute later the Master's cheering voice again sends her palpitating on to the open ; a moment's pause, and then away she lits adown the slope and scampers off to other hiding-places. Now creeping up towards me, close along the heather's edge, there comes a string of brown-grey partridges all scuttling fast in frightened hurry. I wonder who gives them their orders? 


\section{A RUN WITH THE}

They act upon them instantaneously. "Halt!" they all crouch. "Heads up !" "Fly!" Whirr ! and the whole brown covey are off together down across the ravine ; then, with stiffened wings, they rise the other slope: a sudden wheel, then slide up and up the grassy shoulder without a single flutter till they overtop-

Hark-a whimper! No - yesanother! Followed by the anxious cry of others owning to it.

"Tally-ho! Gone away!" screeches George at the bottom corner.

With a horse like my old "Toulon," who knows his business, my shortest way is smack through the cover. So into it we go ; plunging here, jumping there, through the heavy heath $5^{8}$ 


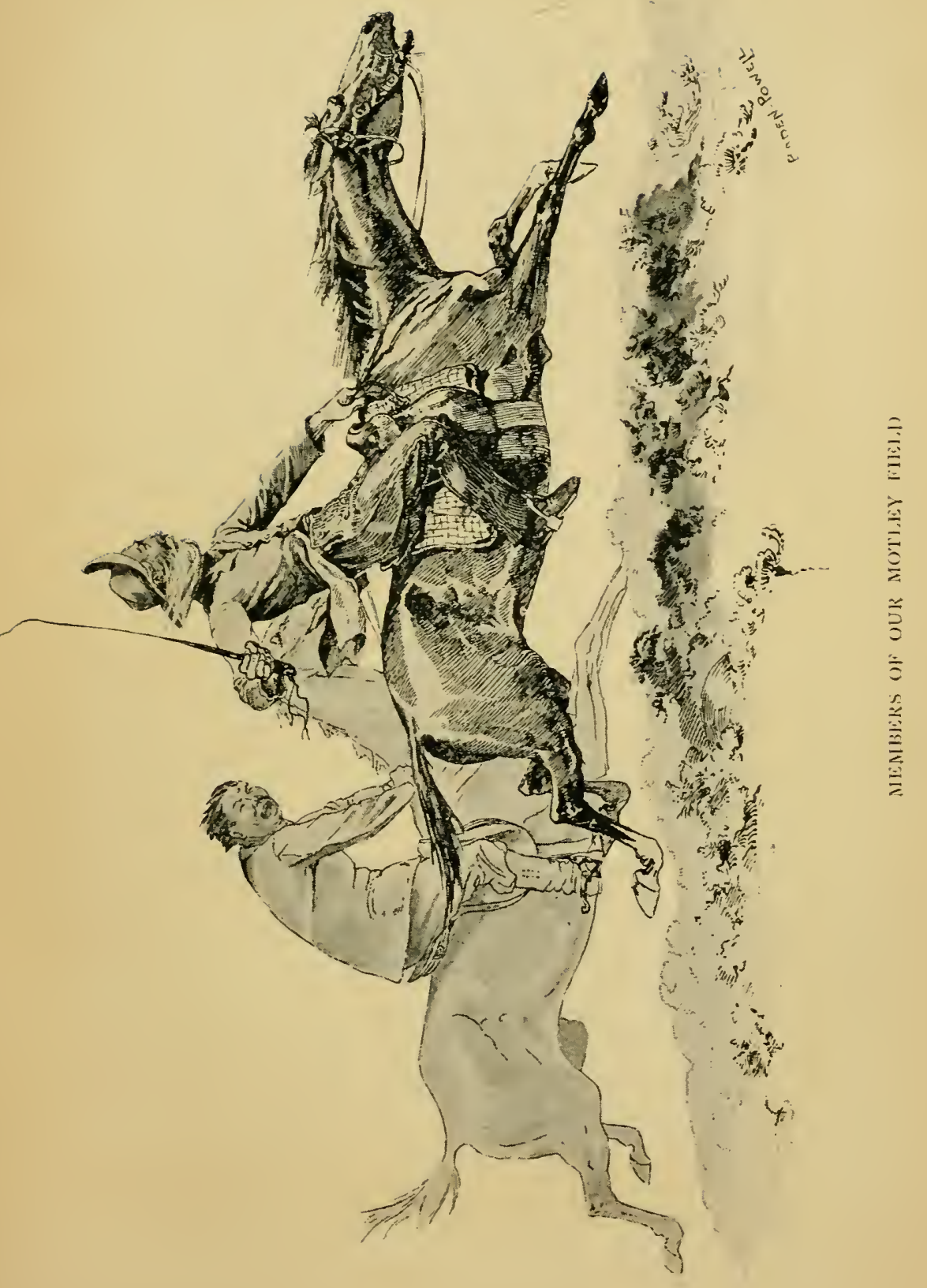





\section{CAPE FOXHOUNDS}

and scrub. As we come over the hill-top the fun is spread before us. Just in time we are to view him cross the ridge in front-a fine old fox, looking somewhat like the little rover of Old England, but, being longer in the leg, he does not stretch himself so close along the ground.

Hounds in cheery chorus are stretching after him, gleaming white and mottled on the green grass slope. And George, not far behind them, in his pink and leathers, riding a bright bay gelding, completes a hunting picture of the brightest colouring, that in the instant photographs itself upon the mind.

And now the Master is through the brook-bog in the bottom, and in our turn we scramble through, bringing 


\section{A RUiN WITH THE}

on the last tail hounds from out the cover. Then, while we breast the slope, a backward glance shows all our motley field are tearing down to follow us. Now we top the rise and find an open stretch before us; scent is good, and hounds are racing well together. 'Tis grand to gallop thus over such good ground, with hounds lying well away before us, and the field coming equally well behind; while the keen morning air, lightening up the lungs to the extremity of buoyancy, gives one a taste of life that is divine.

The going is chiefly rough, long grass, whose only fault is treachery, in the shape of "ant-bear holes." These are the burrows of the anteater, more commonly known as the 


\section{CAPE FOXHOUNDS}

ant-bear or ardvark (" earth-hog"). Luckily, they are not in this district so plentiful as in Natal and Zululand; and yet one hole is quite enough to spoil your hunting for the day, if not for ever. The ant-heaps, too, are obstacles, but honest ones, because they are not invisible. But on we fly, as though such things existed not, and the pace is good enough to take us clean away from all our following; but, luckily for them, before we've had two miles of this most glorious burst, a cowboy heads the fox. He turns his line and takes adown a valley to our left, and here he finds a thick and scrubby cover from which lead many blind ravines. A check, while hounds endeavour to worry out the line, gives pause for 


\section{A RUN WITH THE}

the field to come bustling up. Then some dismount to ease their blowing nags, while others ride around to help, as they suppose, the nonplussed hounds. Their noisy babel, as they talk about the run and chaff late-comers, would annoy one were it not so ludicrous to see how much a gallop moves these Dutchmen from their cold stolidity.

Now one young hand, supposing all is over, off-saddles, as his custom is, and leaves his horse to roll; but at that moment hounds once more hit off the line, and helter-skelter, off we pelt, leaving this young man to gain experience. Onward down the long hillside we press, now bending right, now swinging left, but ever edging on towards the "Flats." A 


\section{CAPE FOXHOUNDS}

ditch and boundary bank next cause some grief, and farther on an ugly dry ravine brings down the Master and turns a large proportion of the field to seek another way.

Hounds now are tailing off a bit. Young Ranger leads the rest, as is his wont, by quite a hundred yards: he's far too fast, but we cannot well afford to trim our pack, else might we well dispense with Colleen, tooa small dark bitch, whose only place is at the Master's heels; and even when he's down, she waits to see him safely up again.

Our fox now runs us through a farmstead, where, among the cattlekraals, we get some stone-wall lepping. At length we reach the tract of heath and dunes that forms the 


\section{A RUN WITH THE}

"Flats," and scent falls light and catchy. Slow hunting here becomes the order of the day, with now and then a sudden burst along some grassy bottom. The field, though much reduced in numbers, is more than ever keen, and follows closetoo close-upon the hounds.

"Now, Wanderer, my lad, what is it? Lame?" No, worse! Ay, poor old hound, he leaves the line, with drooping head and stern, and walks aside, just glancing up, as if to say, "Don't mind me, old friend, go on and see it out"; and he flings himself, quite helpless, down behind a bush. A little Kaffir tending cows close by agrees to nurse him, and, if he lives, to bring him home; but the hunt will never see old Wanderes 


\section{CAPE FOXHOUNDS}

again. Dog-sickness always for its victims seems to take the best.

With sorrow at my heart, I push along to overtake the bobbing crowd in front, and find them checked beside a stretch of open sand. Here all scent fails, and George, on foot, is taking up the spoor, hounds following in an interested group. Upon the sand the tracks show where the fox has stopped to listen and then has doubled on his trail. Into the bush once more, andTally-ho !-he jumps up right before us. What a screech of men and hounds! Old Piet Nielmann rushes past me, lambasting his fully-blown horse with a heavy sjambok, till a sturdy tussock stretches both the rider and his horse upon the sand. 


\section{A RUN WITH THE}

The crowd go racing on. Over yonder rise our fox is viewed; a minute later we are there, and see the fun below. He doubles in some grass, and round the beauties come, just like a flock of pigeons wheeling - a crash, a snarl, and they roll him over in the bottom. Whowhoop!

And while he is broken up in the good old way, the knot of panting men and horses is gradually added to by stragglers coming up to join the chatter and the talk about the run.

Then pipes are lit, and, in the best of moods, we make our way once more towards the upland, where the farm of "Filjee" stands out white upon the hillside, bare except for this one group of trees and build68 


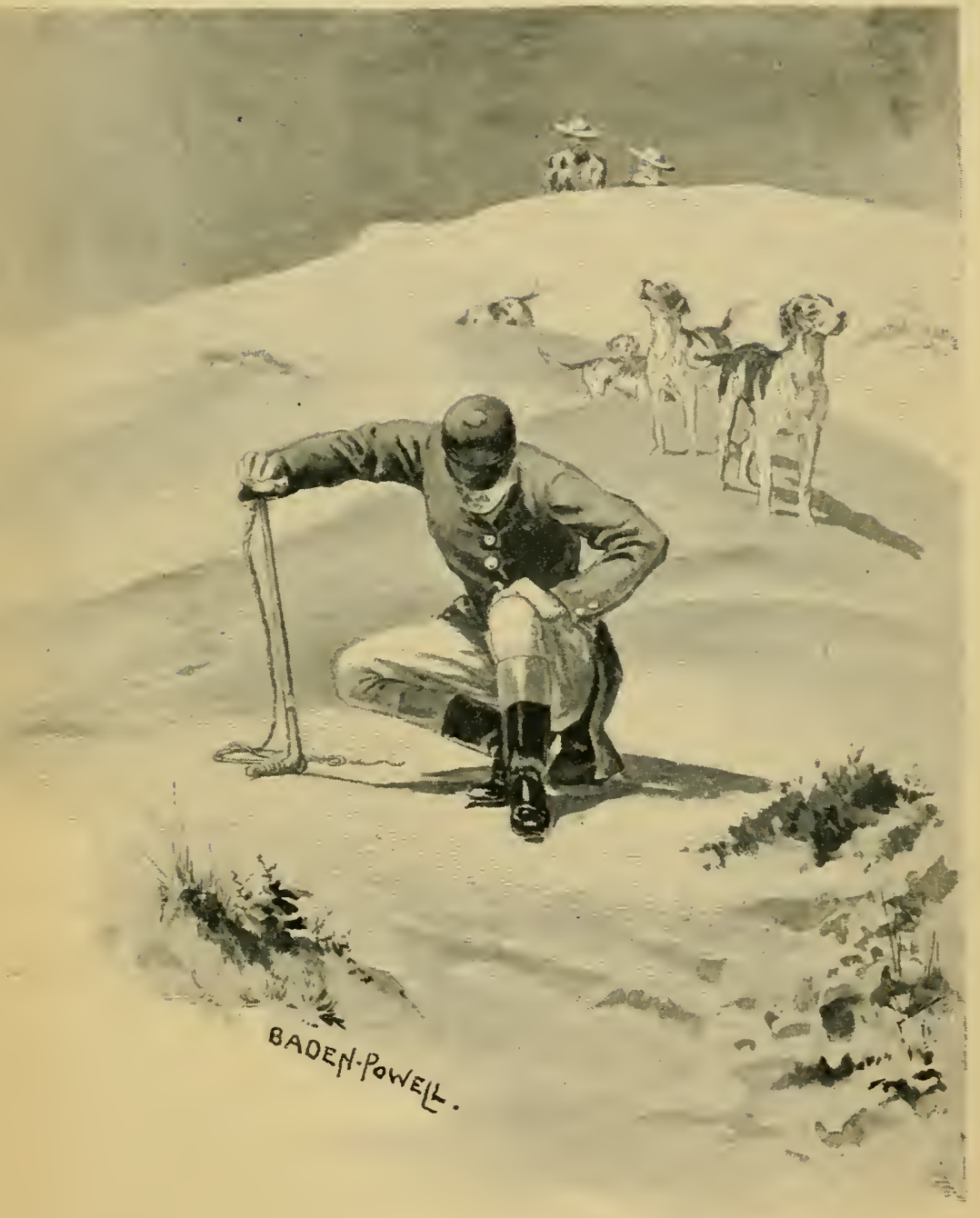

GEORGE AC'TING AS LEADING HOUND 



\section{CAPE FOXHOUNDS}

ings. On drawing near we find a plain-faced single-storeyed house, with windows blinded by a formal row of pollard-trees set close in front. Upon the stoep or terrace-step, De Villiers and his frau receive us. Within the steamy room (whose windows never open) we find a plentiful repast laid out, of beef, black bread, and succotash, backed by an imposing display of bottles holding "square-face" gin, pontac, and van-der-Hum. But little time is lost in reconnoitring this formidable array, and our hungry sportsmen spring to the attack as hounds from leash. Once at it, they are fixed. Still, we know the scent which has favoured us so far may not last all day, so, after a welcome snack and a 


\section{A RUN WITH THE}

toast to our sporting entertainer, a few of us move out to go afield again. But not so the majority: with them the lunch is half the hunt: they feel they've had their run, and now enjoy its complement.

So as we jog away to covers higher in the hills, we find our field reduced to three, and those three not likely, with their overweighted mounts, to carry on for long if the run has any pace. At the cross a spruit running out of a little bushy glen, hounds suddenly break and feather on a trail, and, bustling up the ravine, they pick up a gradually improving scent. Forrard! Forrard! On to a long swelling down we go, over the level for a space, and then a heavy breather up to the top; those 


\section{CAPE FOXHOUNDS}

whose mounts are well shouldered have the best of it striding down the further slope. Through a network of dry watercourses, where the scent falls light, they hit it off on a grand level plateau beyond. Then we get a real good ding-dong gallop that soon polishes off our little field, and leaves us three alone to follow hounds, while praying that we too may not get left. The line has led us straight, without a swerve, towards a conical hill, whose pointed heathclad top has often served us for a landmark; and hounds are tailing out a bit on the lower slopes as the line takes us round its base. Now Ranger, who is far ahead, swerves suddenly, then circles round, the others cast about. A check at last ! 


\section{A RUN WITH THE}

the first in thirty minutes. Ranter has it! but for a moment only; he brings it up a watercourse, and there's the earth before us in an overhanging bank.

It should be an easy one to dig, "had we but weapons handy." And so they are. Over the next rise there peeps some trees-the trees of Swartzkop Farm. George canters off, and soon is back with pick and spade. We link our three horses all together with their reins, and, while George and I proceed to dig, the Master holds the pack away.

Quick work we are making with the bank when, without a moment's warning, through a cloud of dust between us, there springs out the great red "Jack," and flies away before 74 


\section{CAPE FOXHOUNDS}

the very noses of the pack. For one short instant they scarce realise the case, but then they swoop upon the line with a screaming chorus that would wake the dead. Indeed, it wakes something more important than the dead: it causes our horses to throw up their heads, and, without a moment's hesitation, to start in pursuit, in no little gaiety of heart at finding themselves without the usual burden of their riders. Helplessly we, in our turn, start to follow; but they are streaming away over the shoulder before us, while we, pounding in our top-boots through heavy grass and heather, find ourselves well pumped within a hundred yards. The hounds are gone, the horses top the sky-line, still tied head 


\section{A RUN WITH THE}

to head, but galloping with all their might; they disappear, and after them, more faithful to the Master's horse than Master, there goes Colleen. They're gone! We pause, and, blowing hard, we make a few appropriate remarks. And then we turn to climb the peak in hopes, at least, of seeing how the hunt may end. We struggle up and clamber, none the better for our boots and spurs and feverish haste. Anon we pause for breath, when lo, behind us, the fox is pounding heavily up the hill ! He has completely circled round it, and again is making for the earths that lie beside us. But close upon his brush there follows Ranger, ever to the fore, with all the ruck not many yards behind. Now Ranger's 


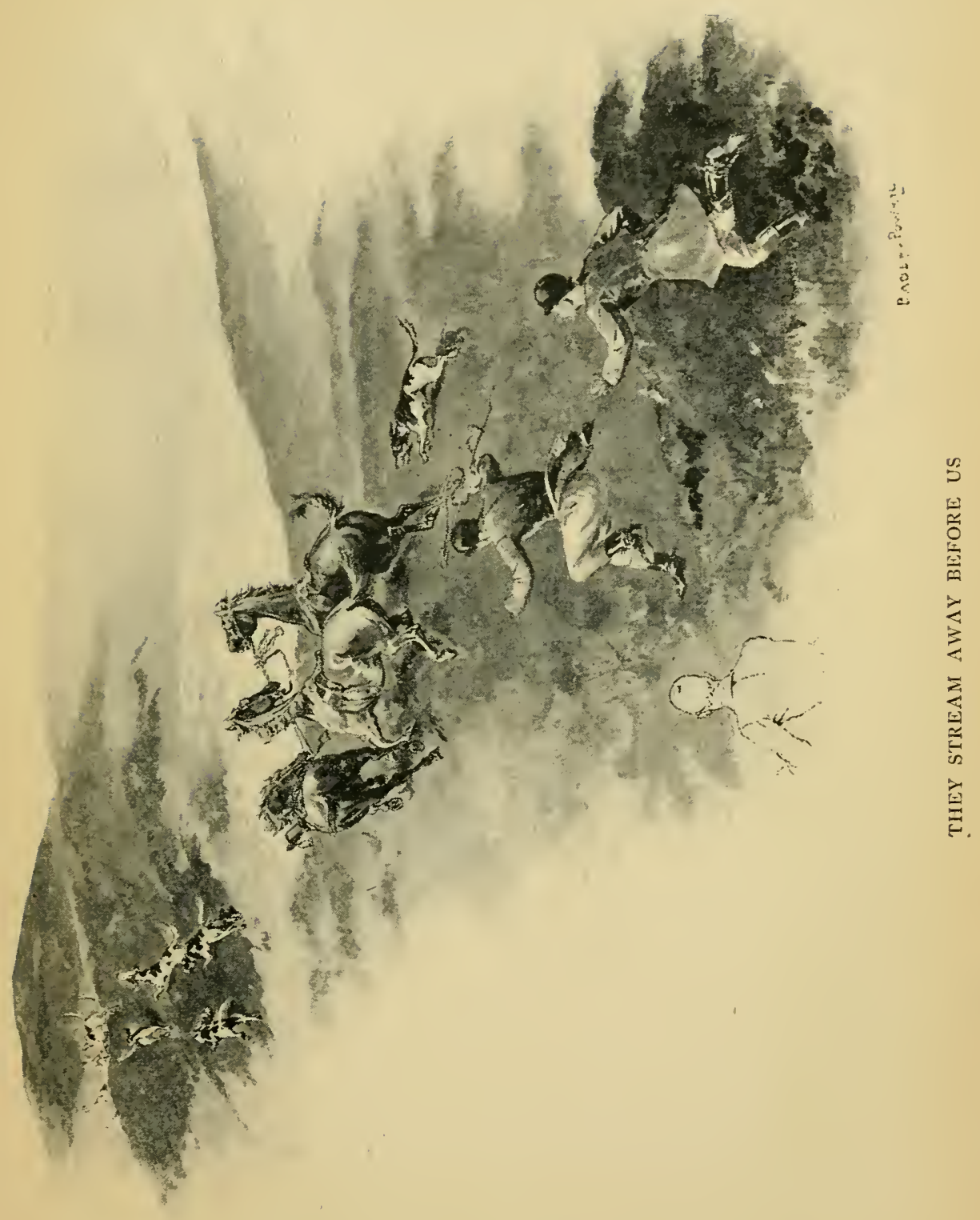




\section{,}




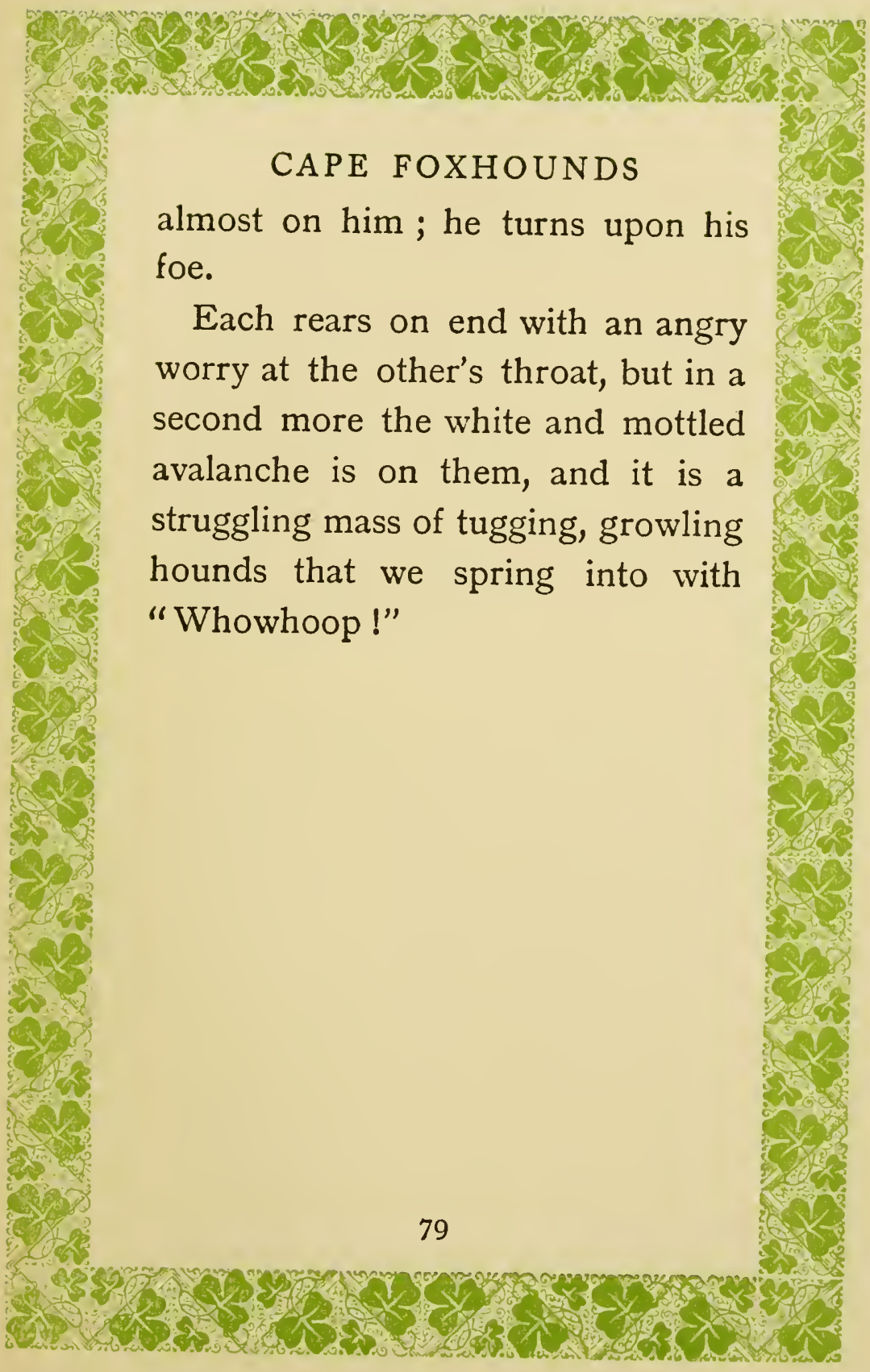




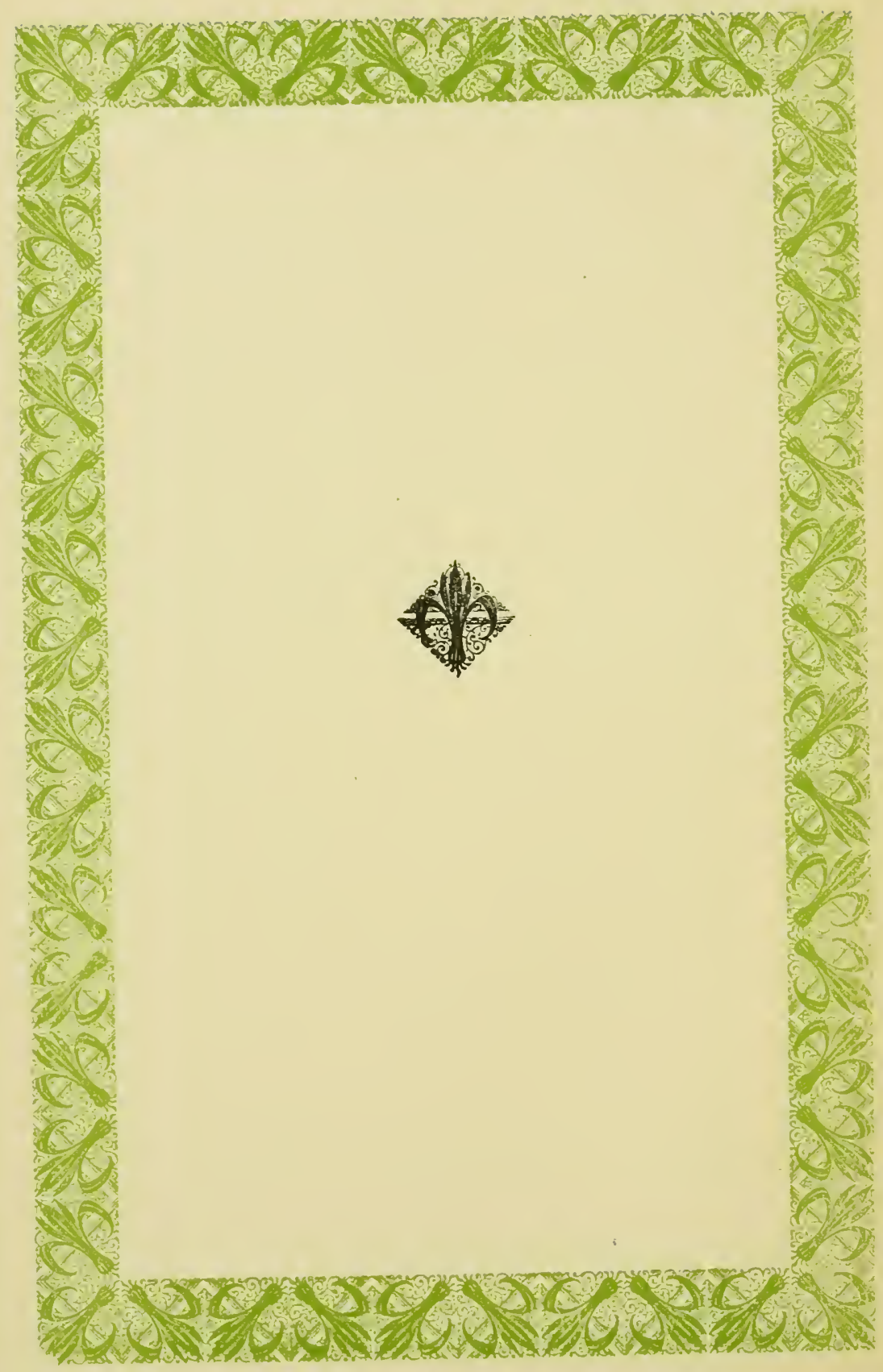




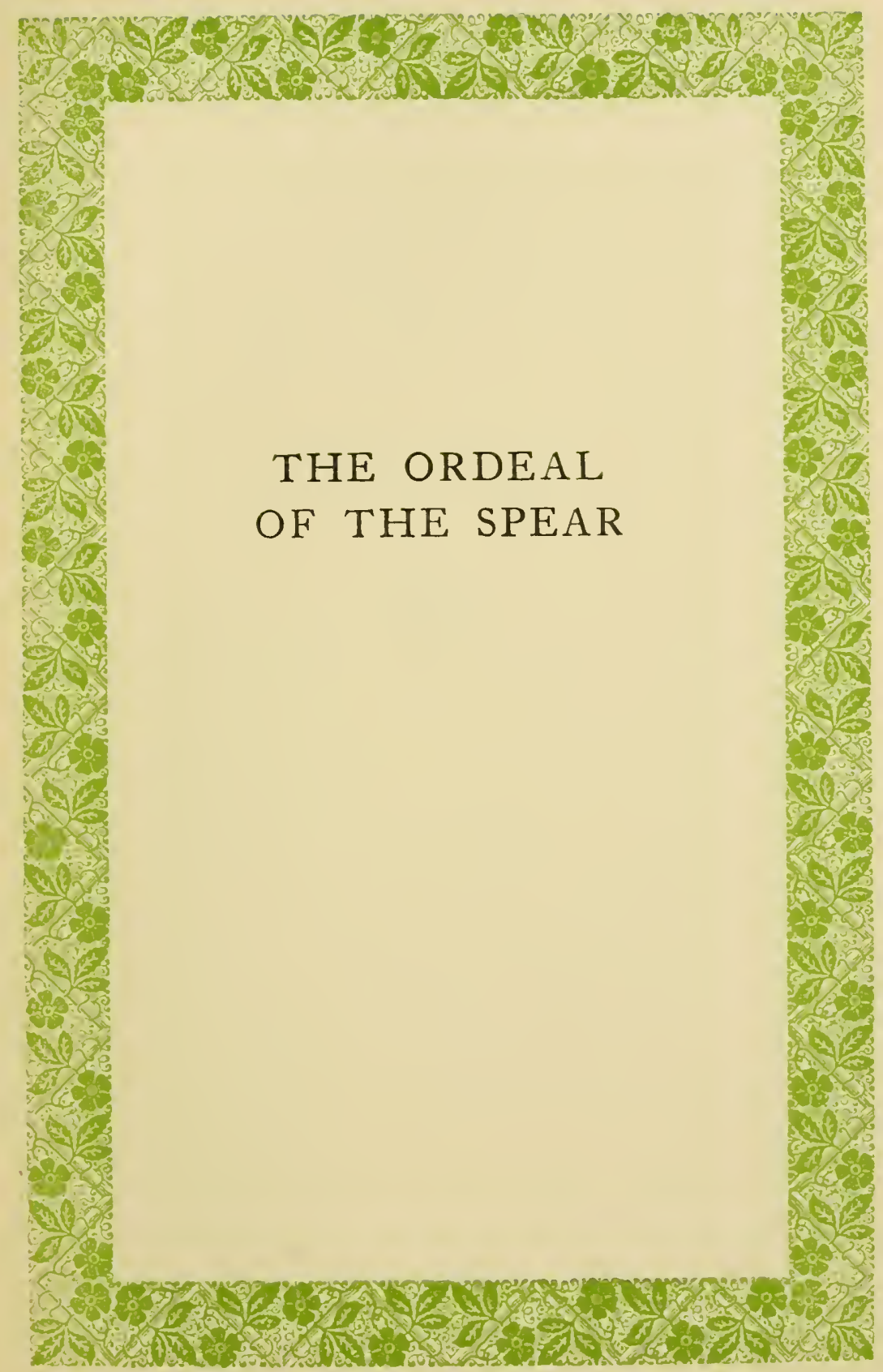




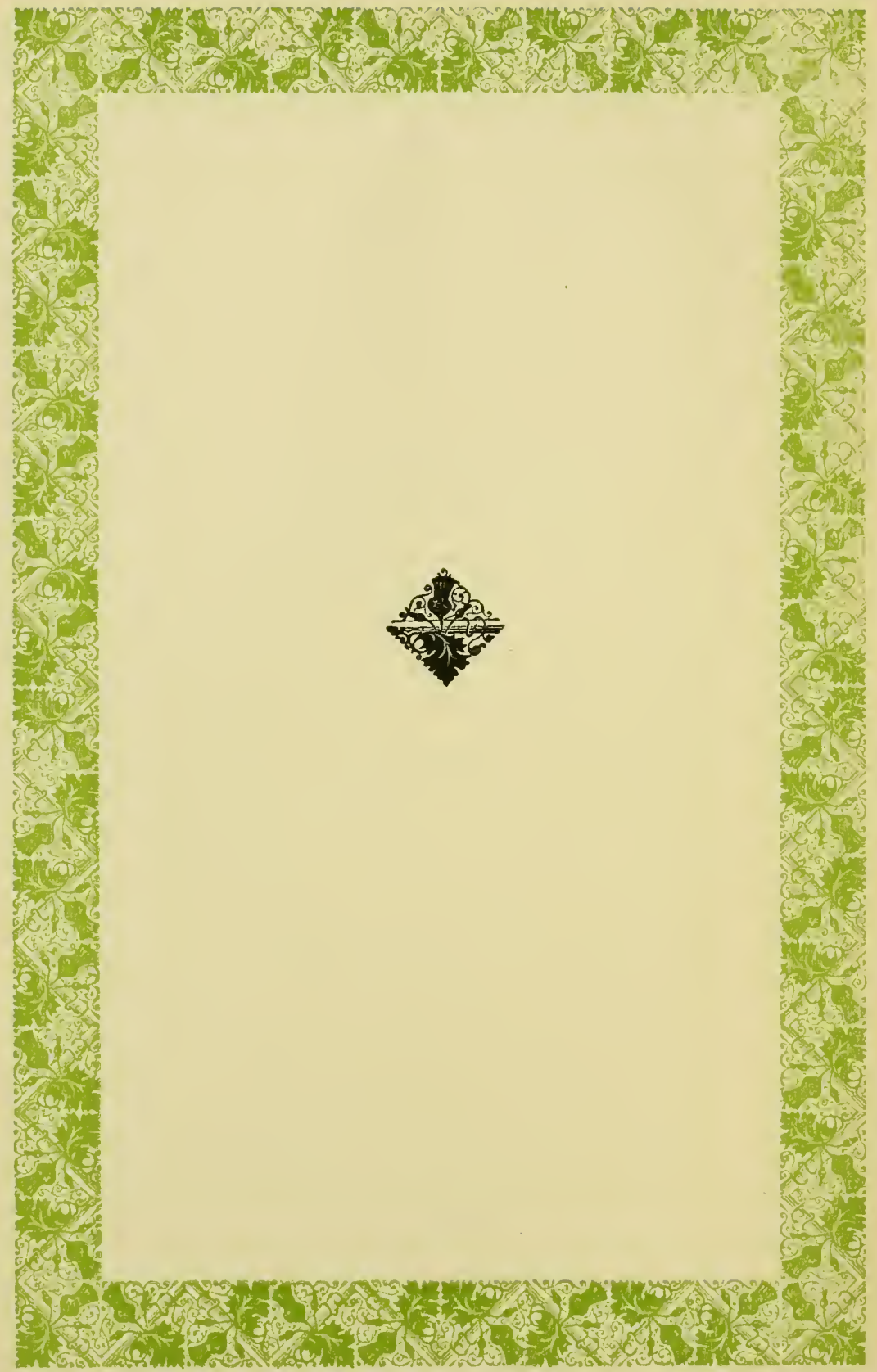




\section{THE ORDEAL \\ OF THE SPEAR}

(2) deep shade of a
Meerut Kadir, a camp Christmas pig-sticking meet. Among some adjoining trees a few more tents formed the temporary home of some ladies who had come out to the jungle to witness the sport.

Among these were Edna Clay and her mother.

(Had they been English people 83 


\section{THE ORDEAL}

I should possibly have referred to them in the reverse order; but with Americans the relative importance of the members of a family is, as a rule, in an inverse ratio to that which obtains in England. The American fathers and brothers come at the back-end of the list, while the daughter of the house leads at the head.)

The Clays had been wintering in Meerut, where the good climate and the social cheeriness of the large military station contributed to make it an agreeable substitute for the usual Continental watering-places that form the habitat of Americans blizzarded out of their own country.

Having many friends among the 6th Hussars at Meerut, the ladies had 


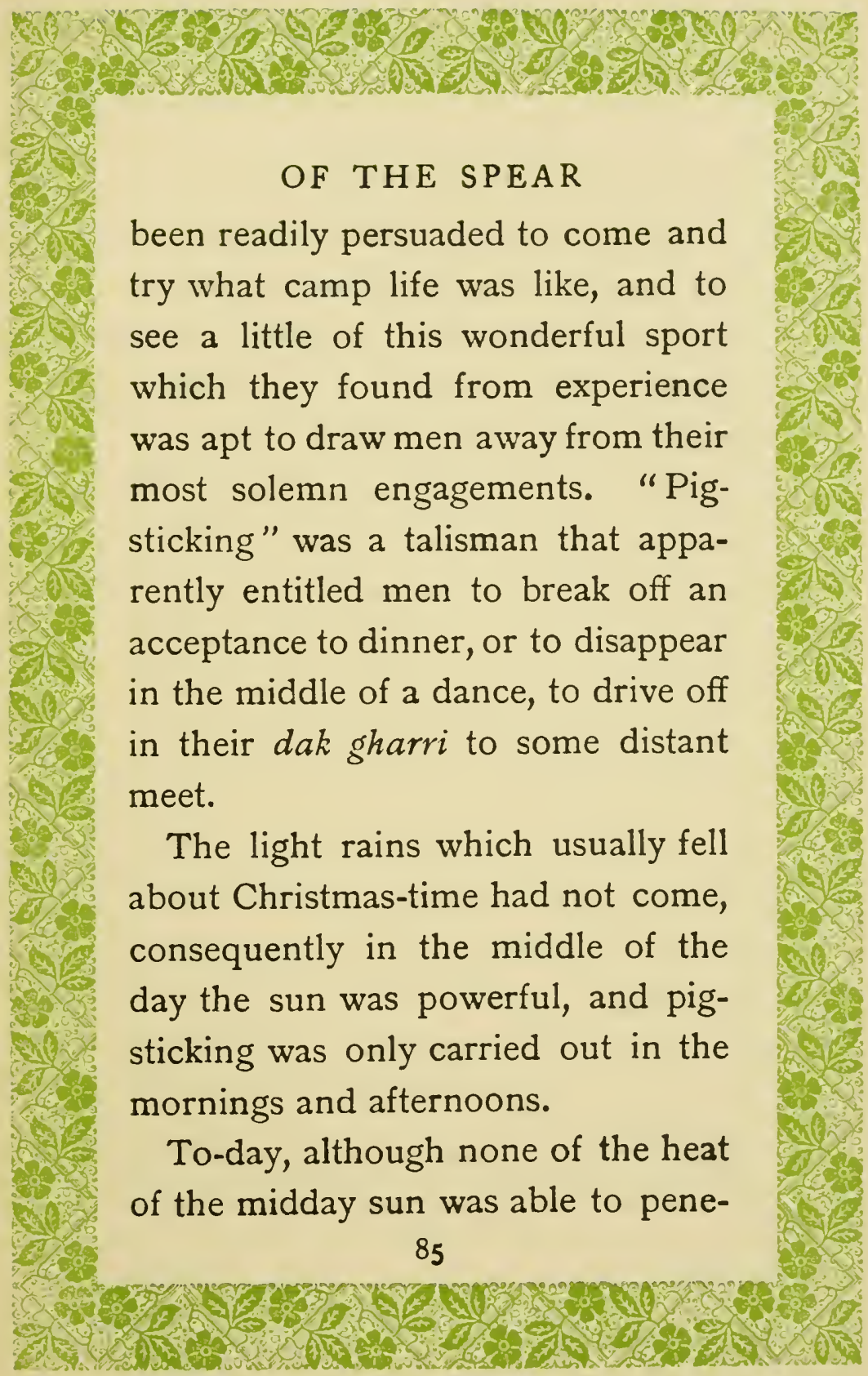




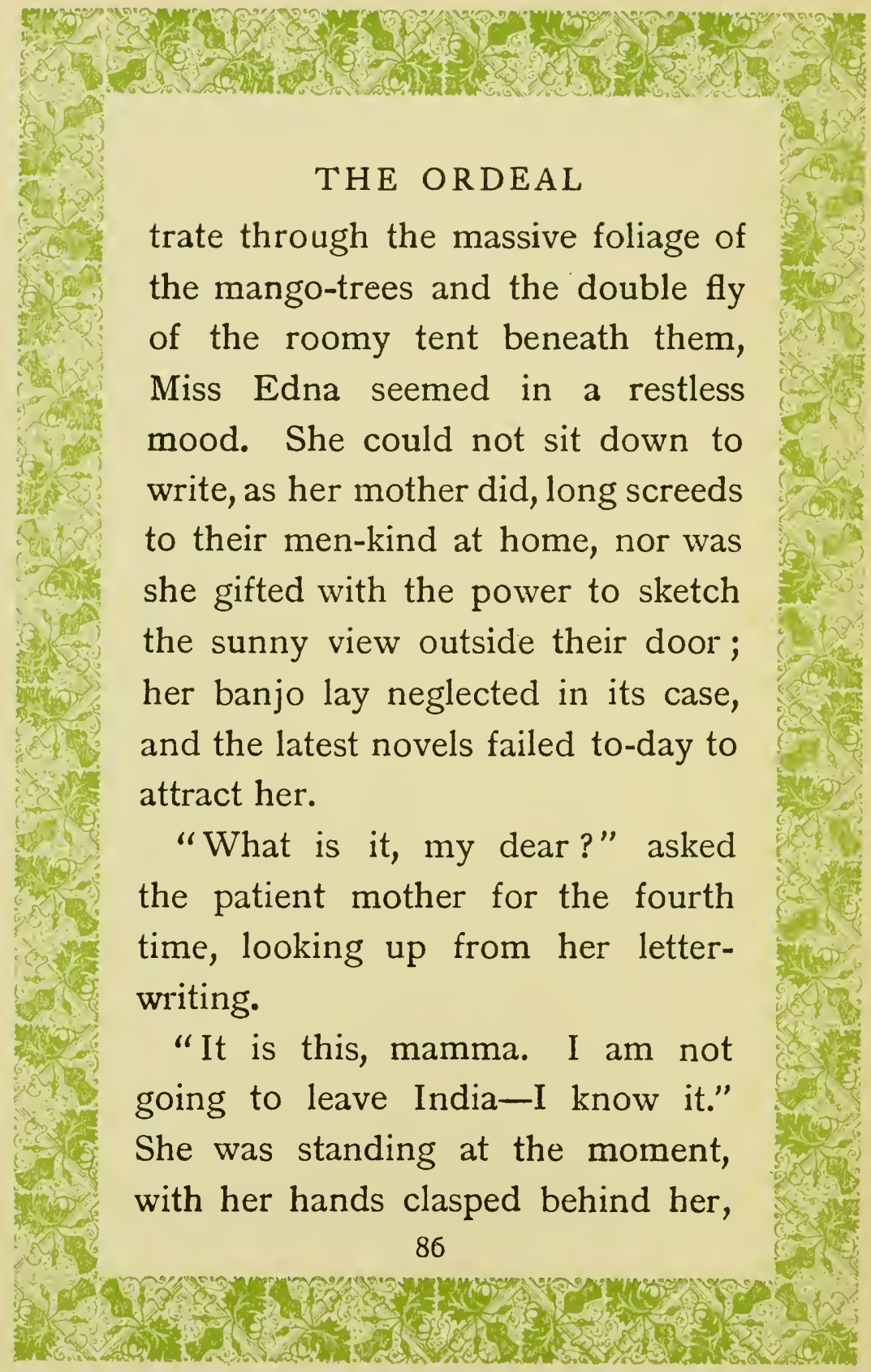




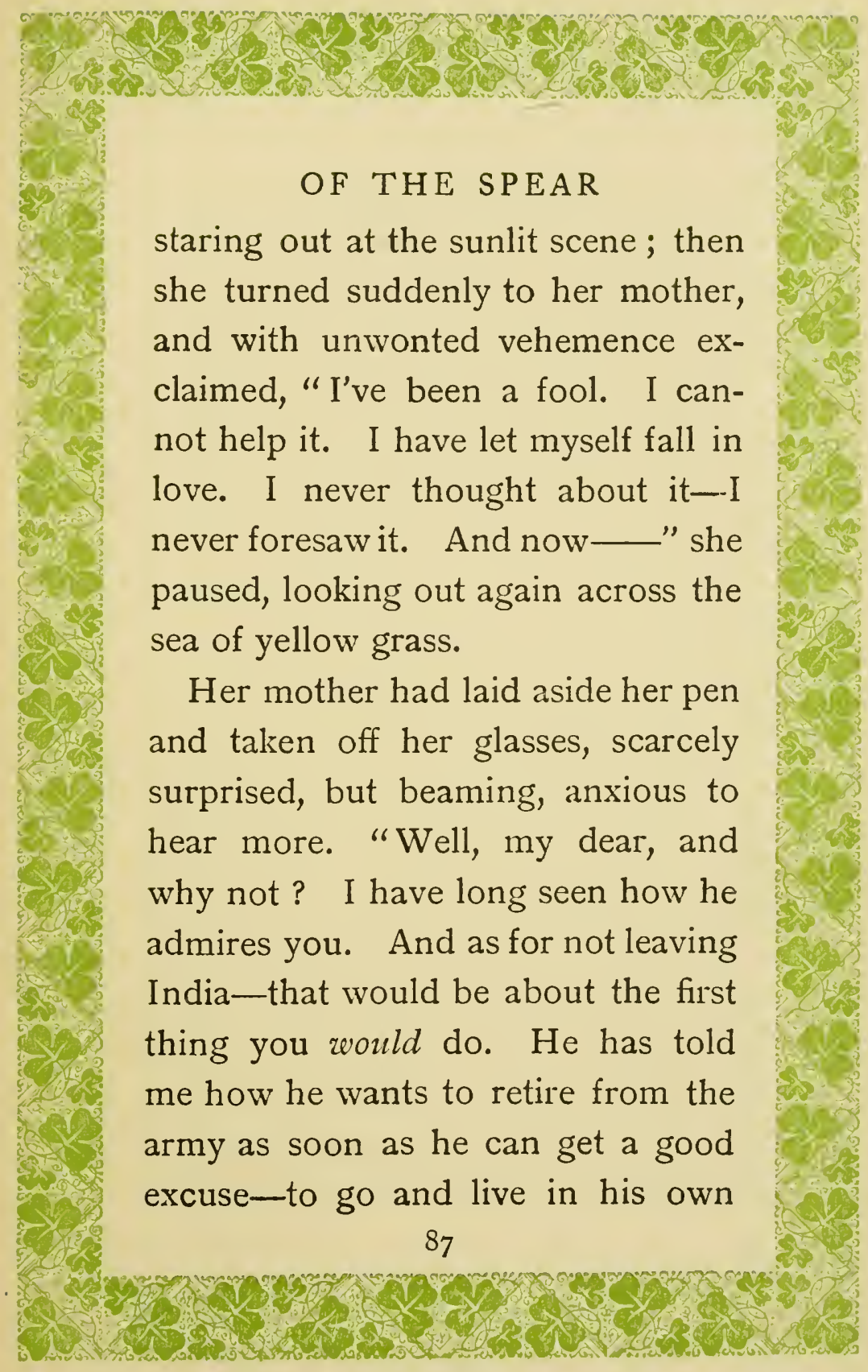




\section{THE ORDEAL}

family mansion, a superb place from what-_"

"Mamma," interrupts poor Edna, almost tearfully, "it is not "the Devil' I am in love with-I wish it were! It is the "Deep C.!'"

To say that she was taken aback would scarcely express the state of mind into which Mrs. Clay was thrown by this avowal. In vain she sought for words to express her protest; this match between her daughter and the Honourable Jack Austin, better known among his friends as "the Devil," she had fondly pictured to herself, and secretly and very cautiously had furthered to the best of her ability. For what other reason had she, at her time of life, left the comforts of a well-ordered house in 


\section{OF THE SPEAR}

Meerut for the unknown ills of camp life, but that Jack Austin would be of the party of pig-stickers in whose company she and Edna were to be thrown? Her dream, which had seemed about to culminate in reality, had been shattered at one blow, and she could scarcely for the moment realise the fact.

"And the 'Deep C.' too-of all people!" This was Major Calvert of the 6th, a dark, handsome, but taciturn man. "Whatever could Edna see in him ?" were points that suggested themselves to her mind.

"But, my dear child," she urged aloud, considerately putting in the second place that which she considered very much in the first, "Major Calvert is so-so staid; and 


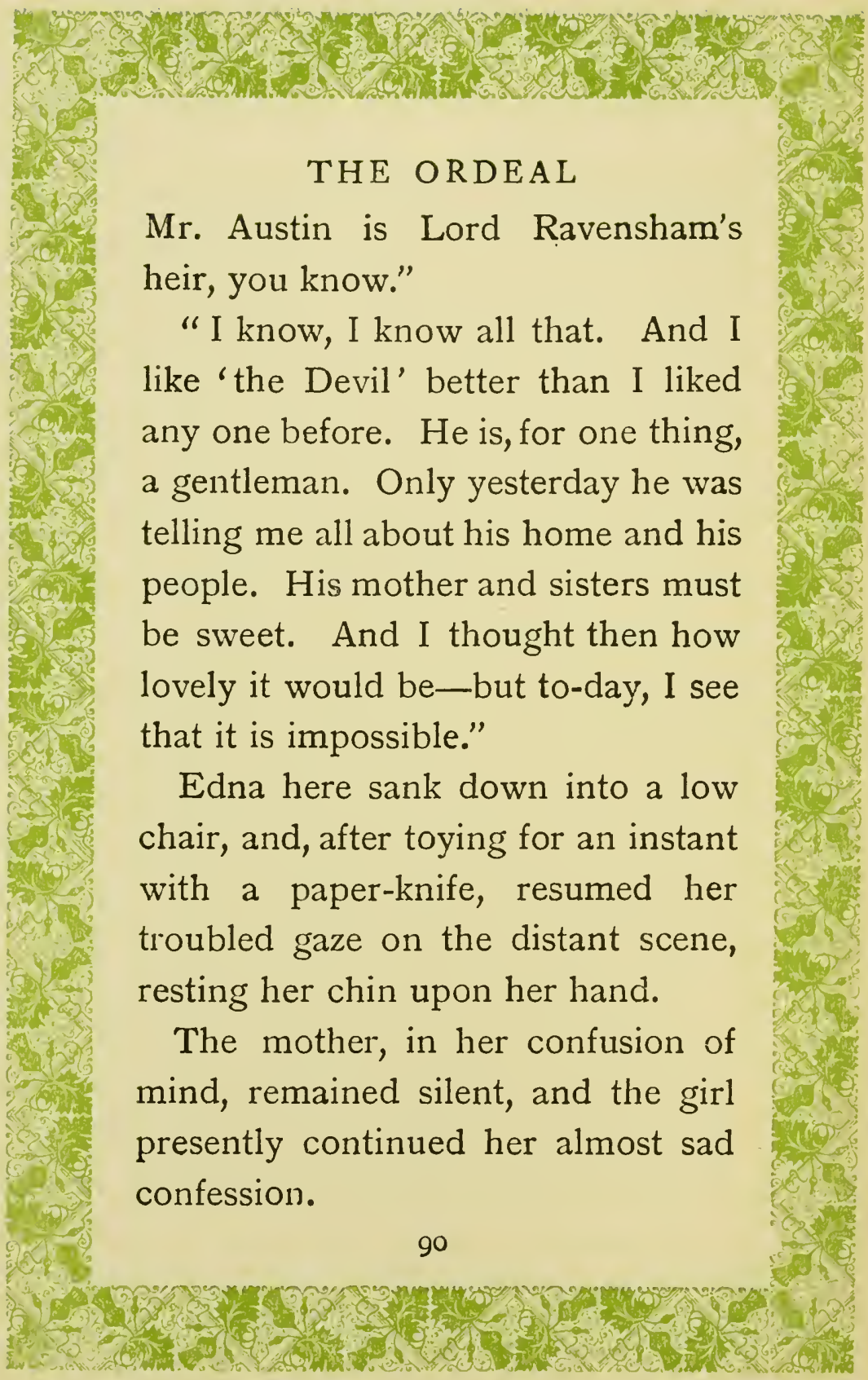




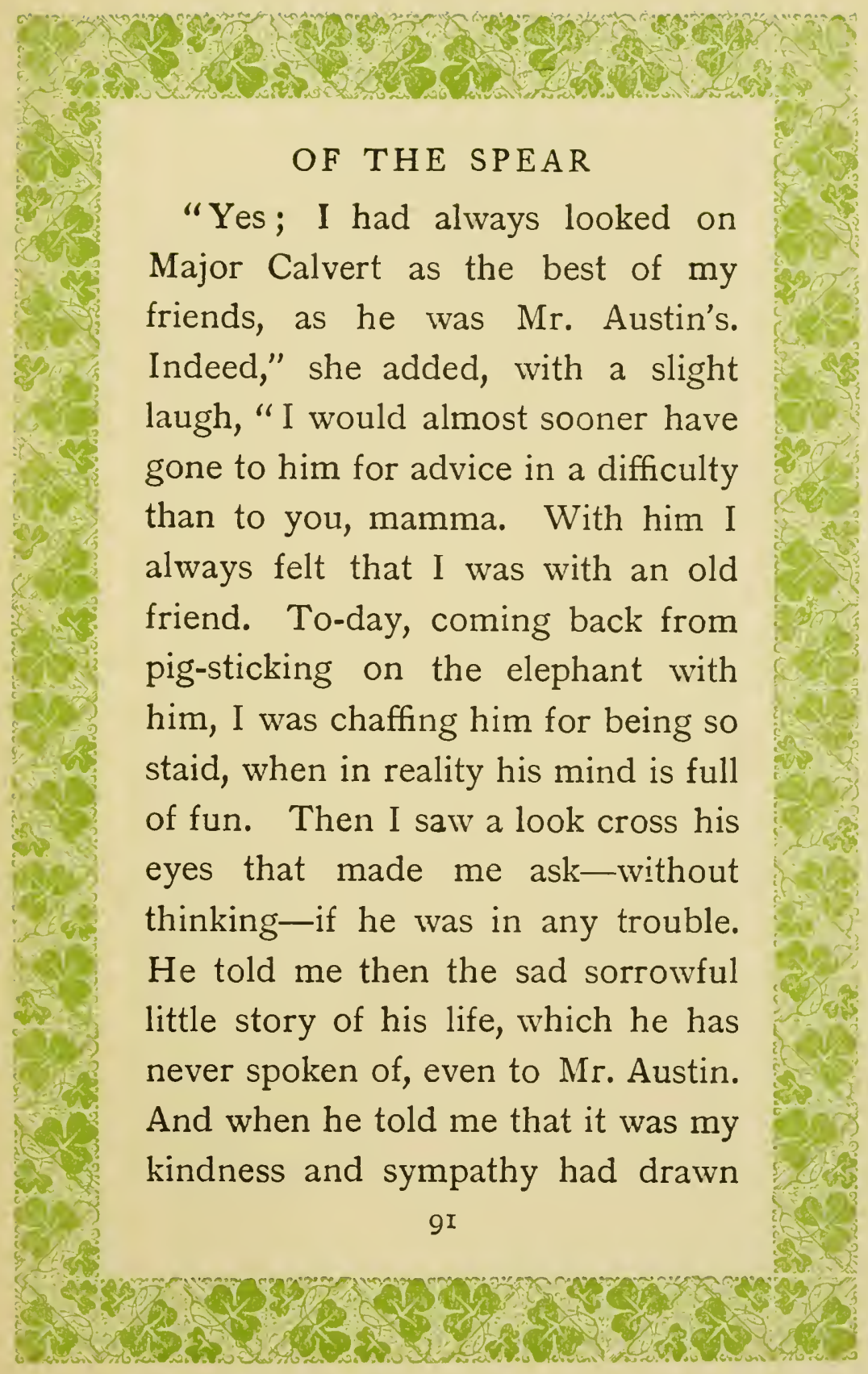




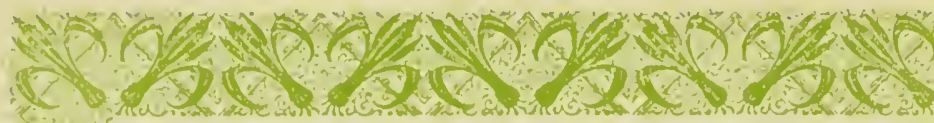 \\ THE ORDEAL}

him out, I thought what a prize he would be to any one as her helpmeet for life. Now I know that I love him as I never cared for any man before. And yet "-with a fluttering sigh of a laugh-"I suppose he would not look at me!"

In the meantime, while this conversation was going on between Mrs. Clay and her daughter, in the neighbouring camp Jack Austin and Cálvert were, by way of smoking together, in the latter's tent. I have never heard who first called them "the Devil" and the "Deep Sea." Though unlike each other in very many ways, they were an unusually good pair of friends. If you fell out with one-which was not an easy thing 


\section{THE ORDEAL}

like to the like is the proper apposition; but, as a matter of fact, this does not work out in practice, where like with the unlike very often hit it off completely and satisfactorily. Such had, in fact, happened in this case.

In their tent this morning, after the events of the morning's pigsticking had been discussed, there had been very little conversation between them; both had sat silently smoking for some time, which, after all, is the way of good friends. Suddenly the Devil broke the silence by exclaiming, "Look here, Bloggs"Bloggs was the name by which he usually addressed Major Calvert when not on parade-" I am tired of soldiering. I've hung on a bit hoping 


\section{OF THE SPEAR}

to see a little service, but British cavalry seem to be too carefully bottled up nowadays for one to have a chance of it. You have been lucky, and so, perhaps, you can't enter into my feelings. But that's how it is, and I'm going to send in my papers!"

"My dear chap, I quite agree with you about our fine old crusted cavalry, but a day may yet come! And besides, I don't see exactly why this sudden resolution, now, with the pig-sticking and polo tournament just coming on. You haven't had to do orderly officer 'more than three days a week on an average,' as Mr. Glimmer would say-what has put your back up ?"

"Nothing has put my back up. 95 


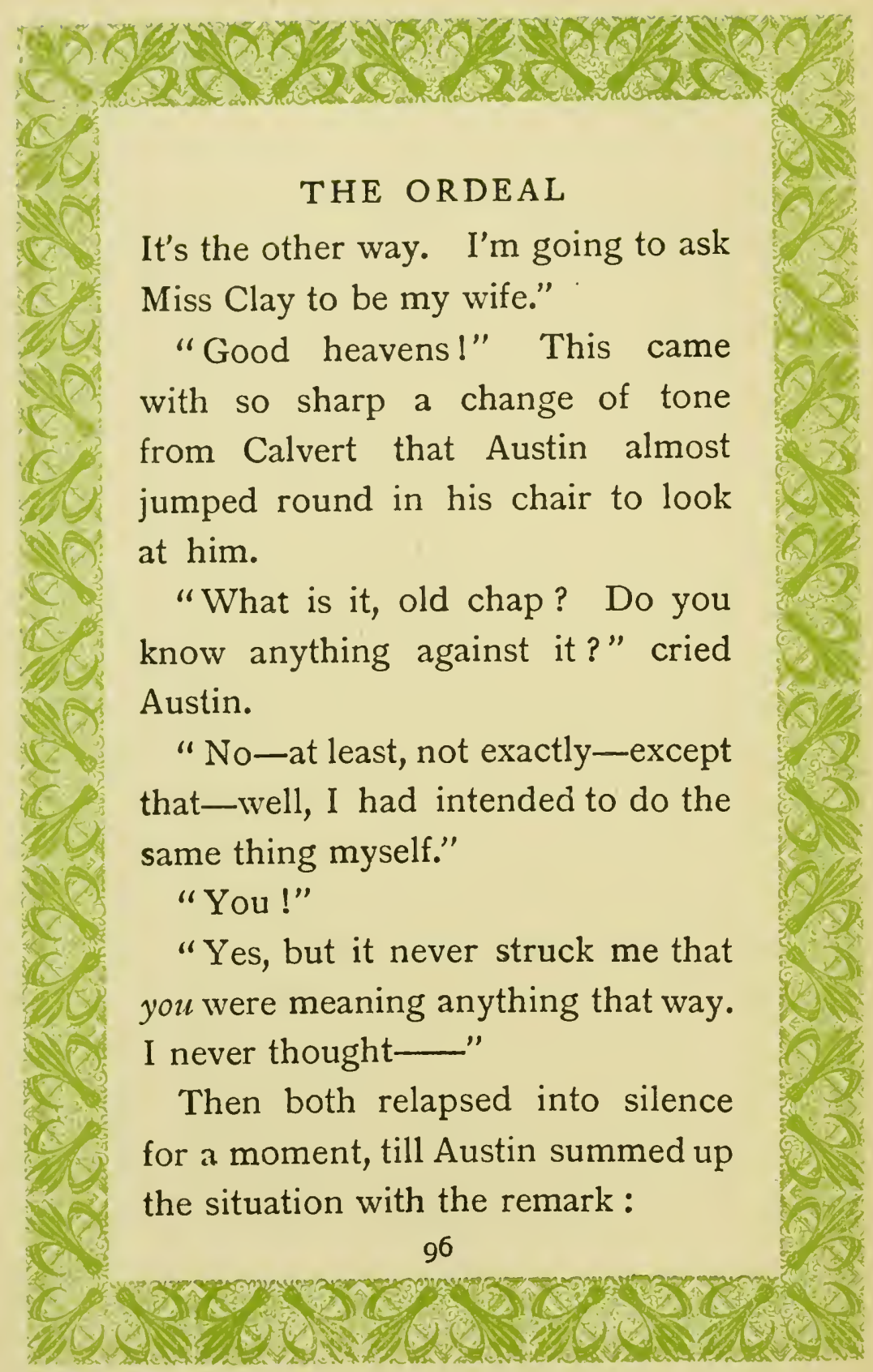




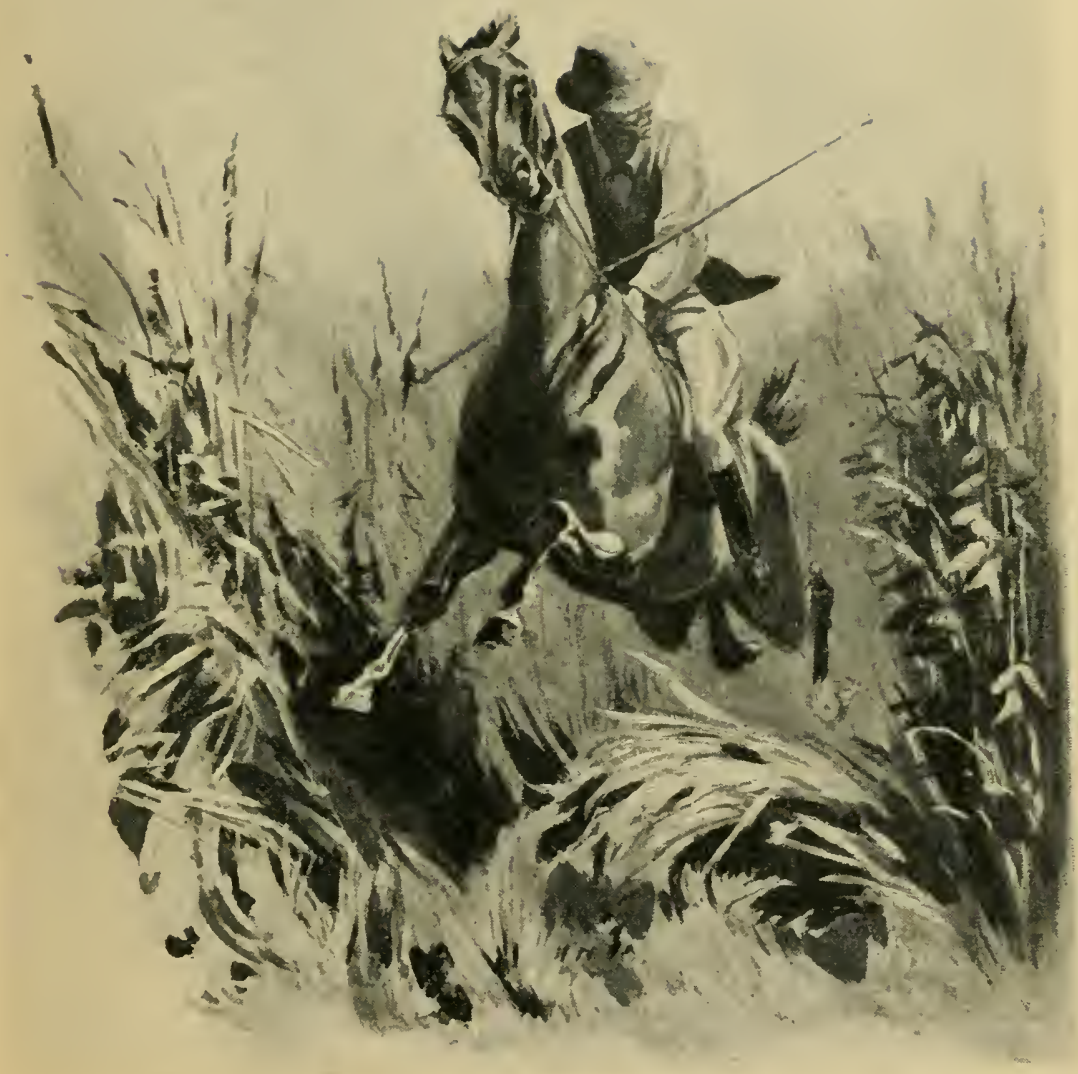

A VETERAN HAND AT THE GAME 



\section{OF THE SPEAR}

"Well, by gum, we are in a queer hat! What is to be done?"

There was then a silence for so long that Austin, coming back to the actual situation first, exclaimed, "Bloggs, are you asleep ?" Calvert, who was lying back in an armchair, no longer smoking, merely flung back the word with some scorn in his tone, "A-sleep !"

The Devil, finding that he had an audience, proceeded to give out his views: "Well, I've been thinking it over, and I don't see a way out of the difficulty. You haven't asked her, you say; have you broken ground at all ?"

"Yes, I have in a way broken the ice."

"Well, then, we're no better off 


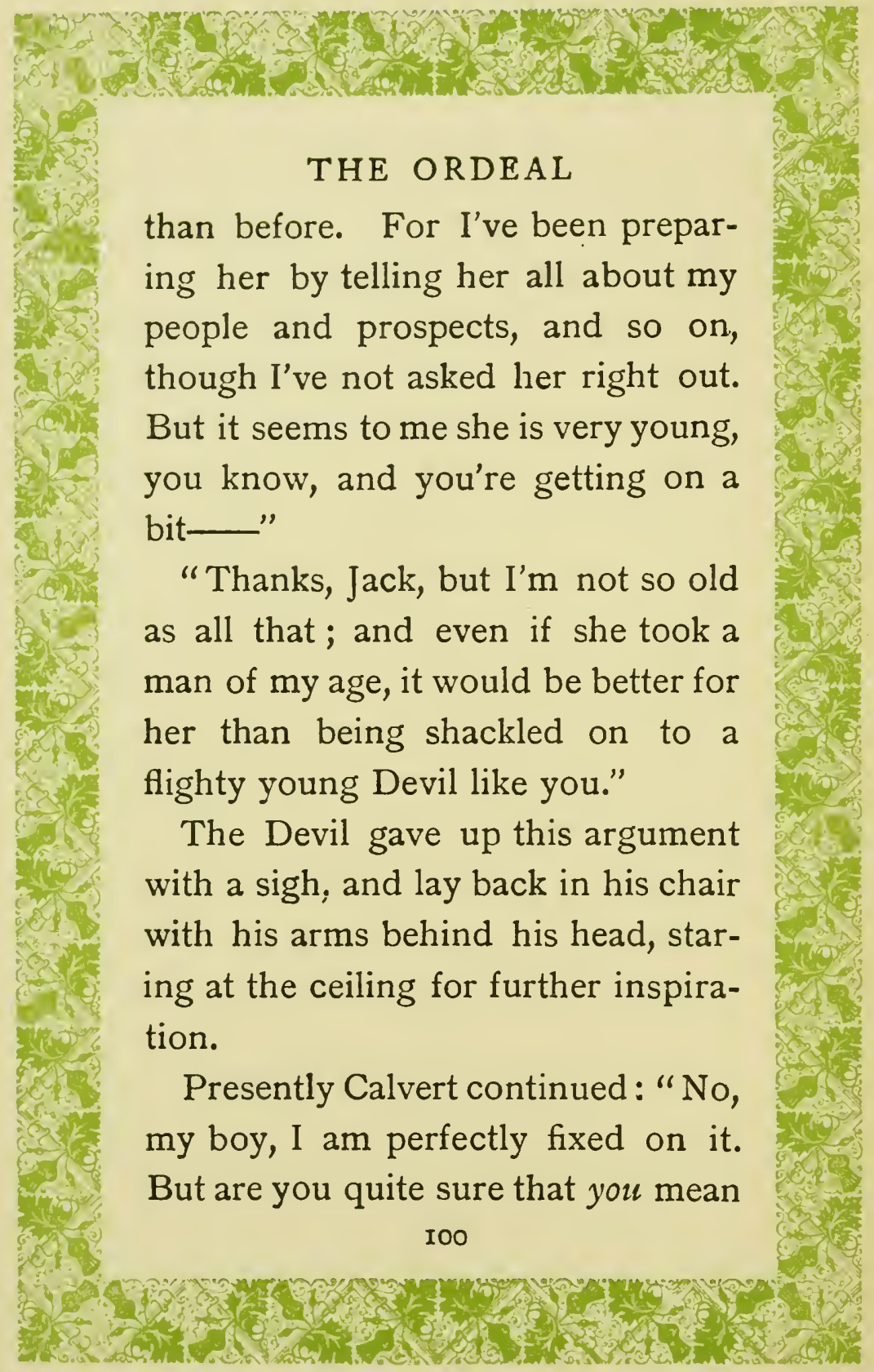




\section{OF THE SPEAR}

business? May it not be with you one of those fascinations which you'll allow do come to you now and then?"

"No; in those affairs I never speak of my people and prospects," retorted the Devil with proper pride.

"Quite right. I even found a difficulty in speaking of my prospects, so gave her more of my past, from which she could herself evolve my character."

"Your past! Oh, by George! then I give in. A man with a past is a hopeless chap to contend against. A girl will jump at him like a trout at a fly; she don't care what his future is likely to be provided he has got a past. Well, it seems to me that we are as we were." 


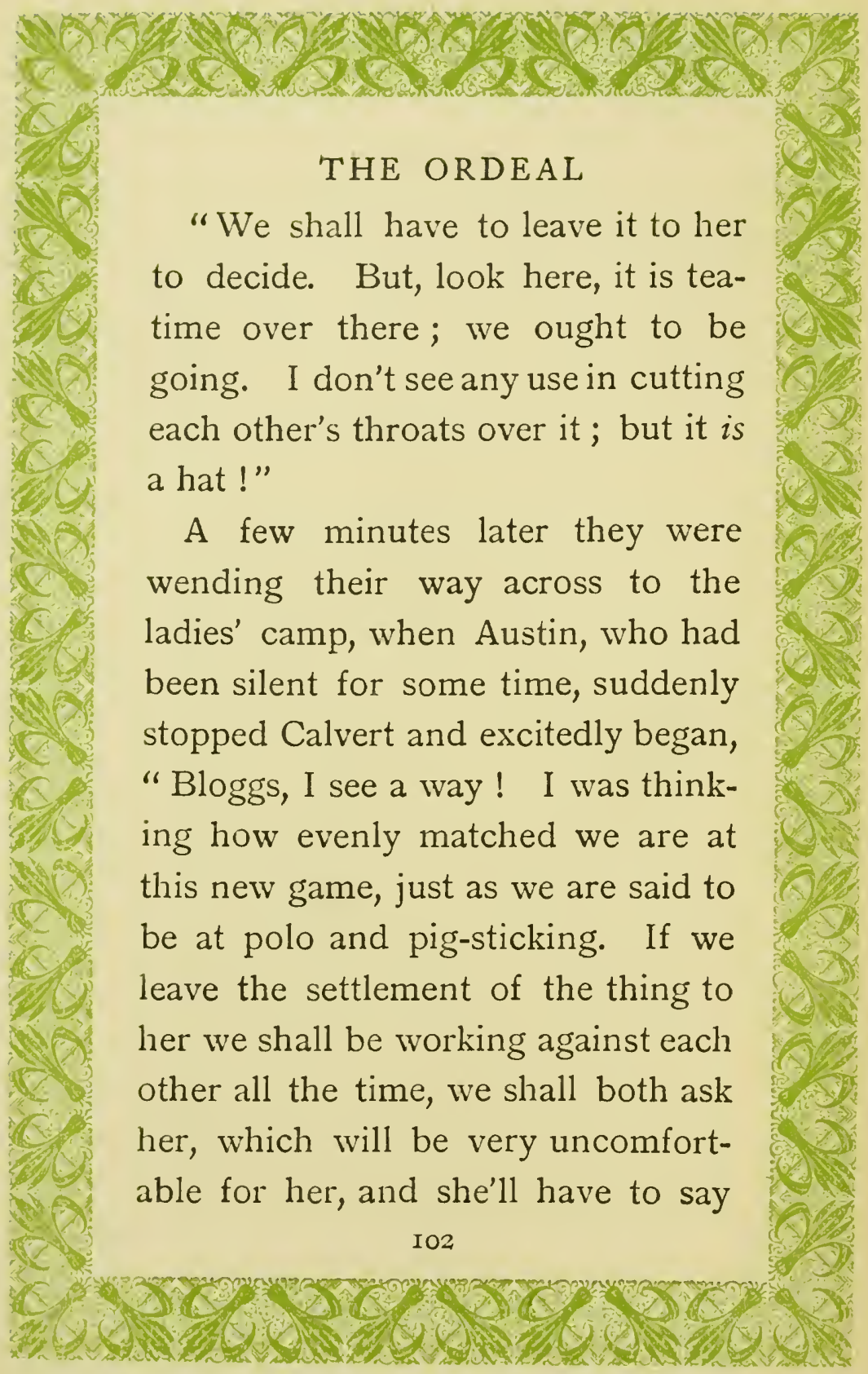




\section{OF THE SPEAR}

' No' to one of us, which will be $\mathrm{d}$-d uncomfortable for him. One is almost inclined to draw lots about it, but that is so jolly unsatisfactory for the loser. What do you say to having a match after a pig, you and $I$, and whoever wins to have first right to ask her? I'm lighter than you, but then they say that a man over thirty is better at pig-sticking and polo than a young 'un, so that about makes us level. Your little Arab is

Calvert, who had smiled curiously at this new idea of the boy's, while his eyes sparkled at the sporting smack of it, now suddenly grasped Jack's hand and laughingly said, "Right you are, old boy; let's have it that way. The ordeal of the spear 


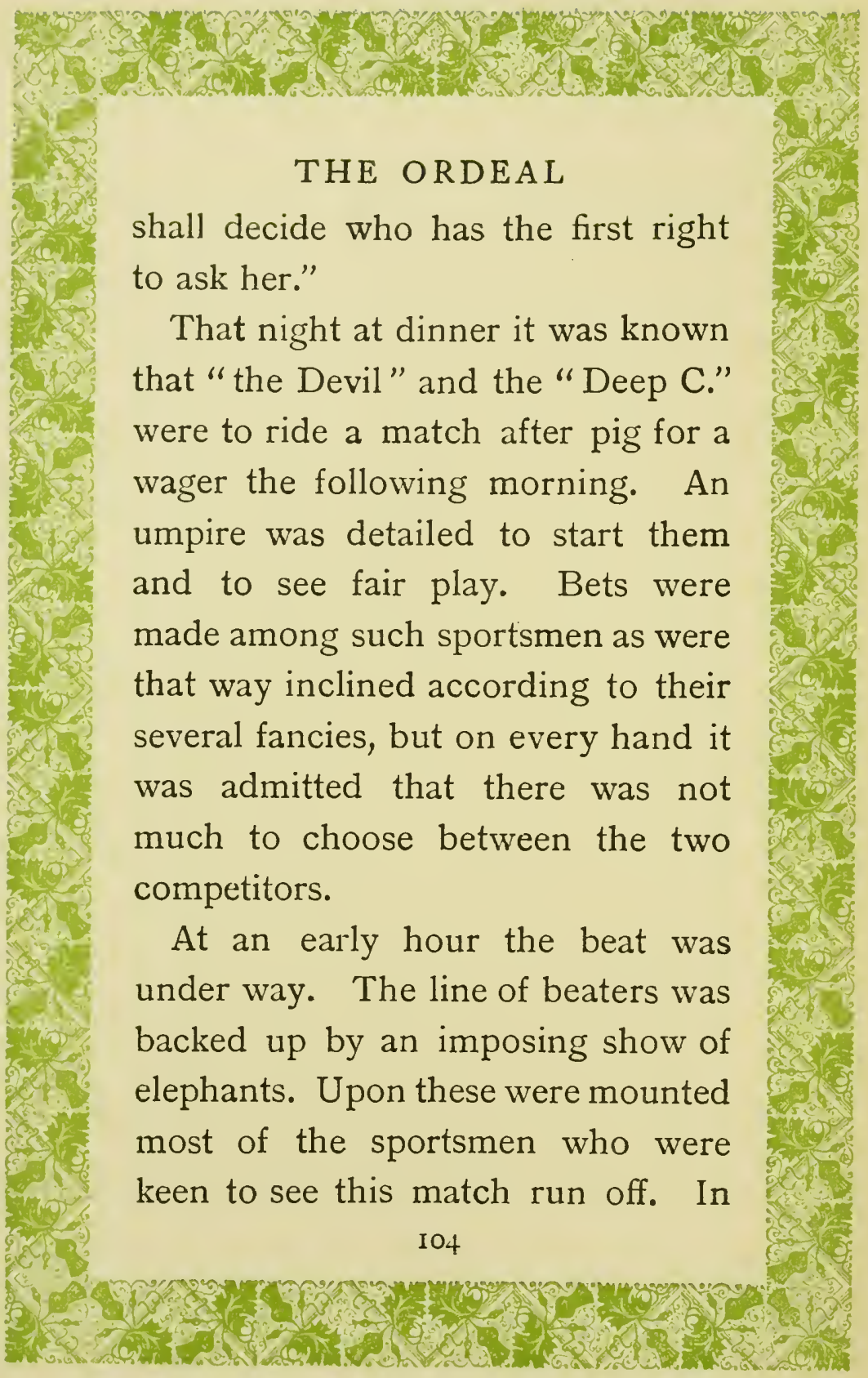




\section{OF THE SPEAR}

front of the centre of the line rode Jack Austin on his keen little Waler mare, "Lovelei," and Major Calvert on his Arab "Kismet," and in close attendance rode "old" Baynton, the collector of the district, a veteran hand at the game, and still hard to beat as a straight-going, deadly man after a pig.

The ladies were not yet out, but an elephant had been left at their camp to bring them on when ready.

The line slowly and quietly beat its way through the long grass of the Kadir plain, working gradually away from the tree jungle and the nullahs that fringe the edge of it. A few small pig were soon afoot, but nothing that Baynton considered rideable. 


\section{THE ORDEAL}

Suddenly there arises a loud yelling from the beaters on the extreme flank of the line. Old Lutchman, the shikari, knowing of the match, is for once in his life excited. Standing on his elephant he holloas the party on, "Wuh jata hai! burra dantwallah!"

Baynton, clapping spurs to his horse, leads the way in the direction indicated, closely followed by the two riders. In a minute or so he is able to point out to them the form of a fine young boar louping away through the yellow grass, back in the direction of the nullahs.

"Do you all see him?" he cries: "then, ride!" And away go Jack and Calvert with an even start.

The pig has got a good offing, and I06 


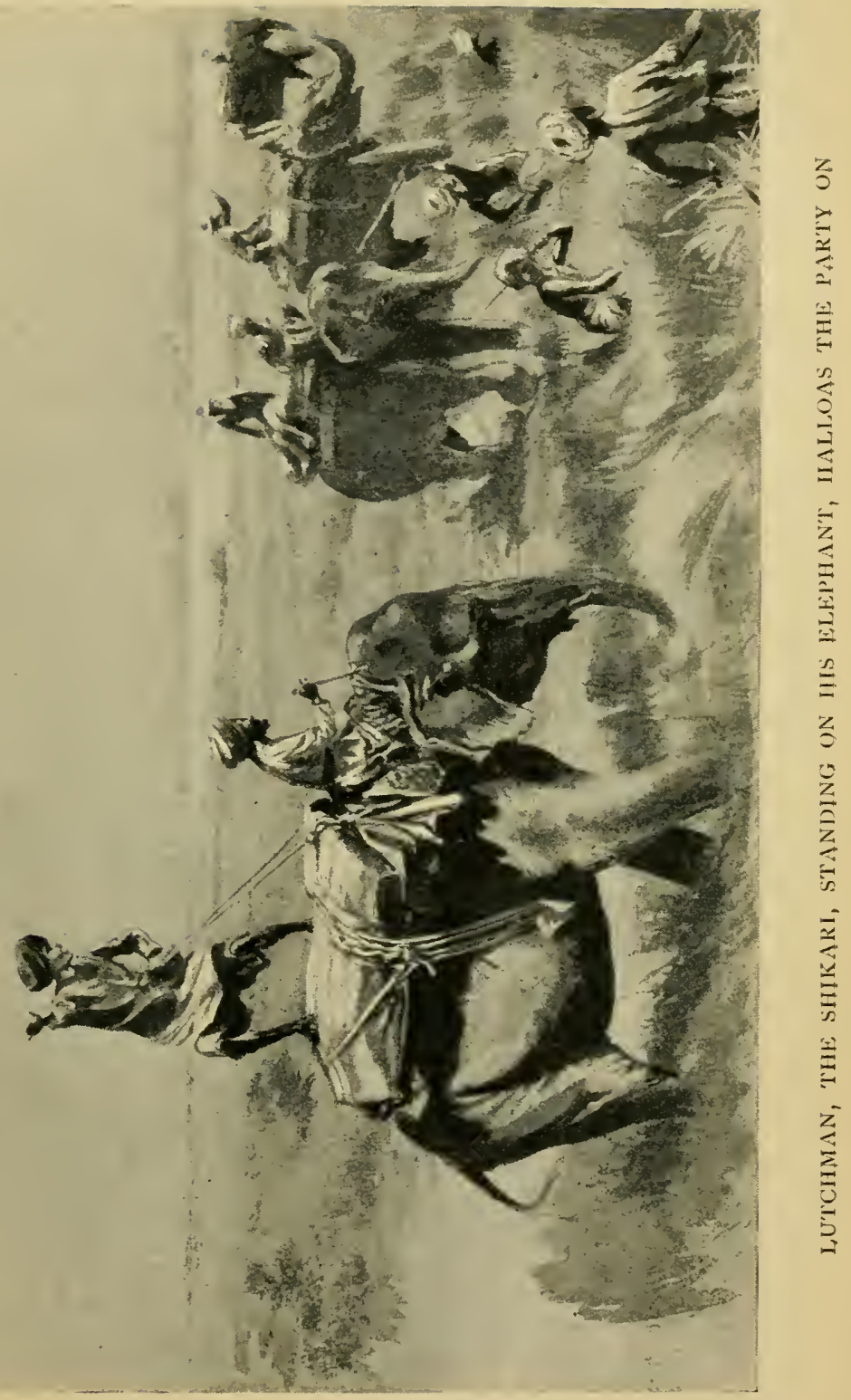





\section{OF THE SPEAR}

is going at a very fair pace, so that they have a long, straight gallop before them to begin with. What are their thoughts at this moment it is hard to say, but possibly the sense of the importance of the occasion is alreadydrowned in the more palpable delight of a racing gallop with the game in view.

That they are both putting on an extra turn of speed is evident from the way they are leaving old Baynton behind, though he is by no means undermounted. Gradually, however, slowly and surely the weight begins to tell, and Jack shows a little ahead of his rival. Elated he presses on, steadily improving his lead.

They are now nearing the boar, and he, laying back his ears and IOg 


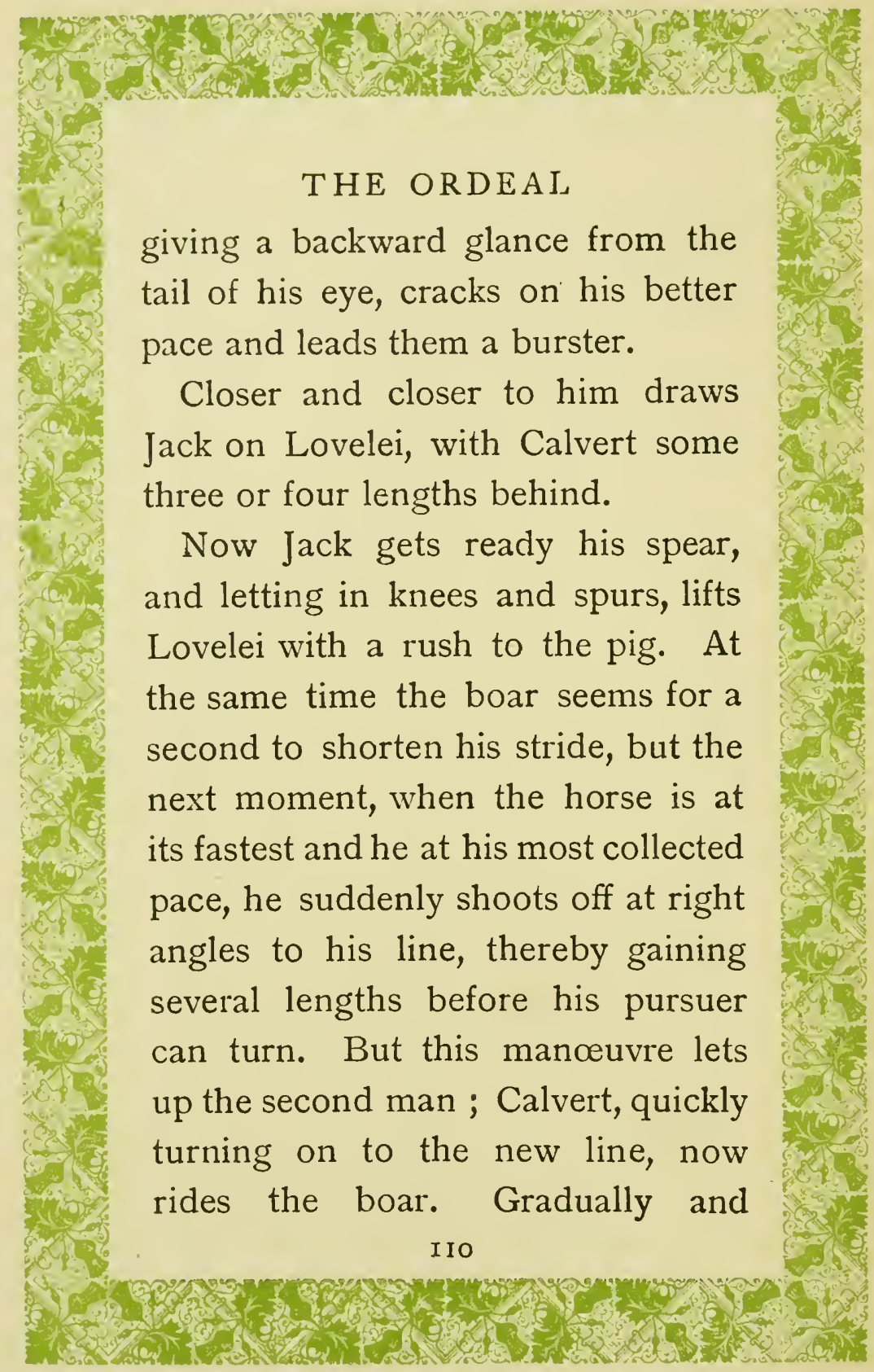




\section{OF THE SPEAR}

steadily he comes up to him; his spear is ready; the boar pricks his ears and gallops high as he shortens his stride. Calvert knows that a "jink" is coming, collects his horse, and is ready for it when the pig suddenly turns across his front. Round he comes on the instant in the same direction, and Jack, who is close behind, similarly turns to the left; but before they have gone two strides the pig twists abruptly round again and leaves them both several lengths to the bad as once more he heads for the nullahs.

Again it is a neck-and-neck race between the two riders, Calvert having a little the best of the start. Indeed, it is a ding-dong race between all three, for the boar has his head 


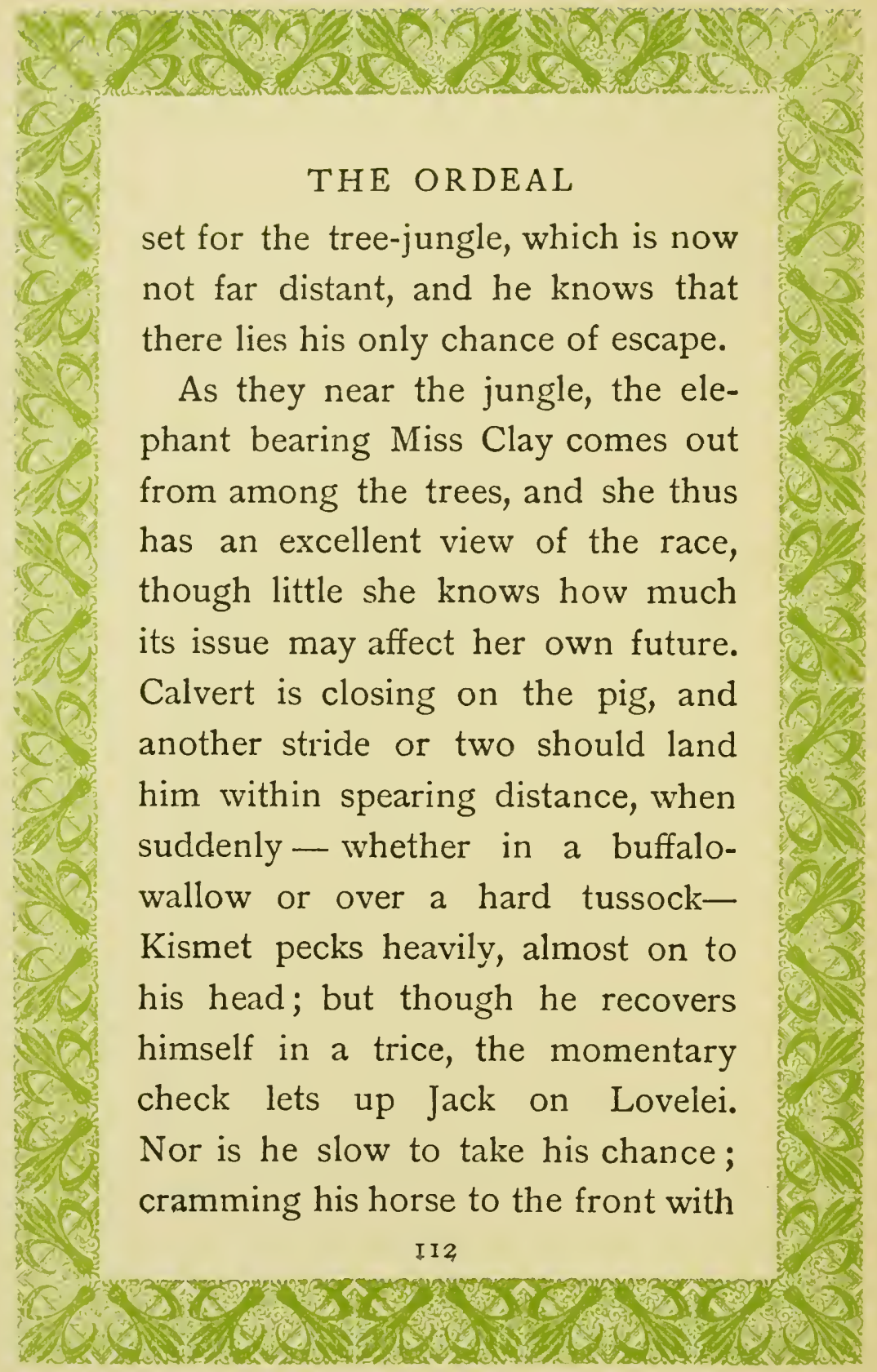




\section{OF THE SPEAR}

one extra spurt, he comes on the pig with a rush, and leaning low he drives his spear-point into the burly flank. It is not a good spear, but it counts as "first."

At this moment for the first time he sees that Miss Clay, now close above them, is spectator of the game. The magnitude of what he had, in winning first spear, won, now dawns upon him, and as he tosses high his spear, his lungs give vent to an ear-piercing "who-hoop" of exultation.

Calvert, probably too engrossed in the matter in hand to realise his loss, dashes in, and with a crashing stroke rolls the boar head over heels. But the trees are near; the pig is up again and quickly in among them. 


\section{THE ORDEAL}

Here he gains a little on the men until an open glade is reached, where, finding that they press him still, he turns, and beginning with a shambling trot, breaks into a gallop, and with ears pricked and fire in his eye comes in at the charge. It is met with all the shock of a firmly held spear and a fast-moving horse, and he reels back repulsed but not daunted; a second time he hurls himself against a foe, and a second time the deadly spear crashes into him. He can do no more. Disabled, he sinks on his haunches, his jaws, champing in anger, drop foam and blood. As his enemies once more approach he turns to face them, his little eyes gleaming red with rage, but he cannot rise, and a 


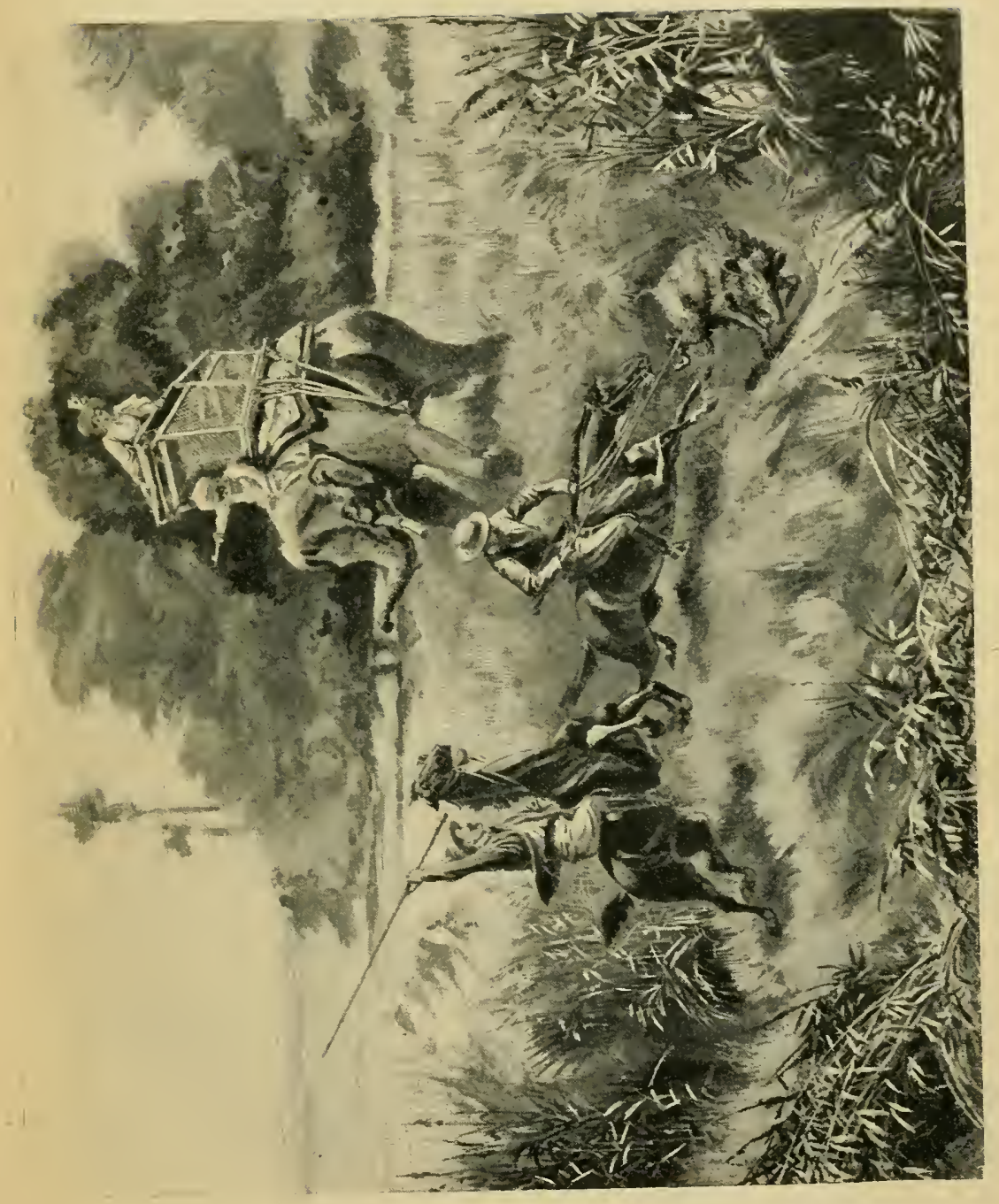

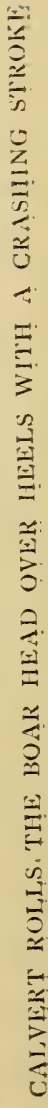





\section{OF THE SPEAR}

merciful spear through the heart drops the gallant beast dead.

While Jack is loosing Lovelei's girths, he feels a kindly pat on the shoulder as Calvert says to him, "Well done, old boy; go in and try your luck. It was a good run, wasn't it ?"

*

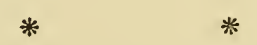

As they led their tired horses slowly back towards the open a native came hurriedly towards them from some neighbouring huts. With a scared face he told his story.

In a few minutes they were standing beside the body as it lay upon a common native charpoy. She looked almost as if she were resting after a bout of tennis. Her white frock and gay silk blouse were fresh 


\section{ORDEAL OF THE SPEAR}

and scarcely dishevelled; but there was an awkward uprightness about the small brown shoes; her form seemed flattened down into the cot, and the unnatural sternness about the waxen face, with its half-closed eyes and parted lips, showed that Edna Clay was dead.

Her elephant, frightened at the final rush and turmoil of the race, had turned and fled among the trees, to the instant destruction of the howdah and its occupant. 


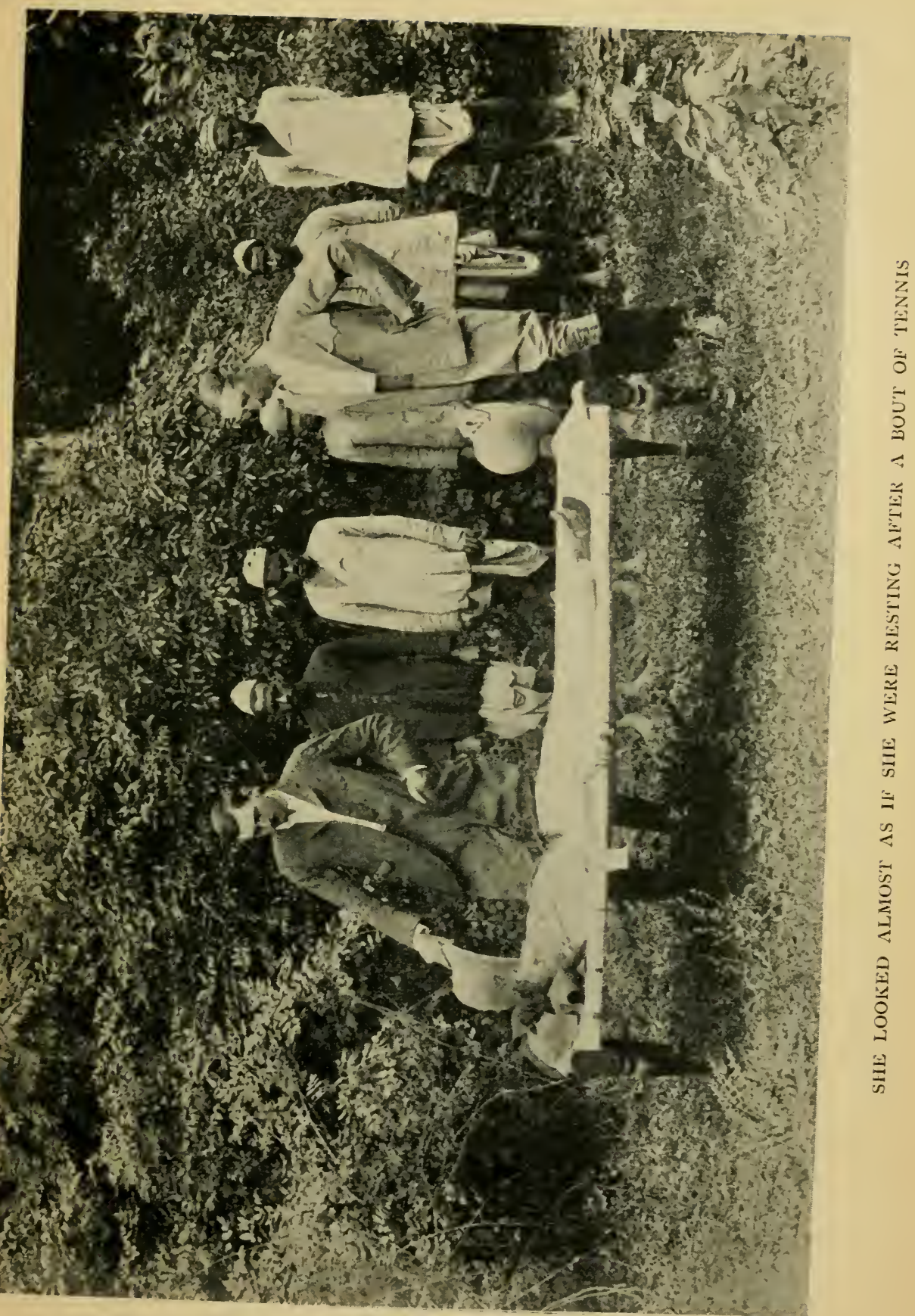





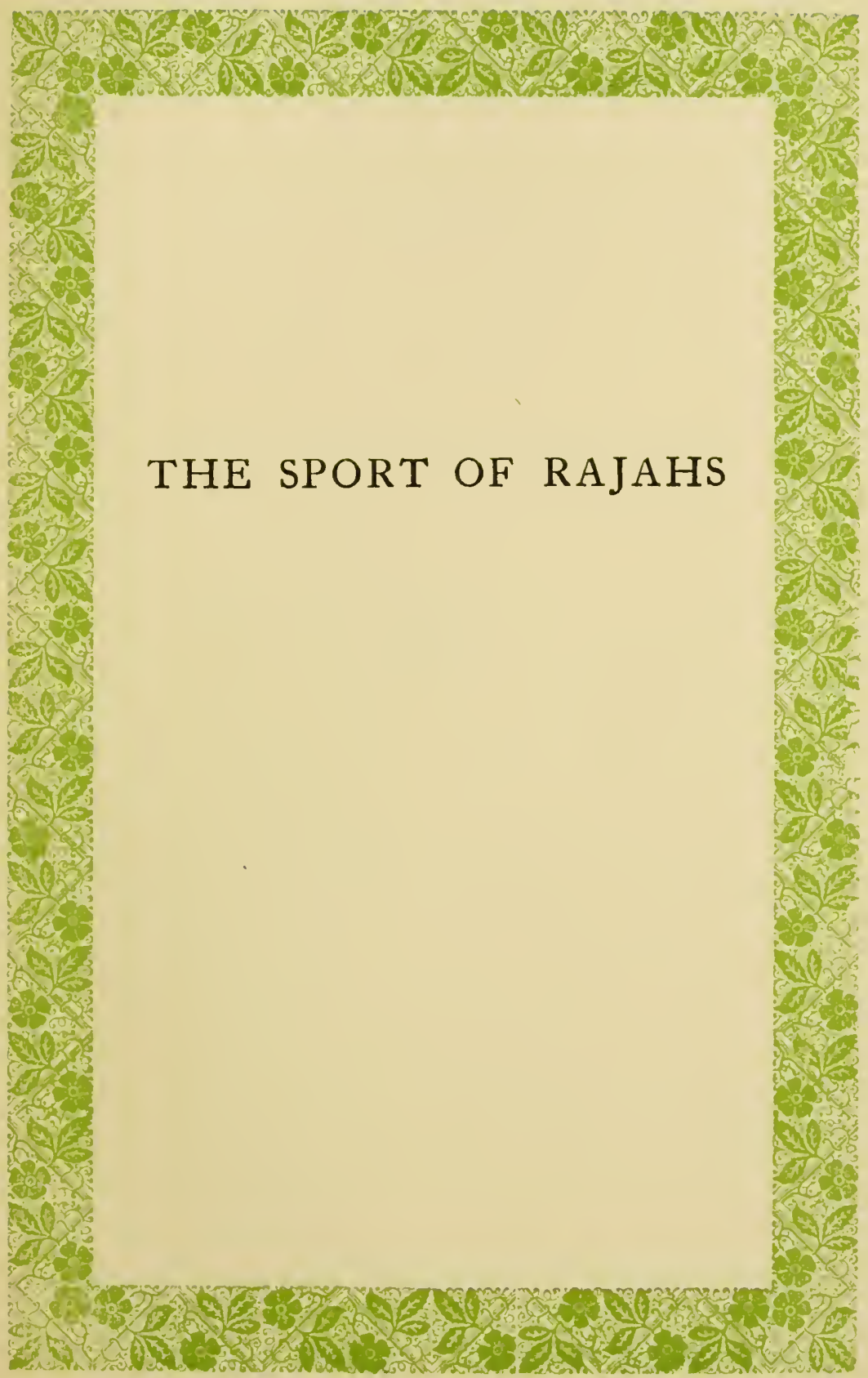




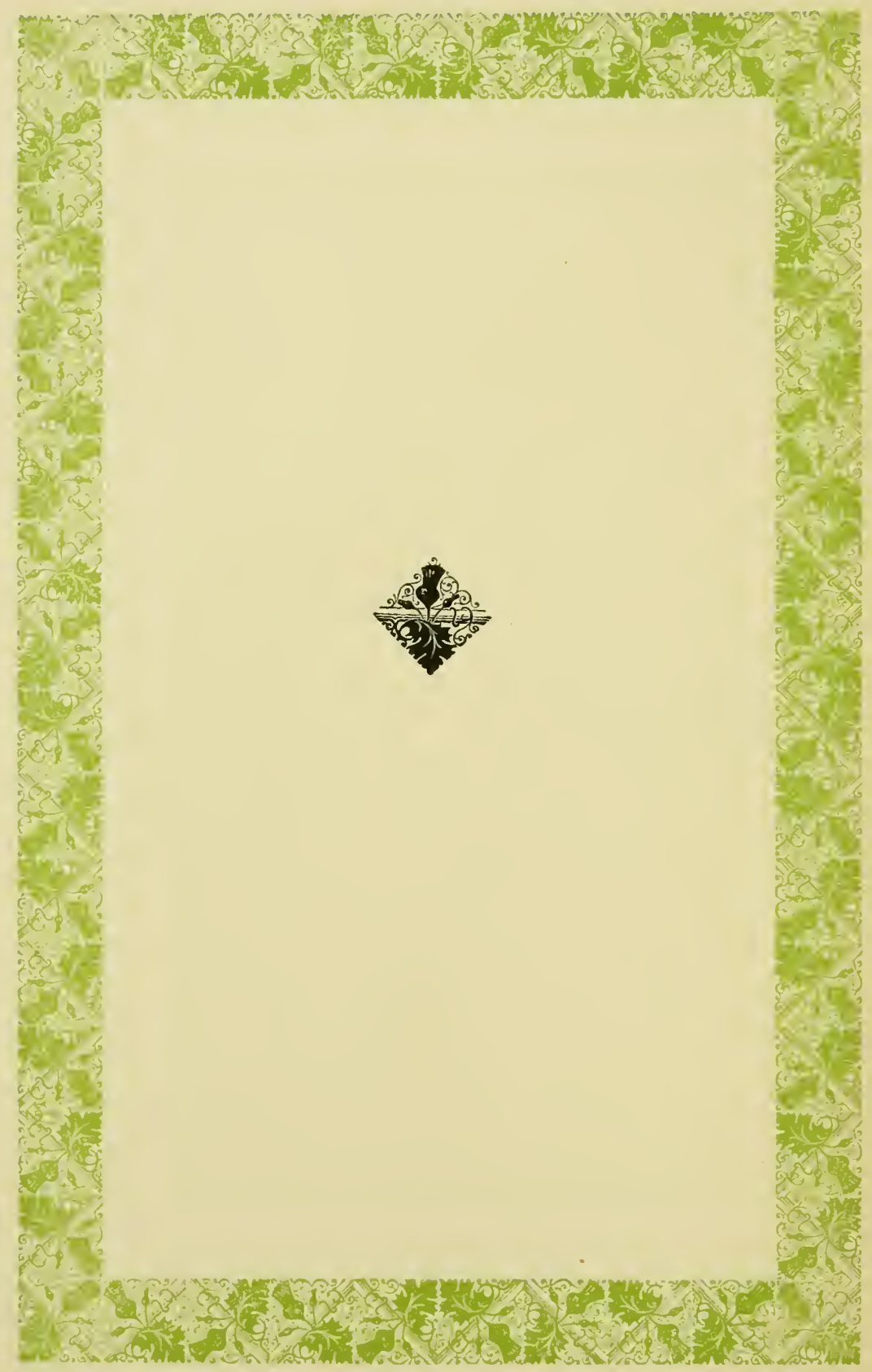




\section{THE SPORT OF RAJAHS}

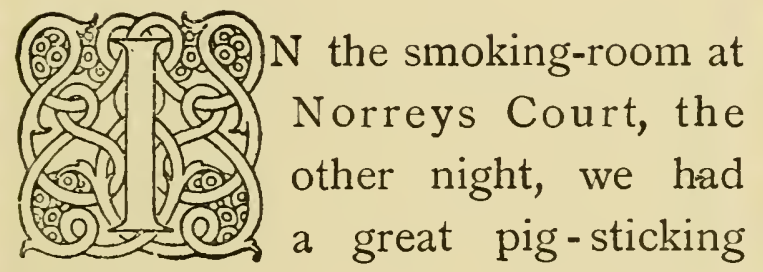

"buck."

As is usual where a few Britons are gathered together, several of the party had visited India and knew something of the subject, but it struck me forcibly how ignorant, as a rule, are home-keeping sportsmen of this and kindred Eastern sports. 


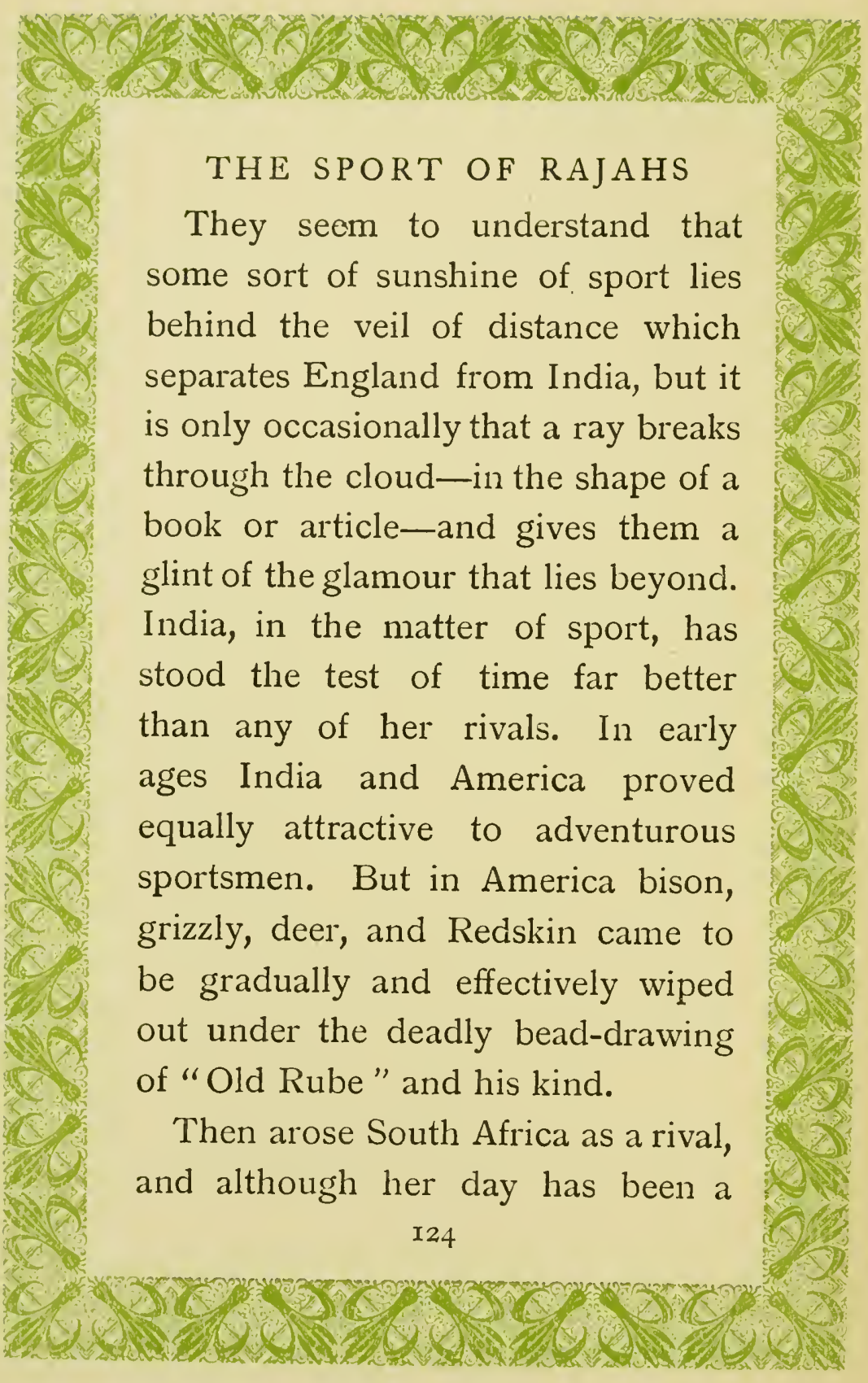




\section{THE SPORT OF RAJAHS}

happy one, its sun is setting; ere the next century has well begun, advancing civilisation and improved breechloaders will have cleared off the elephant, rhino, lion, and buck that have made Africa so happy a hunting-ground these past sixty years.

Yet India still maintains her head of game, and bids fair to do so for many years to come. From the North, with its Oves ammon and poli, bears and ibex, to the South, with its tiger, buffalo, sambur, and boar, the sportsman finds game worthy of his steel, in addition to abundance of the lesser kind of buck and bird, and fish and fowl. But, as an old doggerel has it,

The sport that beats them o'er and o'er Is that wherein we hunt the boar. 


\section{THE SPORT OF RAJAHS}

Pig-sticking is the acknowledged king of Eastern sports, and there are many reasons why it should and must be so.

For one thing, it demands the assistance of the horse, and this in itself commends it more particularly to the Anglo-Saxon race. Then it is one of the few sports in which the hunter is almost always associated with others of his kind. In most big-game expeditions the shooter is attended only by a few trackers or beaters - more guns would spoil sport; and, although there may be, and is, a certain charm for a time in such-solitary life, yet eventually the sportsman cannot but long for companionship of his fellows in his evening camp. Nor is it good for a I26 


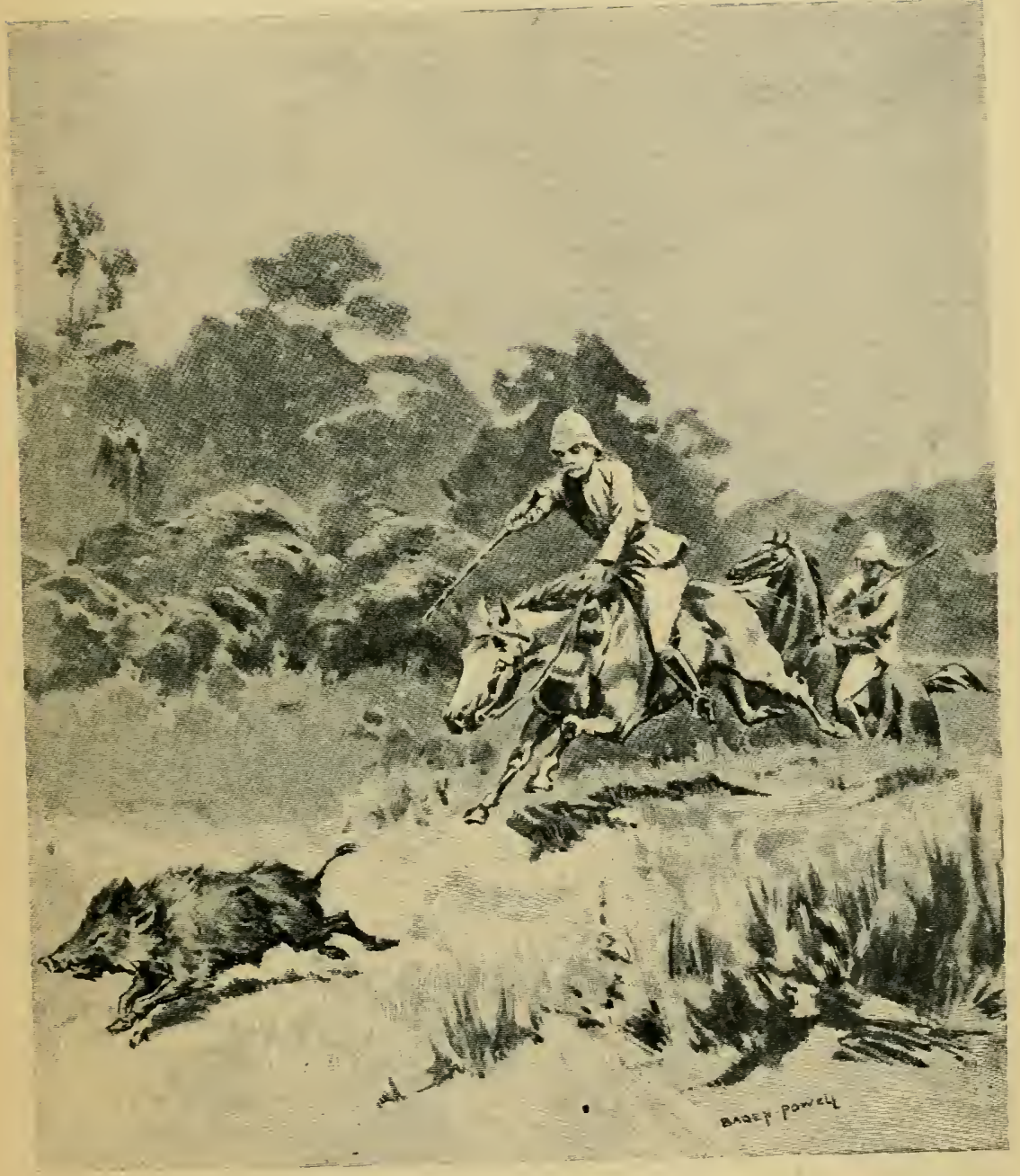

THE KING OF EASTERN SPORTS 



\section{THE SPORT OF RAJAHS}

man to become accustomed to a solitary life ; Englishmen are already misanthropical and reserved enough in all conscience, without such further training. In pig-sticking, on the other hand, the hunters live, and move, and hunt in parties; and yet individual excellence is as necessary as ever to success, while it gains the additional spice born of friendly rivalry with one's fellows.

Again, the risks and chances, which after all form a great part of the charm of most wild sports, are in pig-sticking incomparably greater than those in ordinary tigershooting; that is to say, tiger-shooting from an elephant, for I do not look on that carried out on foot as 
THE SPORT OF RAJAHS

anything but foolhardiness, except under special circumstances.

Moreover, the quarry is not only fast and crafty, but he is also plucky, powerful, and cruel; he enters fully into the spirit of the chase, and he will generally give you a good fight as well as a good run for your money.

That pig-sticking has an affinity to the sport of all true British sportsmen-viz., fox-hunting-cannot be denied, but that there exists a neckand-neck resemblance between them is not so easy to see. Yet much midnight oil and gas, liquid and tobacco smoke, have been consumed in country-house billiard-rooms over the discussion and comparison of their respective merits. 
THE SPORT OF RAJAHS

As a matter of fact, pig-sticking may equally claim an affinity with polo and with racing. And to the glorious attractions of these it adds a taste of the best of all huntsnamely, the pursuit, with a good weapon in your hand, of an enemy whom you want to kill.

In pig-sticking every man rides to luunt, whereas in fox-hunting the majority (although for some occult reason they will seldom own to it) lunut to ride. The first part of a pigsticking run partakes rather of the nature of a point-to-point race, since each man is endeavouring to be first to come up with the pig, and so to gain the honours of the run; and, while keeping one eye on the object in view, he has to keep the other on 
THE SPORT OF RAJAHS

the doings of his rivals, so far as the elation of a glorious gallop will allow him.

When the "first spear" has been won, the dodging and turning and quick rallies required for fighting the boar have no little resemblance to the galloping mêlée of the polo-field, till, with your worser passions roused as the grizzled old tusker pits himself against you, you meet charge with charge, and, blind to all else but the strong and angered foe before you, with your good spear in your hand, you rush for blood with all the ecstasy of a fight to the death. And then :

All's blood, and dust, and grunted curses.

Well-this is a different thing from the pleasurable enjoyment to be 
THE SPORT OF RAJAHS

derived from a gallop with hounds in a peaceful English county. Yet in the Indian sport-for all its excitement-you do not get the home surroundings, the stretching gallop over fences and grass, the keen air, the neighbourly pageant, and all the halo of Old Englishness that go to make fox-hunting the lovable sport it is. Indeed it is only after testing other sports that you really appreciate to the full the beauty of this more homely one.

I suppose that in all the notable events of a man's life he remembers his first better than any subsequent experience. On me personally my first hog-hunting day is very indelibly impressed : not that it was a specially eventful day as hog-hunting days go, 
THE SPORT OF RAJAHS

but the novelty of the sport appealed to me very forcibly, and the picture remains. I see now the sumny yellow grass jungle, and the brown, strongshadowed coolies beating through it with their discordant jangle of cries and drums. Suddenly a "sounder" of smallish pig tumble out and file away across the open. My first view of wild pig, and a most disappointing one! Was this, then, the "mighty boar" they talked of so much? But a moment later a form, that at first looked like that of a donkey, caught my eye as he stood surveying the country from the edge of the jungle. This was a boar. He was watching one of our keenest beginners restlessly hovering about in a way that would have successfully headed back 
THE SPORT OF RAJAHS any timid-minded animal; but this boar was an old warrior; with an inquisitive look he stepped into the open and trotted towards our trio ; a moment later he started into a louping gallop with ears pricked forward and head low, and before our friend could manage to turn his spear in the enemy's direction the pig had dashed in, cut his horse's legs from under him, and had sent steed and rider rolling in the dust. Then he turned with a knowing shake of his head, and trotted gaily back to the cover, whence all further persuasion failed to move him.

Later on a party of us, all griffins, got away after a full-sized pig; in turn we managed to get up to him and to plant our spears in his body 


\section{THE SPORT OF RAJAHS}

and back; but we planted and left them there as beginners are prone to do, so that in a few minutes our pig somewhat resembled the fretful porcupine or a giant pincushion, while we could only ride near him emptyhanded. Whenever he faced us we fled, not exactly from fear, but from a desire to save our teeth and noses from the leaded spear-butts that nodded and swayed above him. Finally, getting tired of the sport, he dropped a spear, which enabled us to give him his coup de grâce. And then, to our horror, we discovered that he was not a "he," but a "she," after all! And so heinous a crime is the killing of a sow that we swore to keep our misadventure dark, although we had every excuse for I36 


\section{THE SPORT OF RAJAHS}

our mistake, since she looked all over like a boar and, as is often the case with barren sows, carried tushes. The crime happened many years ago, but the shame of it has hung over my life ever since, and now in confessing to it openly for the first time I feel a heavy cloud is lifted from my conscience.

Among the several spears hanging in honourable retirement on my wall there is one whose shaft is split for some three out of its six feet of length. And by that split there hangs a tale.

Two of us were out in camp together, more for shooting than for pig-sticking; still we had our horses and spears with us. Our tents were pitched in a delightful spot on the 


\section{THE SPORT OF RAJAHS}

high-wooded bank of the Jumna. Close to us lay our hunting-ground, rough grass country with occasional strips of thick jungle and frequent "nullahs" or dry watercourses. A preliminary glance at the ground overnight revealed signs of pig-in acres of upturned earth-so abundantly that we were forced to forego our shooting for the first day in favour of trying for a boar instead.

Thus the early dawn found Naylor and myself posted at the point of one of the covers, while the coolies began to beat it from the farther end. Waiting in a state of keen expectancy, we could hear their shouts drawing slowly nearer and nearer, and our horses' hearts were beating quick and tremulous between our knees. 


\section{THE SPORT OF RAJAHS}

Suddenly both horses fling round their heads with ears pricked; they are trembling in every limb with excitement. There he stands-not thirty yards from us-a grand grey boar with yellow curling tushes, and his cunning savage little eye glistening in the broad morning sunlight. $\mathrm{He}$ is listening to the distant sounds of the beaters, and does not see us. We-scarce daring to breathe-sit motionless as statues, with all our eyes, all our senses fixed on him. He moves a few paces forward, and pauses again to listen. Will he never go ?

At last an extra loud chorus from the approaching line decides him; he swings round, trots for a few paces, and then breaks into a rough 


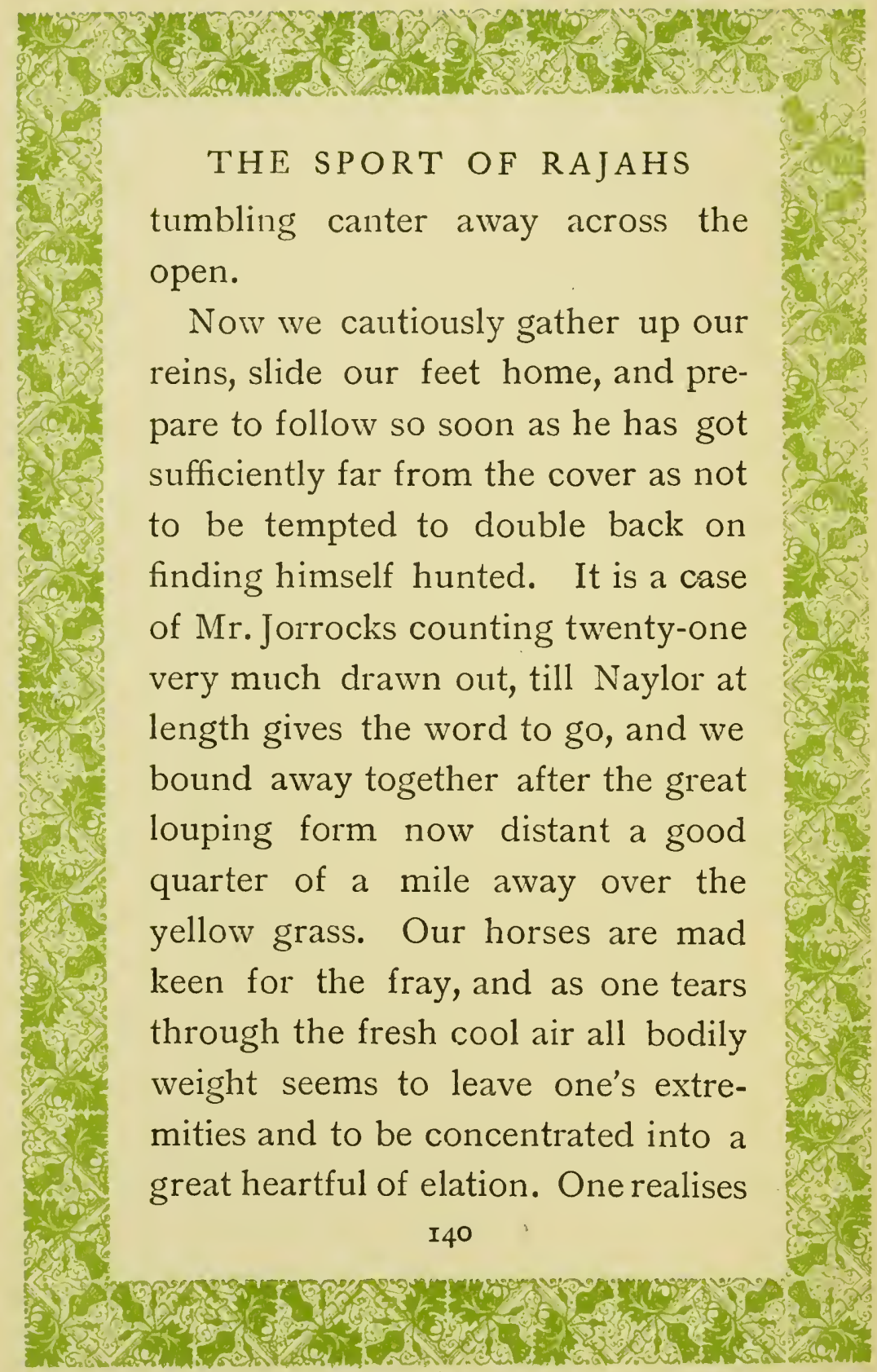




\section{THE SPORT OF RAJAHS}

then how good it is to be alive. On we go with little to check our pace but an occasional grip to fly; presently, however, my horse begins to show that, whatever my own impressions may be, he, at any rate, does not realise any material change in my actual avoirdupois, and I gradually find myself dropping behind Naylor in the race. Nearer and nearer we draw to the pig, and at last Naylor turns his spear (we are riding with the short or over-hand jobbing spear) ready to take the first blood.

But there's many a slip. The old pig is still cantering along in his deliberate yet far-reaching stride, looking to a novice as though he had not seen us; but he knows, his ears are laid back, and one eye or the other 
THE SPORT OF RAJAHS is continuously glancing behind him to watch our moves.

At last Naylor's chance comes. Closer and closer he edges to the boar; an extra spurt, and he is nearly on to him. The boar gives a half-turn to the right, and quick as thought Naylor's horse has turned with him-but the boar's half-turn is but for one stride; in the next he whips round at a right angle to his former course, and Naylor's spearhead dives bloodless into the sand a yard behind him. Riding twenty yards behind Naylor I am able to turn my horse more rapidly on to the new direction, and I gain a good start by cutting the corner to head my quarry. As I approach his intended line the boar cocks his ears, 


\section{THE SPORT OF RAJAHS}

alters his course a point towards me, and, as though projected by some hidden spring, is suddenly close under my horse's girths. My spearpoint is just down in time ; by good luck rather than good management it plunges in between his shoulderblades, and I crash it down with all my force, while my horse cleverly jumps the snorting monster. But the spear is jammed in the boar, and as he rushes beneath me he tears it from my hand, and staggers onward with the shaft standing on him. Nor does he go far, for his blood is up, and when Naylor hastens gaily after him, intent to kill, the enraged old brute turns staunchly to him and, with every bristle pricked and tushes chapping, makes towards his enemy. 


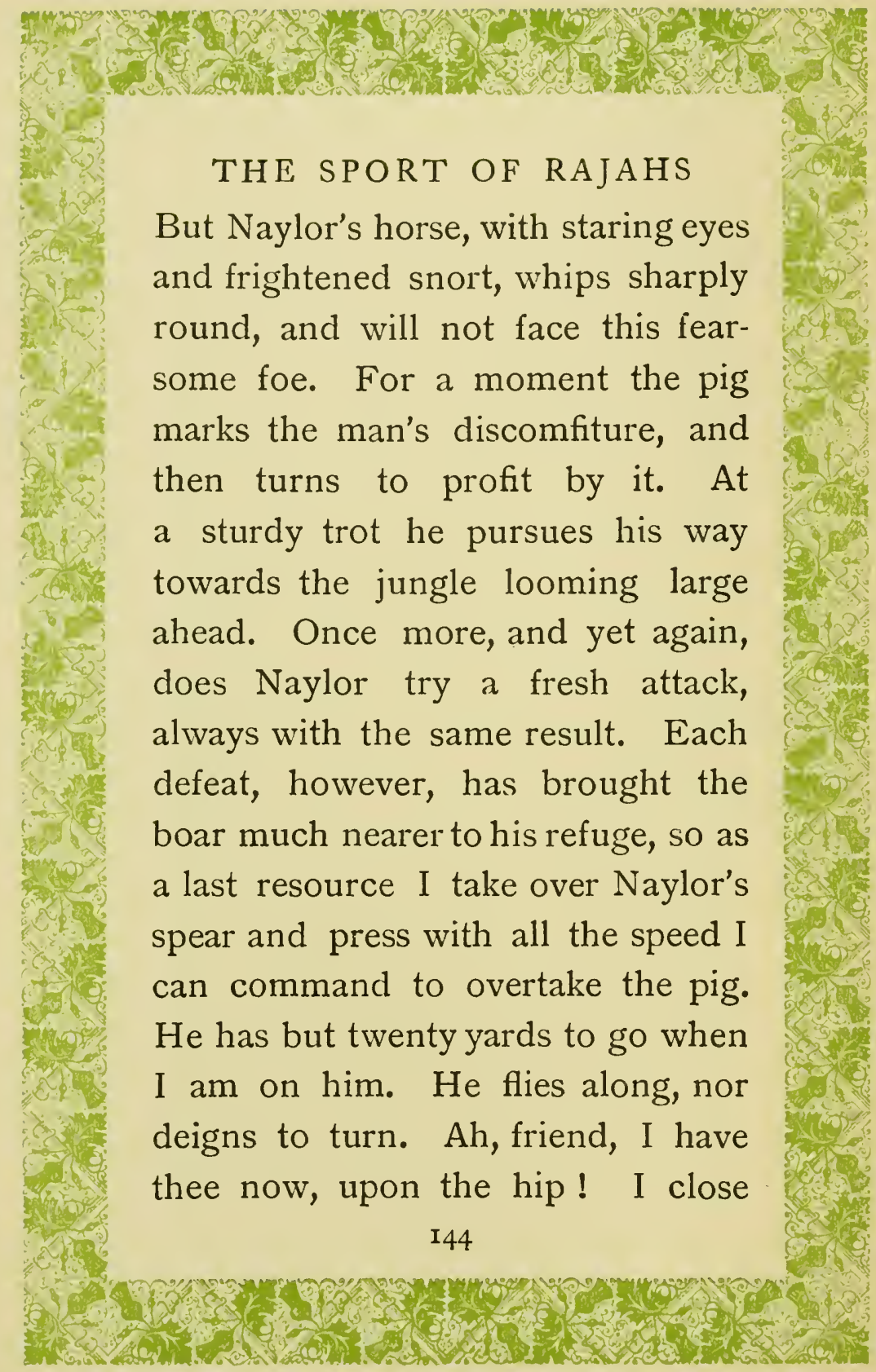




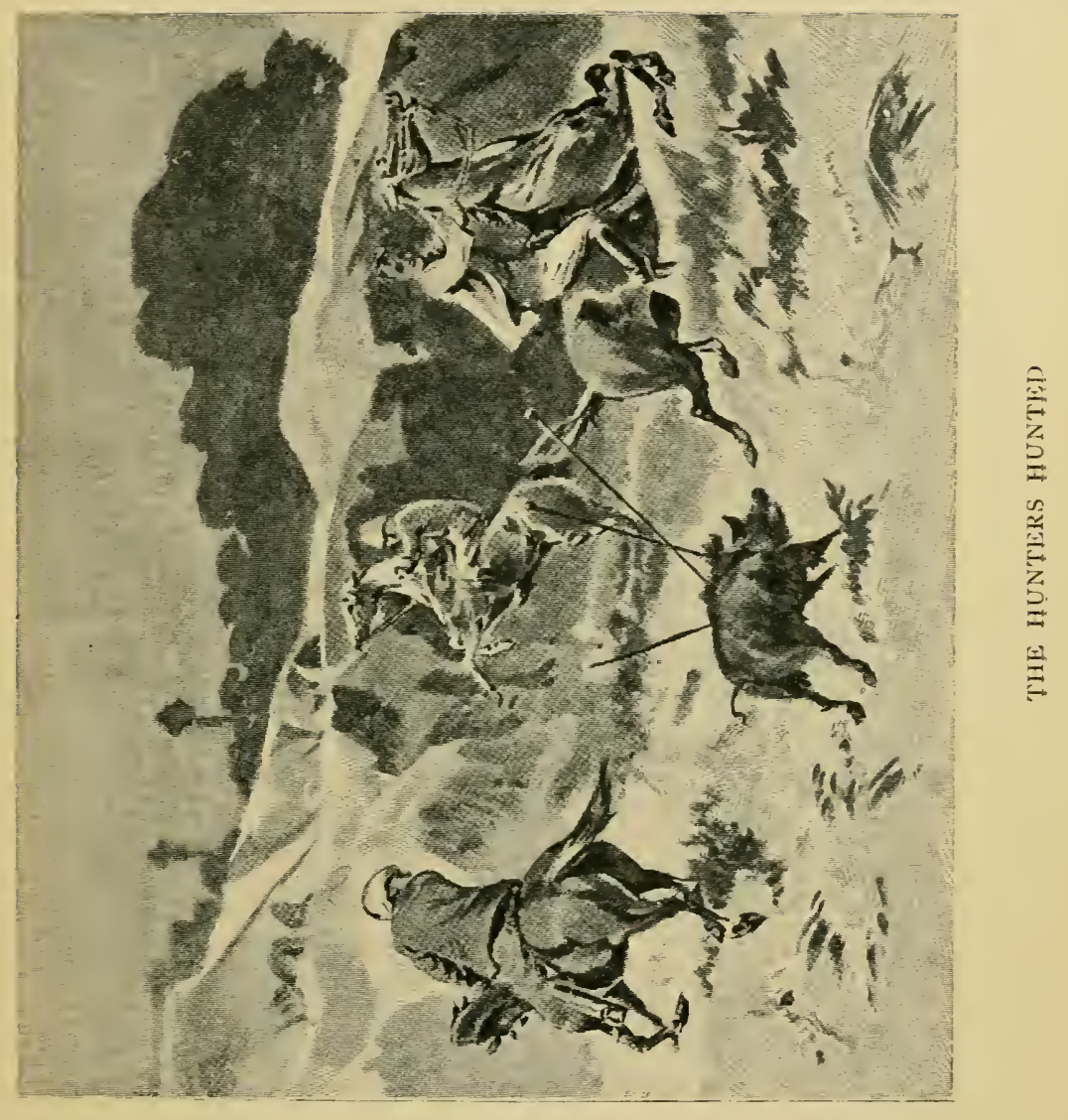





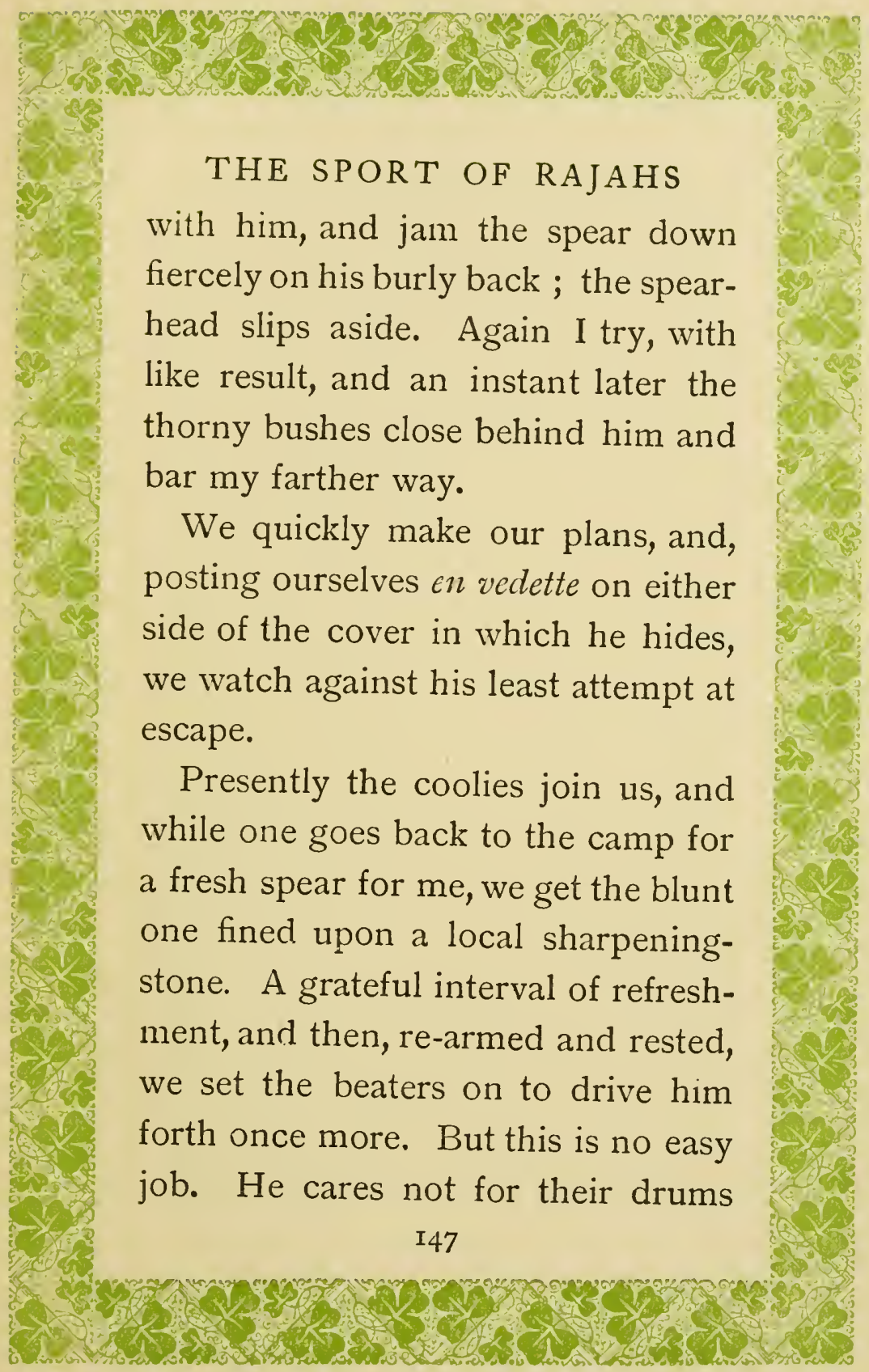




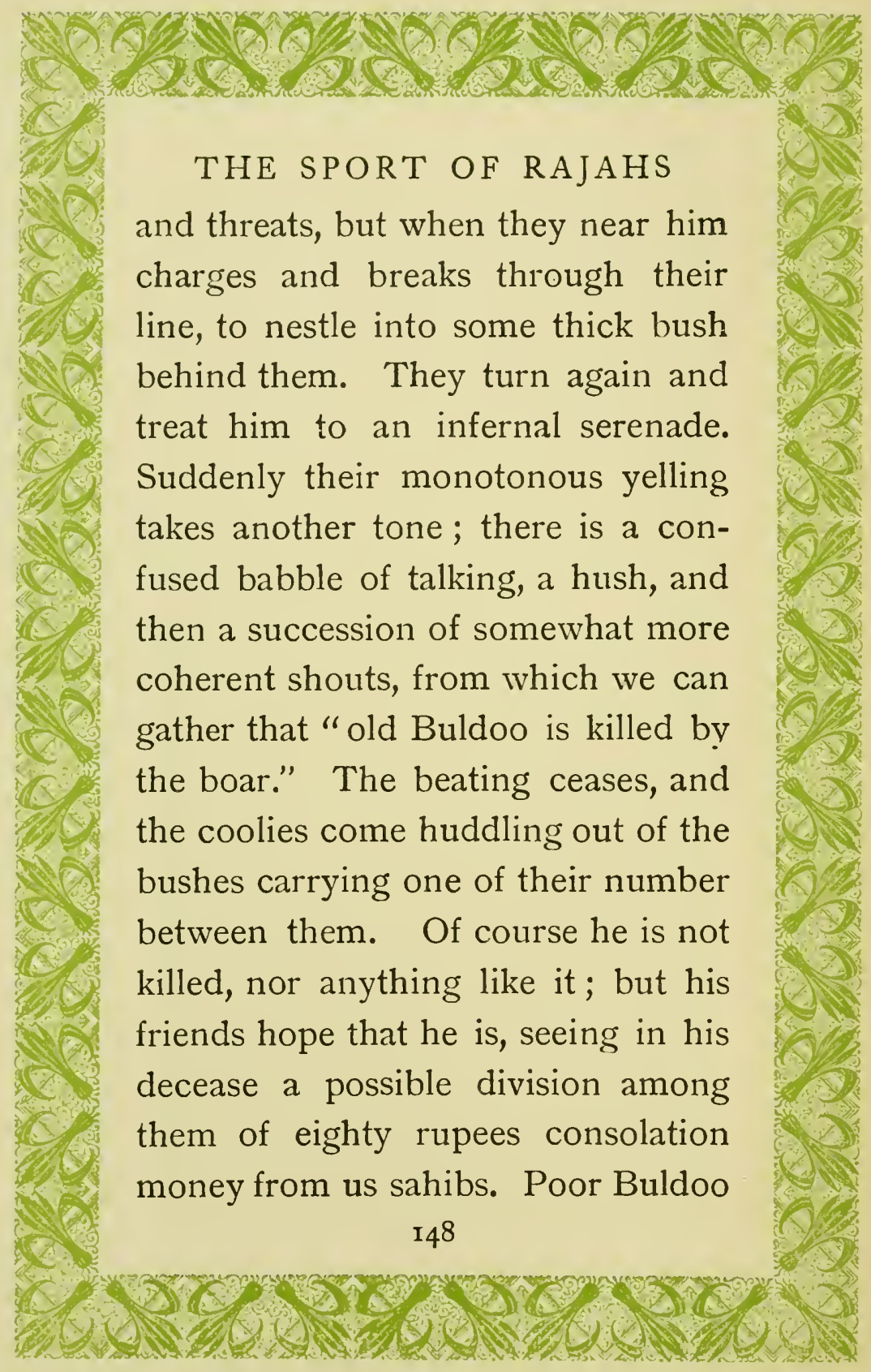




\section{THE SPORT OF RAJAHS}

has, however, a horrid circular gash inside the thigh, which has lifted a flap of flesh from a sufficient depth to show the bone. Such a wound on a white man would make a ghastly show, but not so on the darker Hindu skin, nor indeed is there much flow of blood. Such as there is we soon stop, and, using the needles and silk, carbolic, and compress from the handy little St. John's Ambulance wallet in our belt, we soon have hiru well patched up and homeward bound, comfortably installed upon a native bedstead from a neighbouring melon-gardener's hut.

Then for the first time my shikari steps forward, grinning, and holding in his hand the spear I had lost in 


\section{THE SPORT OF RAJAHS}

the pig. The boar, in charging Buldoo, had brushed close past himself, so that he was able to grip the spear with both hands and to wrench it out. But the shaft was split beyond repair. Once more the coolies form to beat the cover, and, whether it is some innate pluck or a stoical submission to fate that guides them, one cannot but admire the way in which they proceed, unarmed and on foot, to tackle a brute who has ten to one the best of them in the jungle. Naylor, too, dismounts, and is going in with them, spear in hand, leaving me to ride the boar should he break; but at this moment excited shouting from a shepherd on a neighbouring knoll informs us that our wily quarry has taken advantage I50 


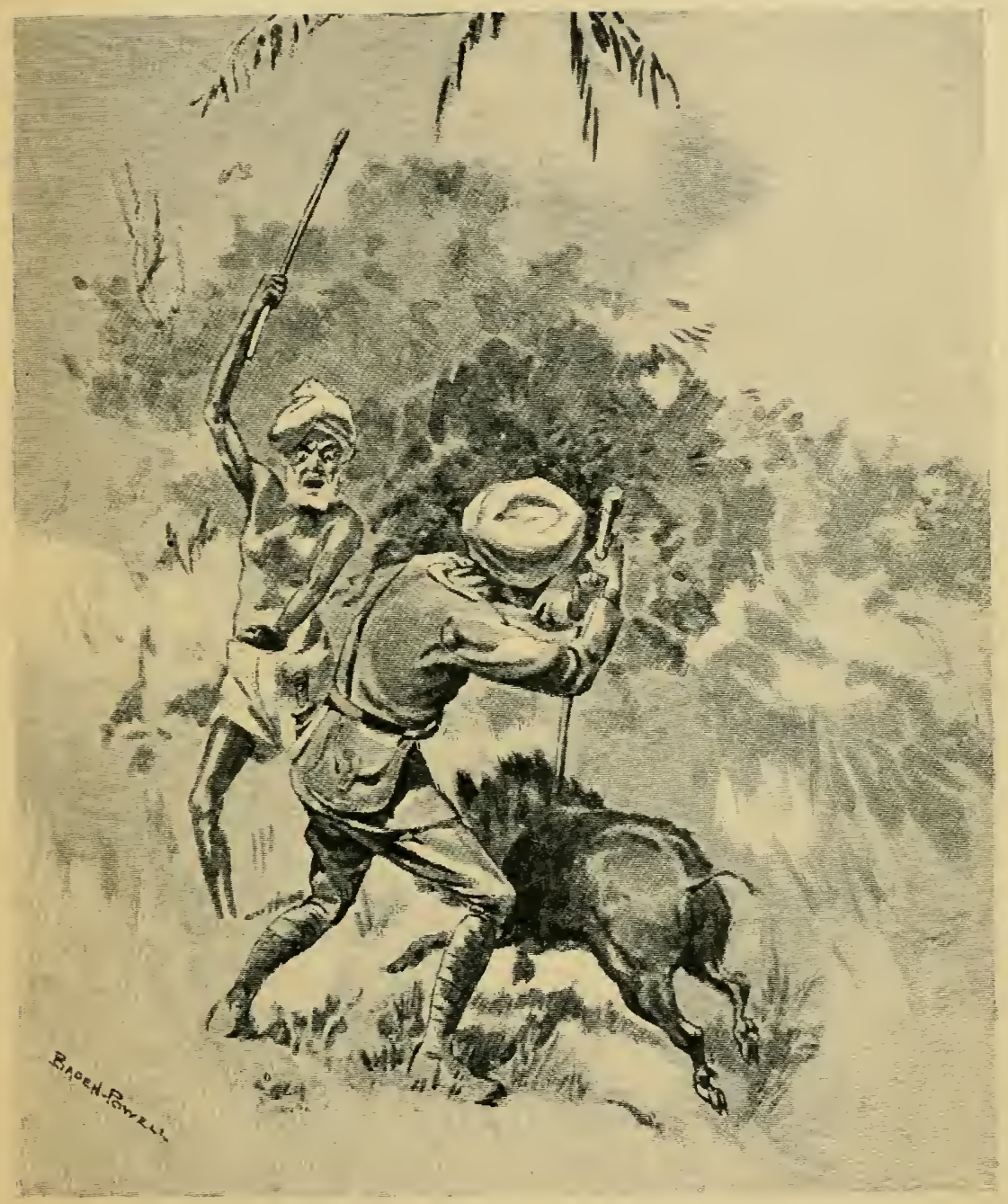

HE WAS ABLE TO GRIP THE SPEAR 



\section{THE SPORT OF RAJAHS}

of our preoccupation and has quietly slipped away. In a few seconds we are on the knoll, and thence we see our friend lobbing away across the plain (as Mr. Cruickshank used so expressively to describe it), "like a carpet-bag tumbling along end over end." For a second time we have a glorious but an all too short burst in the open, and again Naylor forges well ahead of me. However, the pig is in no humour to give us a gallop; when he finds that we are overtaking him, he stiffens his stride, and, dodging in his course for a moment or two, he suddenly turns and comes at Naylor "like a thousand of bricks," "with murder in his eye." But he has not reckoned on the sharpened spear, and as he bounds 


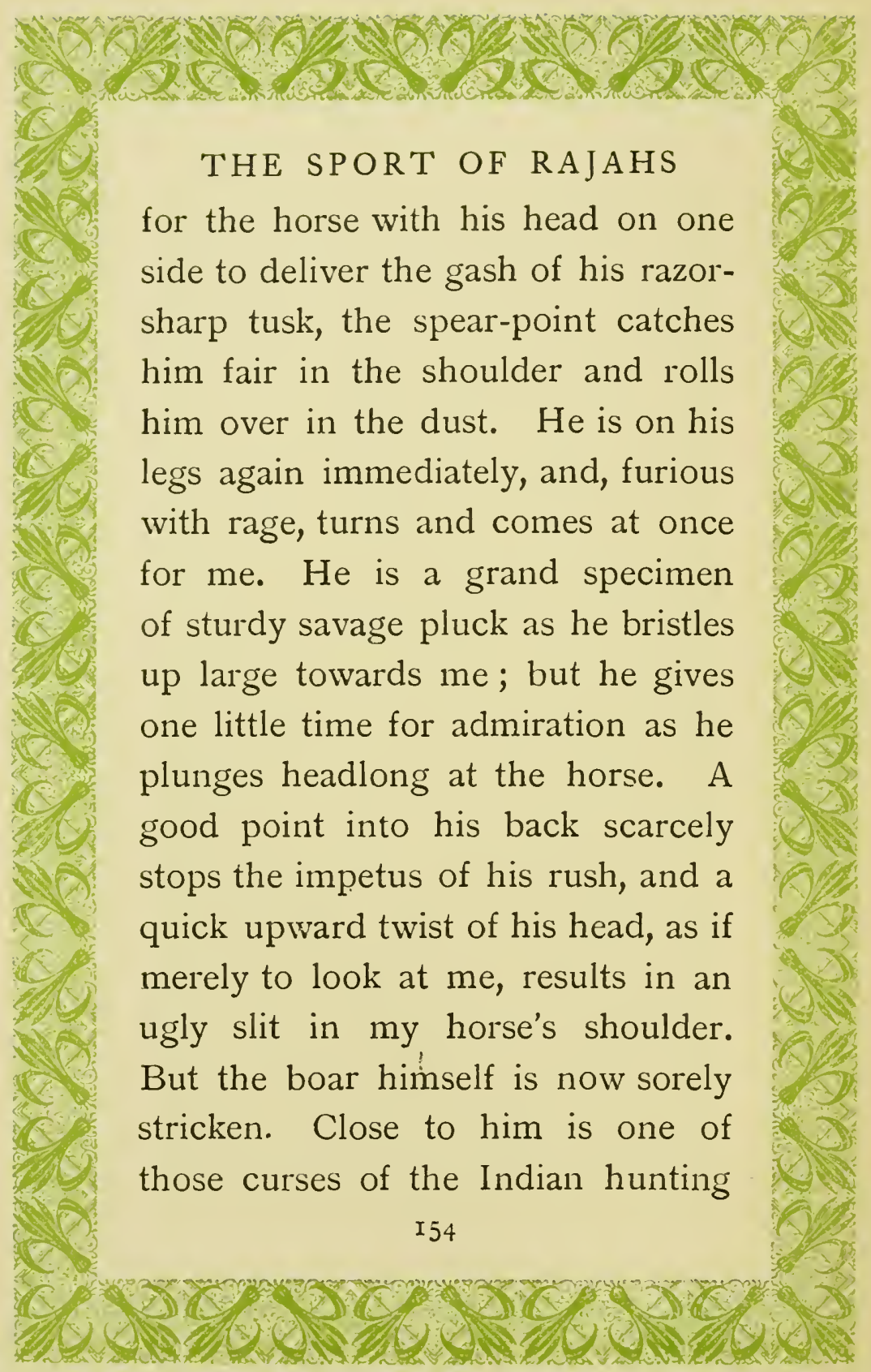




\section{THE SPORT OF RAJAHS}

countries, a deep "nullah" or dry watercourse some twenty feet wide and ten feet deep, with steep sides. Into this he plunges, and when we reach the edge we see him creeping into the cover of a big thorn-bush in the bottom. We note that immediately above the bush the sides have toppled in and have completely blocked the ravine. So, moving a few yards down the bank, we dismount, leave our horses, and scramble down, spear in hand, into the bottom of the nullah. Then we advance shoulder to shoulder towards the bush, and from a distance of ten yards or so we hurl two or three clods into it. Presently there is a rustle, and our friend quietly sneaks out on the far side, trotting lamely 


\section{THE SPORT OF RAJAHS}

up the nullah till he finds his road barred by the fallen walls. Then he turns and faces us, his little eyes sparkling red with rage, blood welling and glistening down his shoulder, his broad nose dry and dusty, and blood and slime dropping from his panting jaws. His picture is photographed on my mind, but the photograph is an instantaneous ore; for in a moment more his ears are pricked, his mane is on end, and he comes towards us at a shambling trot; at five yards distance he changes to a gallop, and rushes blindly at us. Our spears are low, there is a shock, we are both hurled back against the side of the ravine. Then in the cloud of dust we see the boar on his knees at our feet, I56 


\section{THE SPORT OF RAJAHS}

both spears planted in his chest and shoulder. He essays to rise, but falls back upon his side, and one more spear-thrust into his heart finishes off as game a boar as ever ran.

Well! this is not fox-hunting, but it is something that is very good.

In regimental orders one evening there appeared the notice that the regiment was to parade, mounted, next morning at daybreak, carrying full water-bottles and ten rounds of blank ammunition per man; rations to go out by cart; and, last but not least, "officers and troop sergeantmajors nuay carry hog-spears in place of swords." A most unique and eventful field-day resulted.

The jungle, a large tract of heavy grass and jhow (tamarisk) bush, was 


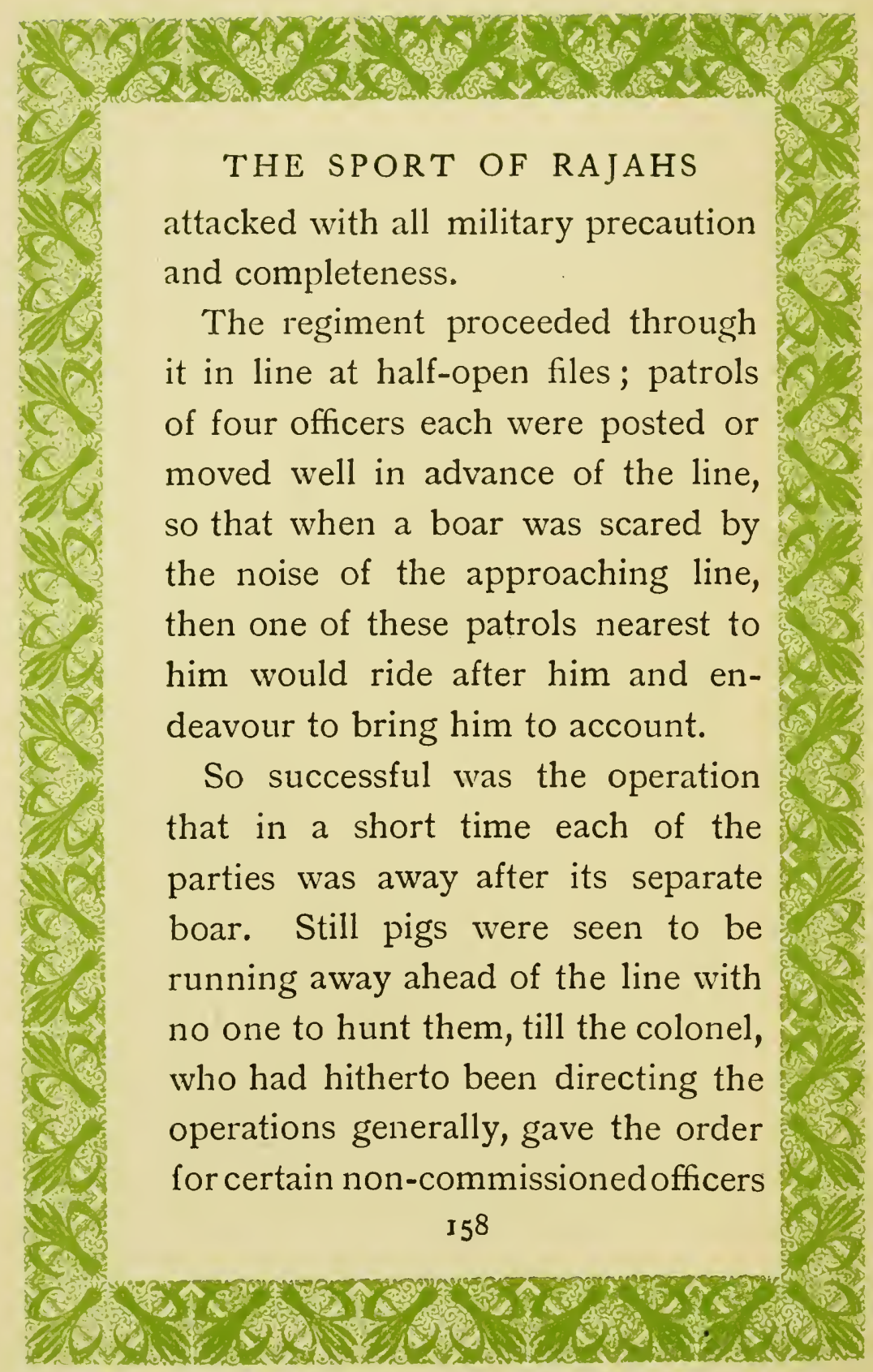




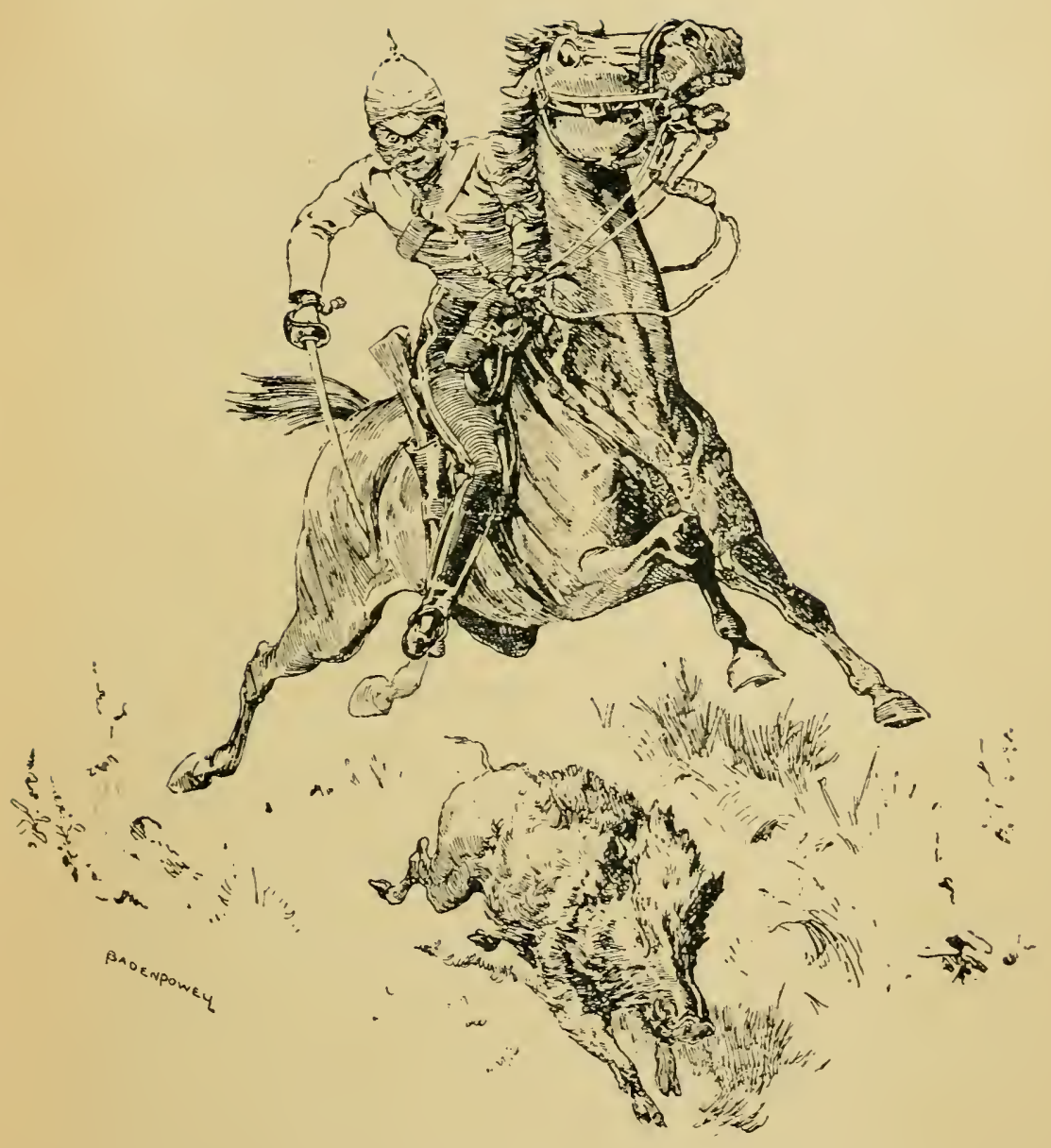

TOMMY ATKINS PIG-STICKING 



\section{THE SPORT OF RAJAHS}

to take patrols of men with them and see what they could do with their swords against the pigs. In a short time several of such parties were to be seen scouring across country in full pursuit of the common foe. To say that they enjoyed it would in no way express their excitement and delight.

They galloped here, they galloped there, They fought, they swore, they sweated.

In a word, they had a glorious time, albeit when the "Rally" sounded the bag-beyond those killed by the spear parties-was not a large one. Still, when all was over, the horses groomed and fed, and the men at their dinners and free to talk, the babel in the bivouac was almost ludicrous, since every man at once I 6 I 


\section{THE SPORT OF RAJAHS}

was keen to tell his tale of personal adventure with the Indian pig. Here one was stating how his troopmare, C 16 , had turned her tail upon the advancing foe, and with her ironshod heels had sent his front teeth rattling down his throat. And there another, a budding Munchausen, was relating how he stood the attack of " not only one, but four bloomin' swine, all of a go," and how all single-handed and alone he had beaten them off. It was a day that was talked of for months afterwards in the regiment; and though this one experience can have done no more than give the men a momentary taste of the ecstasy of a fighting gallop, pig-sticking is nevertheless par excellence a soldier's sport; it 162 
THE SPORT OF RAJAHS

tests, develops, and sustains his best service qualities, and stands without rival as a training-school for officers ; nor is it ever likely to languish for want of votaries so long as boars and Britons continue to exist. 


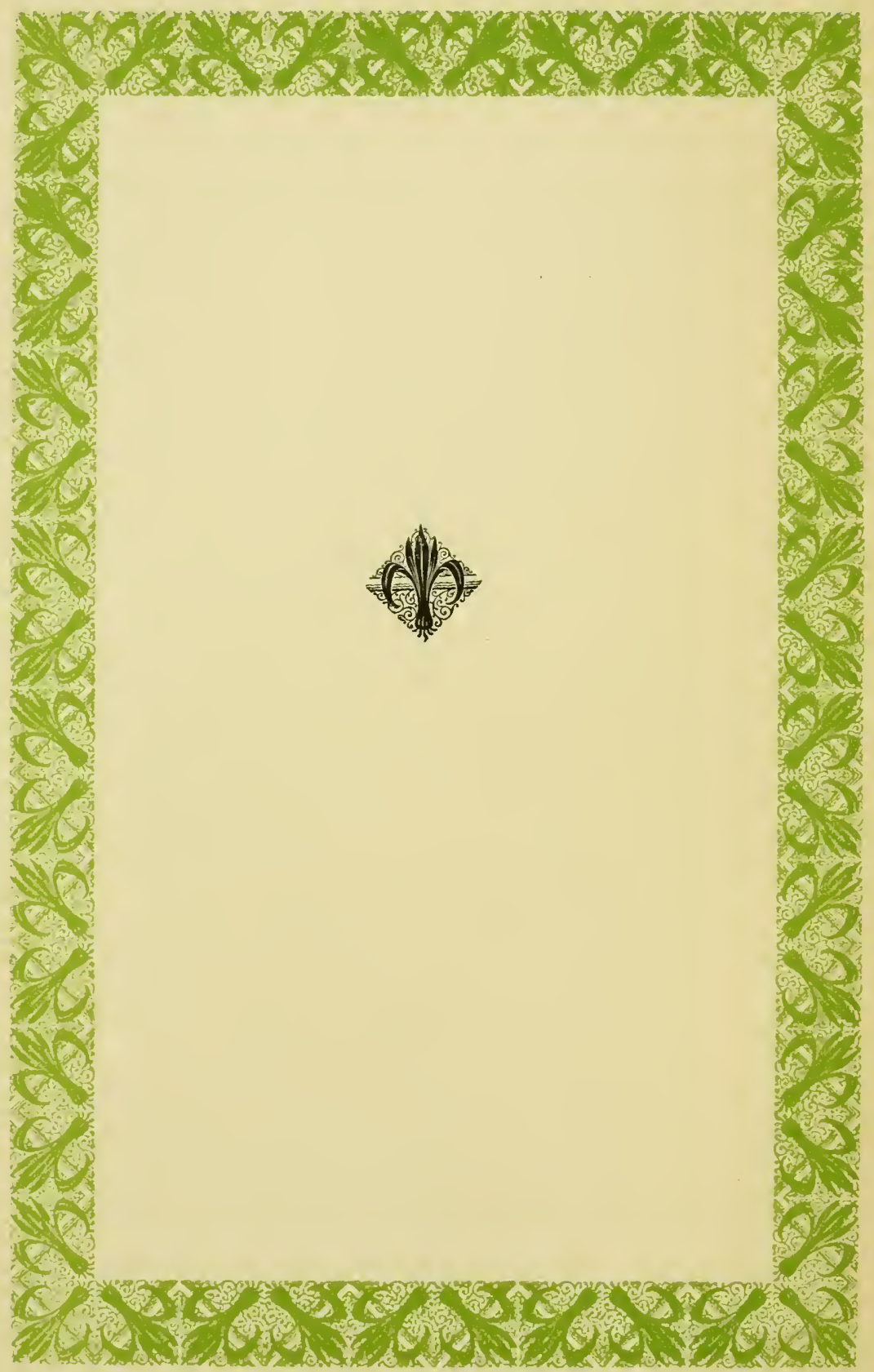




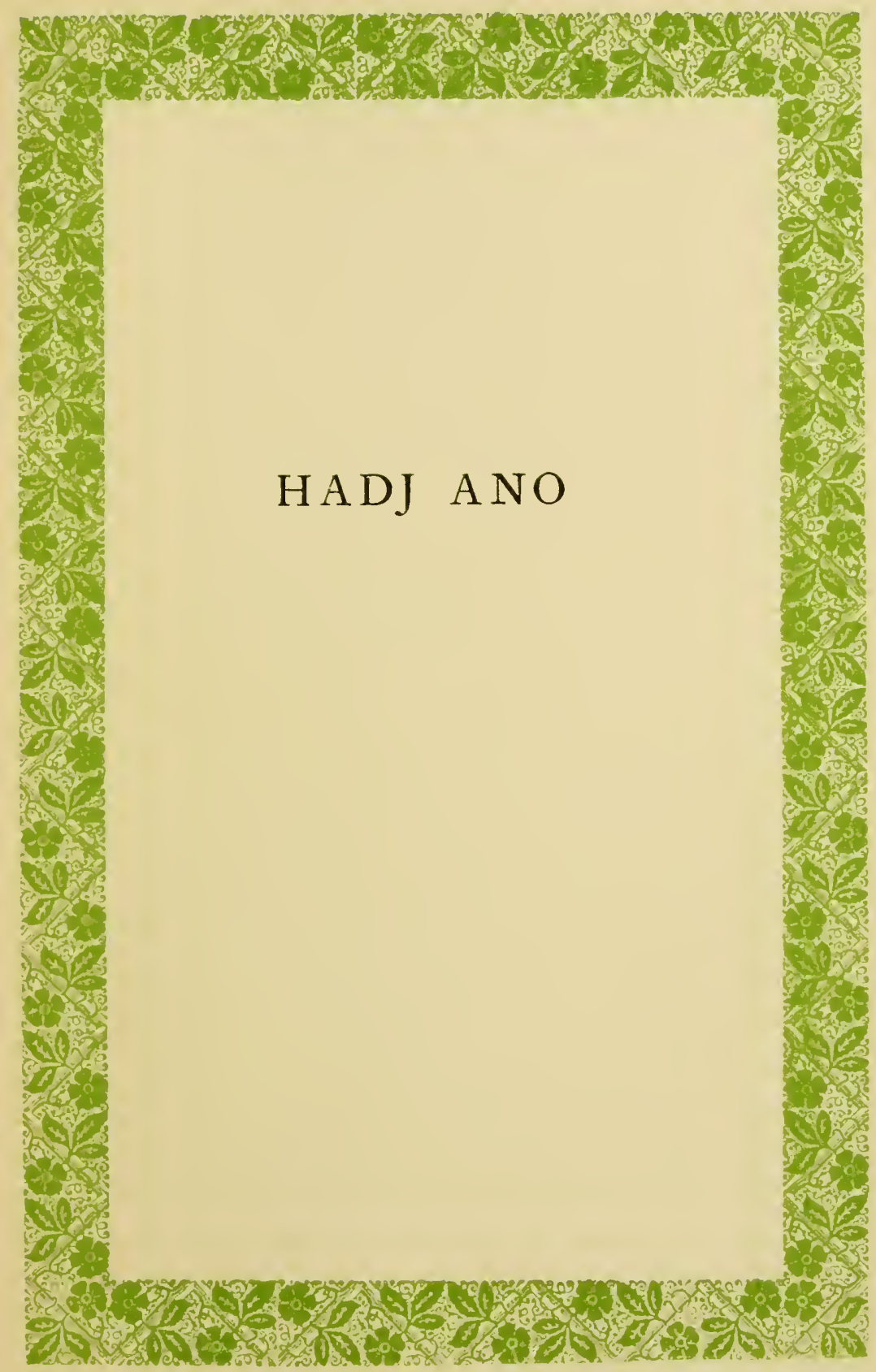




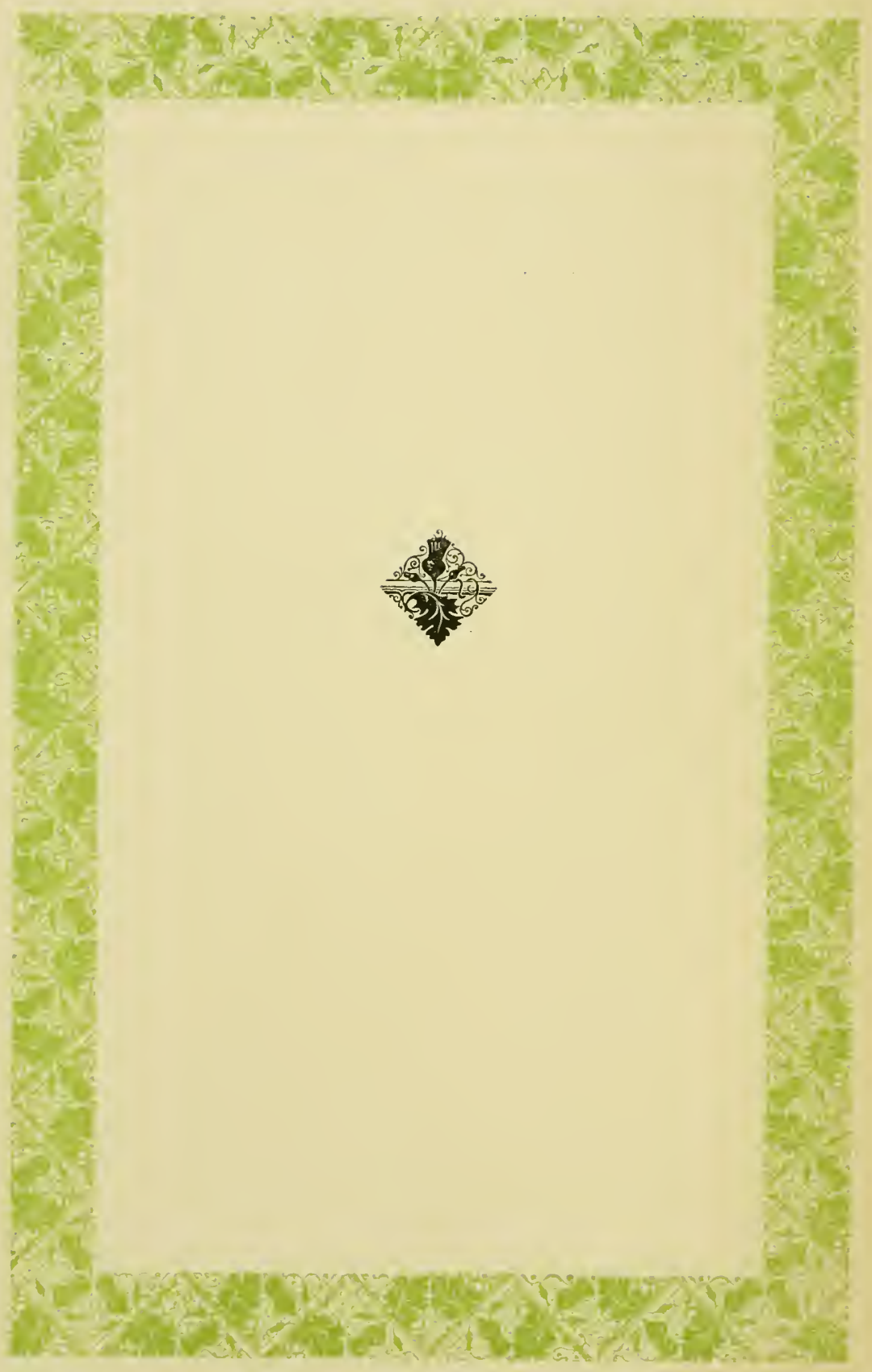




\section{$\mathrm{HADJ} A \mathrm{ANO}$}

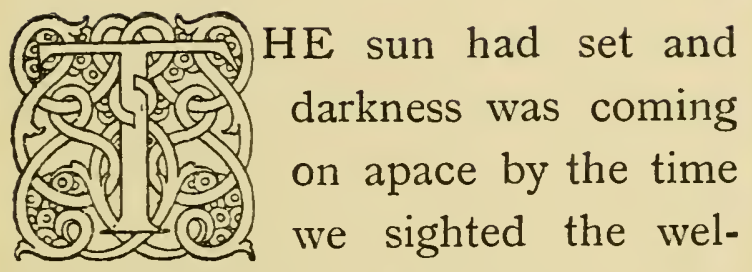

come lights of Brown's farm.

It was the second evening after landing in Tunisia, and the previous two days had been spent in journeying hither from Bizerta, through delays incident to mud, swollen rivers, poor mounts, and erratic guides.

"We" consisted of my interpreterservant and myself. He was a MalI67 


\section{HADJ ANO}

tese whom I had taken on at Bizerta on the recommendation that he knew Arabic and had been a fireman on board an English steamer. He only joined me just as I was starting on the march with my two ponies. I presently found that his Arabic was merely the Maltese dialect of it, and his English was limited entirely to such words as he had been accustomed to hear in his capacity as stoker; he had a very fairly complete vocabulary of oaths, and a few such phrases as "Stoke up," "Bank the fires," "Go ahead," "Stop her," and so on. It is true he had one extraneous English sentence, "She walks in the street," but this he used more as a form of salutation than anything else. 


\section{HADJ ANO}

"Stoke up" came to mean, with us, "Pack up and march" ; "Bank the fires" implied we might halt and encamp; and with this limited language, eked out with signs, we got along very well-all things considered. At any rate, we succeeded in arriving at the right place-wet and tired, it is true, but satisfied in the result.

On reaching the farm I found a note from Brown bidding me welcome, and explaining that in his enforced absence in Tunis two French officers, who were also guests of his, would be glad to help me in the matter of sport. The officers, in fact, received me at the door, and did the honours of the house with the greatest goodwill; 169 


\section{HADJ ANO}

but I missed from the scene the familiar form of Hadj Ano, whom I had known there on previous visits. He was an educated, high-caste Arab, who acted as farm bailiff to Brown. He was an Algerian Arab, and therefore a sportsman and a gentleman, and very far superior to the more servile local Tunisian natives.

The following morning, soon after dawn, saw us on our way to the snipe ground which lay at the foot of Jebel Ishkel. This was a mountain whose purple crags rose high above the plain, very much like Gibraltar in appearance.

What curiosities to me my French companions were! And I, no doubt, was equally an object of interest to I 70 


\section{HADJ ANO}

them. Their get-up for snipe-shooting was their uniform képi and jacket, with baggy linen overalls, and capacious game-bags and guns slung on their backs, and they rode their corky, half-bred stallions in regimental saddles.

The open yellow grass plains and the distant rounded mountains, in the crisp, clear atmosphere of the early morning, brought out a strong resemblance between this northernmost part of Africa and its southern extremity. As I jogged along with my two foreign companions, I seemed to be once more with my old Boer friends starting out on shooting horses for the veldt. But instead of the silent whiffing of Boer tobacco there came from my com- 


\section{HADJ ANO}

panions an incessant jabber, and a string of questions as to whether, in passing through Paris and Marseilles, I had seen this or that singer or danseuse, and what were the latest stories now being told.

This seemed to be the only interest, not only of this pair, but of half the officers one met in the colony. My present friends were a captain and his subaltern, both of them far older than would be the case in the similar grades in our army, and the captain was pretty well furnished with adipose tissue. Probably both of them had risen from the ranks; at any rate, their intellectual training was not of a very high order, and their ability as horsemen was on a par with it. 


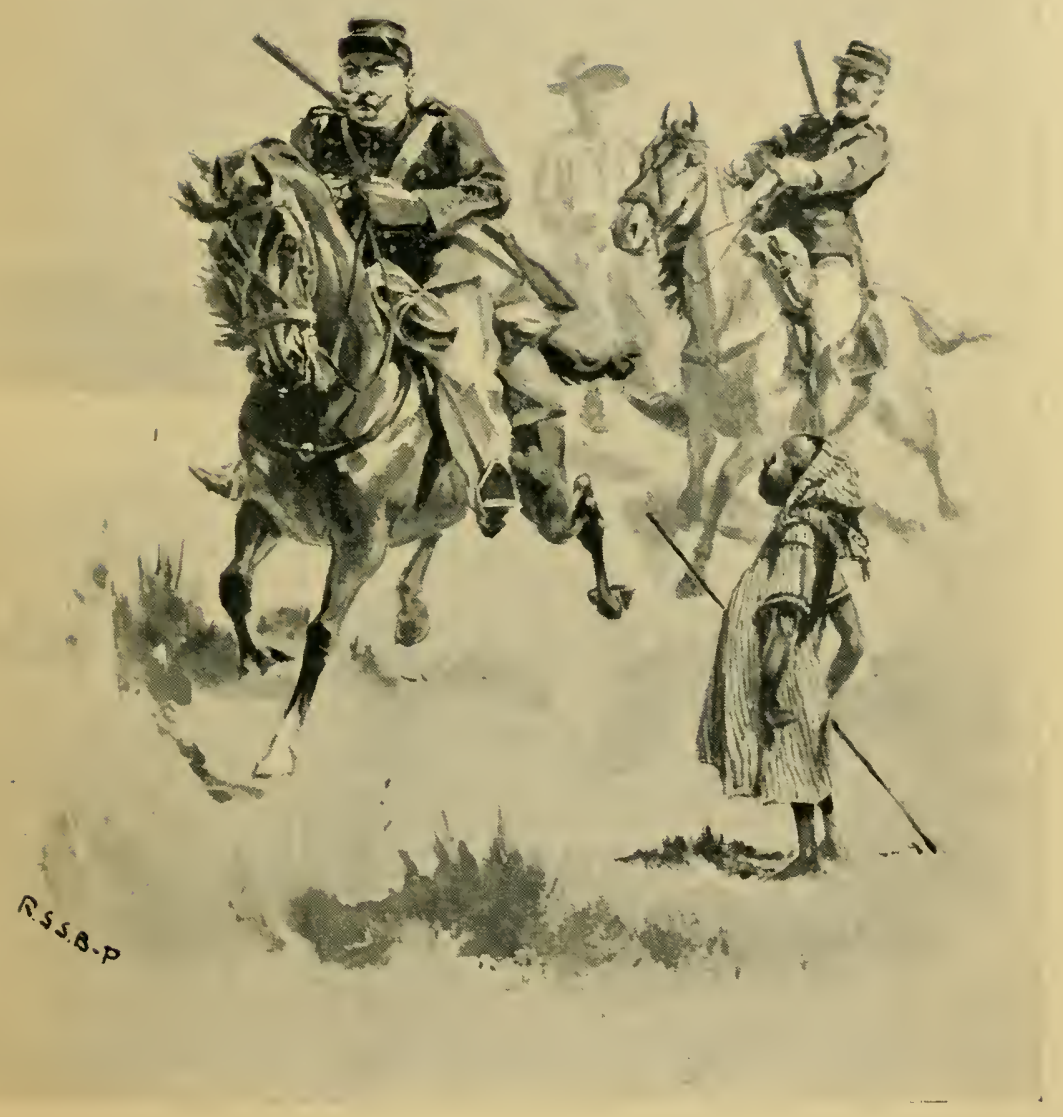

THE CAPTAIN, WHO WAS LEADING, PUSHED IN FIRST 



\section{HADJ ANO}

Presently we reached a river which had to be crossed before we came on our ground; it was about fifty yards wide, and just fordable by a man on horseback. The captain, who was leading, pushed in first, while Pierre, the subaltern, jibbed on the bank. As the captain's horse began to clamber up the far bank he placed his back at such an inconsiderate angle as to permit of the rider slipping off over his tail into the muddy stream. Having thus deposited his burden, the horse turned round and recrossed to rejoin us. As he ranged up near me I caught him and led him over again. Meantime Pierre was still niggling vainly at his mount, which steadily declined to brave the water, and even- 


\section{HADJ ANO}

tually I had to go back and fetch him along.

At last we arrived near the snipe ground, and, when we had offsaddled and tied up our horses, we started to walk the bog in line. We had hardly taken our places before the birds began jumping up in front of us, and the promise of sport raised our spirits to the highest; still, the birds were wild, and at first my shots were few and far between. Not so those of the Frenchmen, who fired on sight at every bird, distance being no object. But suddenly our sport was interrupted: a fiendish noise of neighing, screams, and snorting rose from the group of bushes where we had left our horses. The captain, who was nearest to that

$$
176
$$




\section{$\mathrm{HADJ} \cdot \mathrm{ANO}$}

point, climbed on to the intervening bank, and, giving a mighty yell, dashed forward in the direction of the noise, quickly followed by Pierre and myself. And then we found that Pierre's horse had slipped his headcollar and the captain's had broken away from the twig to which he had been tied, and the pair of them were now having a good set-to-hoof and tooth-as hard as they could go. It was a great fight, and was all the more amusing to watch, as the two owners kept skipping round, at a very safe distance, hurling stones and abuse with equal futility at their pugilistic quads.

At length, by using huge branches, we succeeded in separating and securing the combatants; and although 


\section{HADJ ANO}

they were covered with scratches, bites, and contusions-happily none of them were very serious-having tied them properly and out of sight of one another, we once more resumed our shoot. But it was in reality a hopeless game for as we walked on we had to wait continually for one or other of the Frenchmen. The fat one was a slow mover, and the other was desperately afraid of getting bogged; both talked incessantly at the top of their voices, and fired whenever they could find an excuse; consequently the snipe, of which there appeared to be any number, kept jumping up at eighty yards in front of us in a most disgusting manner. However, I noticed with great satisfaction that they did ${ }_{17} 8$ 


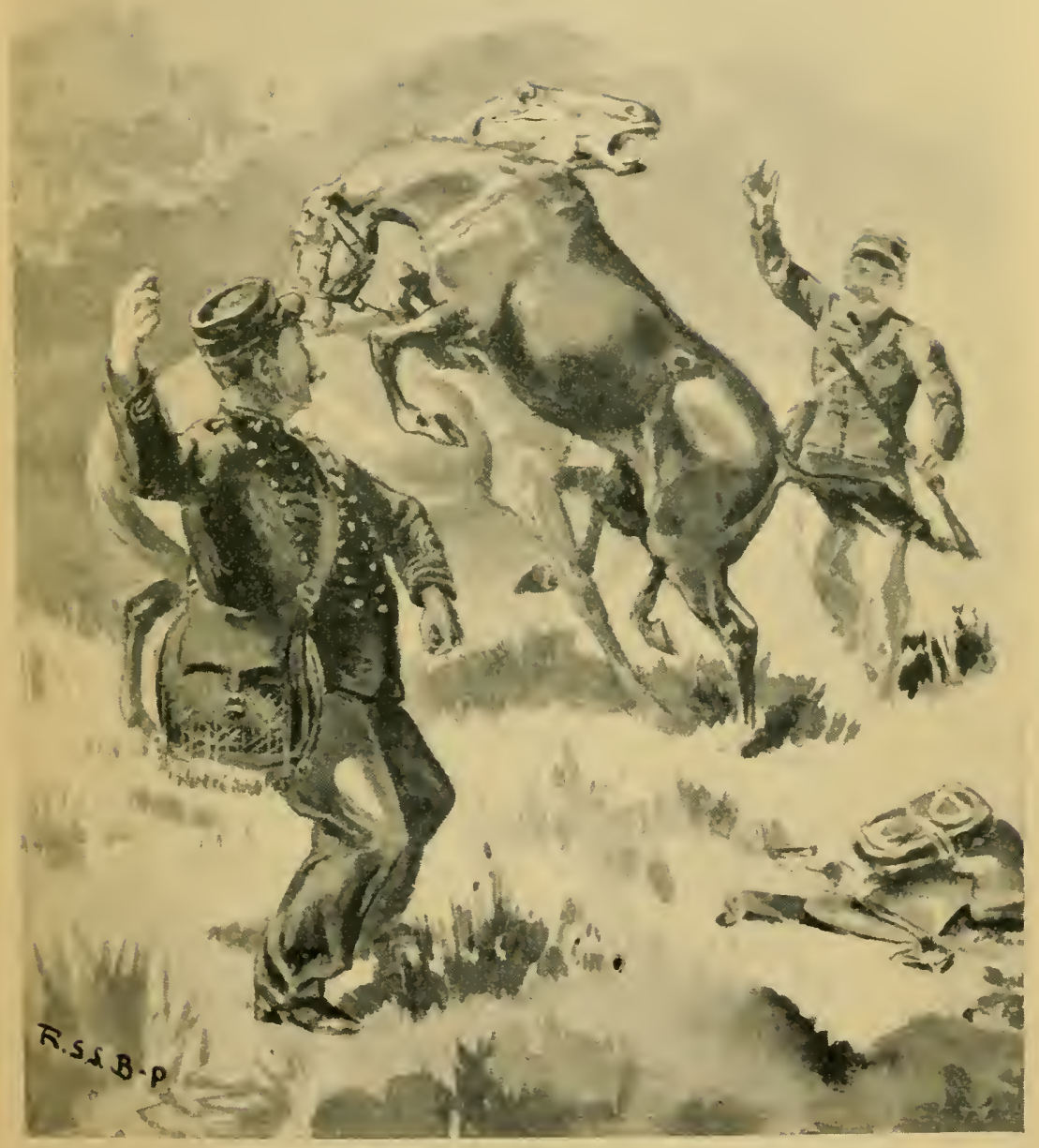

IT WAS A GREAT FIGHT 



\section{HADJ ANO}

not go far; the majority of them pitched again in the end of the long narrow bog we were walking.

Presently Pierre, through excessive caution, got bogged; finding the ground on which he was standing quaky and yielding, he had stood still, fearing to move in any direction instead of stepping off; and when he felt himself sinking his first act was to jam his gun-muzzle downwards into the mud, and his second to issue a succession of piercing yells which speedily brought us to his assistance. We soon lugged him and his gun from the slime-which, after all, was not by any means a dangerous bog -and deposited him on the bank to recover. Presently he reported himself fit to proceed, but he elected to I $8 \mathrm{I}$ 


\section{HADJ ANO}

move in line with us, remaining himself on terra firma. I earnestly begged silence now, as we were drawing up to the end of the beat, and for a short distance all went well save for the noisy floundering of the captain, who was rapidly getting rather done in spite of our slow pace through the hummocky reeds.

Presently a great common heavy hawk flapped his way lazily over-a shout of warning from Pierre, and bang! bang! bang! bang!-four barrels of snipe-shot at fifty yards' distance had the effect of making him smile as he winked the other eye. It did not make me smile, especially when one of them, noticing that I had not taken part in the volley, said, in a tone of remonI82 


\section{HADJ ANO}

strance, "Surely it amuses to shoot the large bird ?" But I had my eye the while on the smaller bird, Mr. Snipe, and I could see him slipping away in twos and threes, and soaring high for a distant flight.

At length, step by step, we drew up towards the end of the beat-it would soon be a matter for standing still to let the birds get up one by one: slower and slower we went. Suddenly Pierre on the bank began a hurried appeal at the top of his voice to us to come for a real chance of "gibier," and he started running along the bank past the end of the bog ; a moment later and the captain was pounding and splashing after him straight through the middle of the cover. Snipe were rising like a 183 


\section{HADJ ANO}

cloud of flies all round him; the air was full of their "scape" of alarm. For a moment or two I could not find words adequate to the occasion, and then I took myself, figuratively speaking, by the throat and held myself down till I was calmer.

And what are these two idiots after? I looked over the bank to see them stalking with elaborate precaution towards a bush on which were perched a flock of starlings! I left them to their fun, and walked back myself through the bog, and . succeeded in getting a few shots at birds we had walked over, and found myself with three couple in the bag by the time I got back to the horses.

Here I was presently joined by my friends, who had succeeded in getting I 84 


\section{HADJ ANO}

a brace and a half of starlings, half a couple of snipe, and the same number of greenfinches.

Then we saddled up and recrossed the river, this time without accident. Then when I proposed trying another little bog I knew of, the Frenchmen would not hear of it-for one thing they were evidently quite beat with their exercise up to date, and for another they argued that déjemner would now be awaiting us at the farm. So I determined to try the bog by myself, in reality much relieved at their determination.

I had not turned from them many minutes ere I noticed a small Arab evidently trying to overtake me. I waited for him, expecting he might have marked down some game near 185 


\section{HADJ ANO}

by, but he said not a word until he had come sufficiently close to touch my stirrup. Then, in a low voice, he asked in Arabic if I were English ; on my satisfying him on that score, he merely said, in a lower voice than before, "Hadj Ano," and pointed to a distant clump of trees. I guessed that my friend must be there, and had sent this mysterious little messenger to tell me. So, accompanied by the boy, I rode in that direction, and as we approached the place a figure came out to meet us, which I soon recognised as Hadj Ano himself. He was a fine, tall, well-proportioned man of about forty, with the typical high-caste Arab features. Except for a turban, he was dressed in European shooting clothes, and 


\section{HADJ ANO}

carried in his hand a gun belonging to Brown. He cordially greeted me (he spoke French like a Frenchman) and led the way to the grove. Here I found a delightful little camp of two Arab tents, one of which was occupied by the Hadji himself, the other by some three or four Arabs who were with him.

In a few minutes some of these men had taken my horse and were grooming and feeding him, while another was preparing some food for me.

After some mutual inquiries I asked the Hadji how he came to be camped out here instead of living in the farm as usual, whereat he laughed and said that he did not care for French officers, and while 187 


\section{HADJ ANO}

they occupied the farmhouse he preferred to camp outside; and, knowing the dislike the Algerians have for their French masters, I thought no more of the matter. He said he had heard of my arrival, and had sent the boy to bring me to him if I should be working alone.

We had an excellent déjeuner of Arab dishes, in which "khus-khus" (a kind of semolina and chicken curry) figured as the pièce de résistance, and after a short rest we started out for a bit of ground which Hadj Ano recommendedopen stony ground with patches of tufty, coarse grass and clumps of thorn bushes, through which there meandered a stream which every 



\section{HADJ ANO}

now and then opened out into a green, tussocky bog.

It was ground that might and, as we very soon found out, did contain many varieties of game. Shortly after commencing our beat, with two Arab boys as game-carriers, we put up a fine little covey of partridges some distance out of shot, and almost immediately afterwards the Hadji knocked over a hare very neatly. Then there fluttered up from a bush between us a woodcock, and crossing me gave me an easy shot which brought him into the larder. A little farther another hare fell to my companion. Then we came to a small hollow, evidently well watered, filled with thorn bush, rank yellow grass, and a few green bushes which looked 


\section{HADJ ANO}

like holly. Hadj Ano and I stationed ourselves outside this cover and sent the boys in to act as spaniels. Presently, with a silent whisk, a rich brown woodcock flitted past me, and then so suddenly changed his course as to escape the shower of shot with which I saluted him. But no less than three more birds came out of the same spinny, two to me and one to the Hadji, and these were all accounted for. As we went on a tempting reach of reedy swamp received our attention, and here we had some very pretty snipe-shooting. Alert they were as in the morning, but they did not fly far on the first rise, and my present companions, keen and silent, were very different from the noisy Frenchmen. As a Ig2 


\section{HADJ ANO}

consequence we soon began to run up quite a little bag. We had no dog, but slow and careful walking got the birds up nicely, and the Arab boys were as sharp as needles in marking and retrieving fallen game. Anon we came to a long and narrow belt of thorn bushes lining both banks of the streamlet. Hadj Ano took one side and I the other, the boys working along in the bush, tapping as they went. Four shots at intervals from Hadj Ano's gun began to make me impatient of my own silence, but at last a long bill rosewithin the thorns and came to my side, and gave an easy shot as he turned to wing along the side of the cover; almost where he fell another rose, and gave a long shot for my left barrel. I should 


\section{HADJ ANO}

probably have missed him had it been my right, but, as it was, he too bit the dust.

On and on we went, getting every now and then a shot at cock, until at length the sun began to sink towards his setting, and we had wandered far from camp. Then we turned and, as far as the light would allow us, shot our way back towards the tents. Out of a reedy pool we got a mallard and his mate, and a little farther on a woodcock, probably a wounded one, rose from bare ground at our approach, and fell, after a twisty flight, to my second barrel. Soon after the sun had set a whistle of golden plover sounded suddenly near, and as they rushed overhead we stopped a couple and a half. 


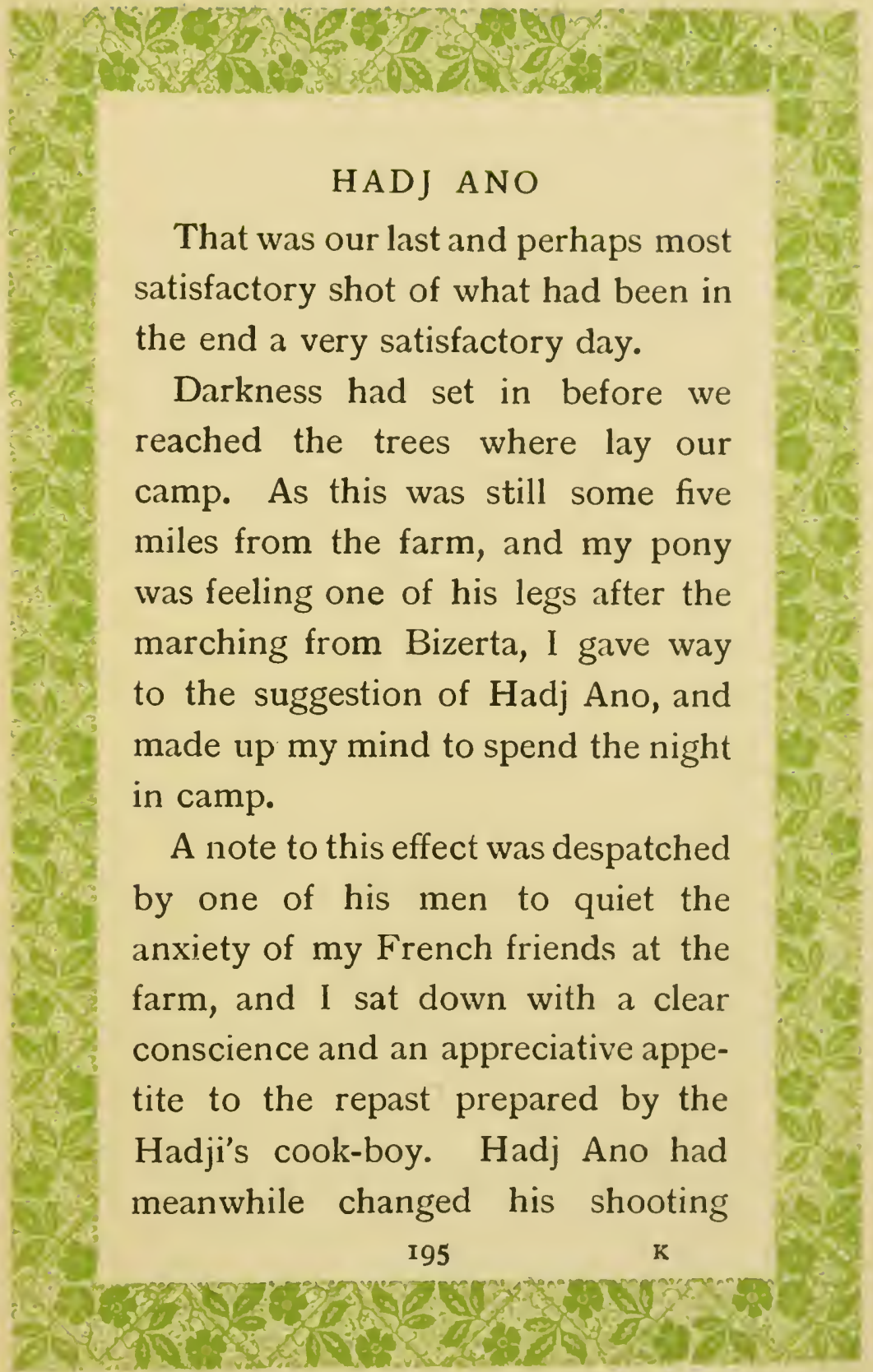




\section{HADJ ANO}

clothes for his native Arab dress, which he always wore at home.

Then followed one of those delights which only come too seldom into one's experience-to lie at one's ease in the cold, clear night by a warm and cheerful camp fire. The restfulness of it appeals to every joint in the tired sportsman's frame, while his mind is amused by the quaint tales and plaintive songs with which the Arabs pass away an hour or two.

Then, warm and sleepy, one rolls into one's blanket to sleep off all fatigue and gather fresh energy from the pure fresh air of one's bedroom under the stars.

Often during the night, as is my wont, I awoke to glance around, and 196 


\section{HADJ ANO}

every time I did so I saw a watchful figure sitting near, or standing looking out across the plain beyond the trees. It was only later on that I found out the reason for this vigil.

Early in the morning I shot my way back to the farm alone, for Hadj Ano laughingly declined to accompany me to see the French. men. We parted with a cheery hand-wave, meaning soon to meet again; but we have never met.

A few months after this I chanced to read La Dépêche Tunisienne, and came across a column describing how the police had made a raid on Brown's farm with the object of capturing "the renowned convict Hadj Ano." My friend, it appeared, 


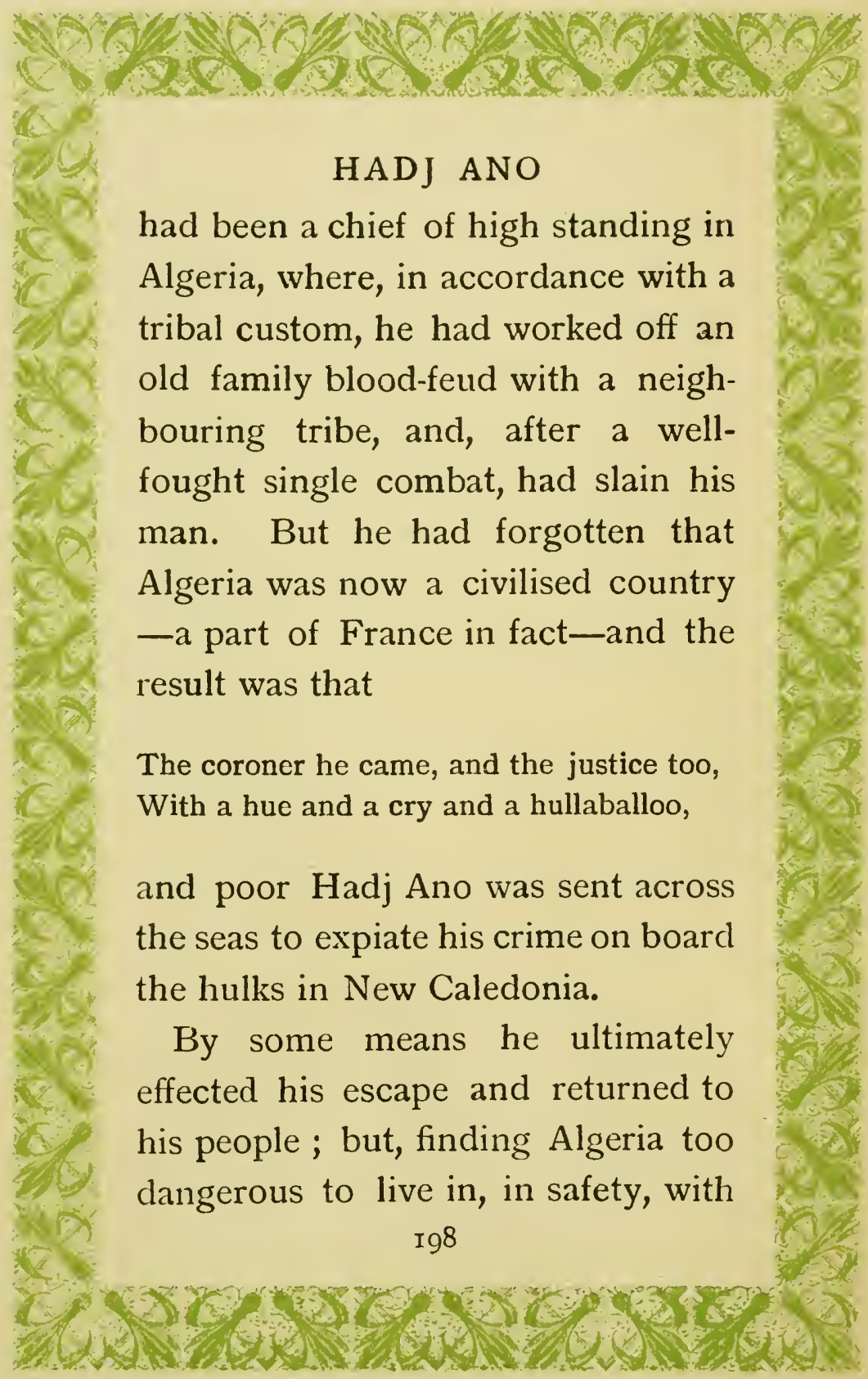




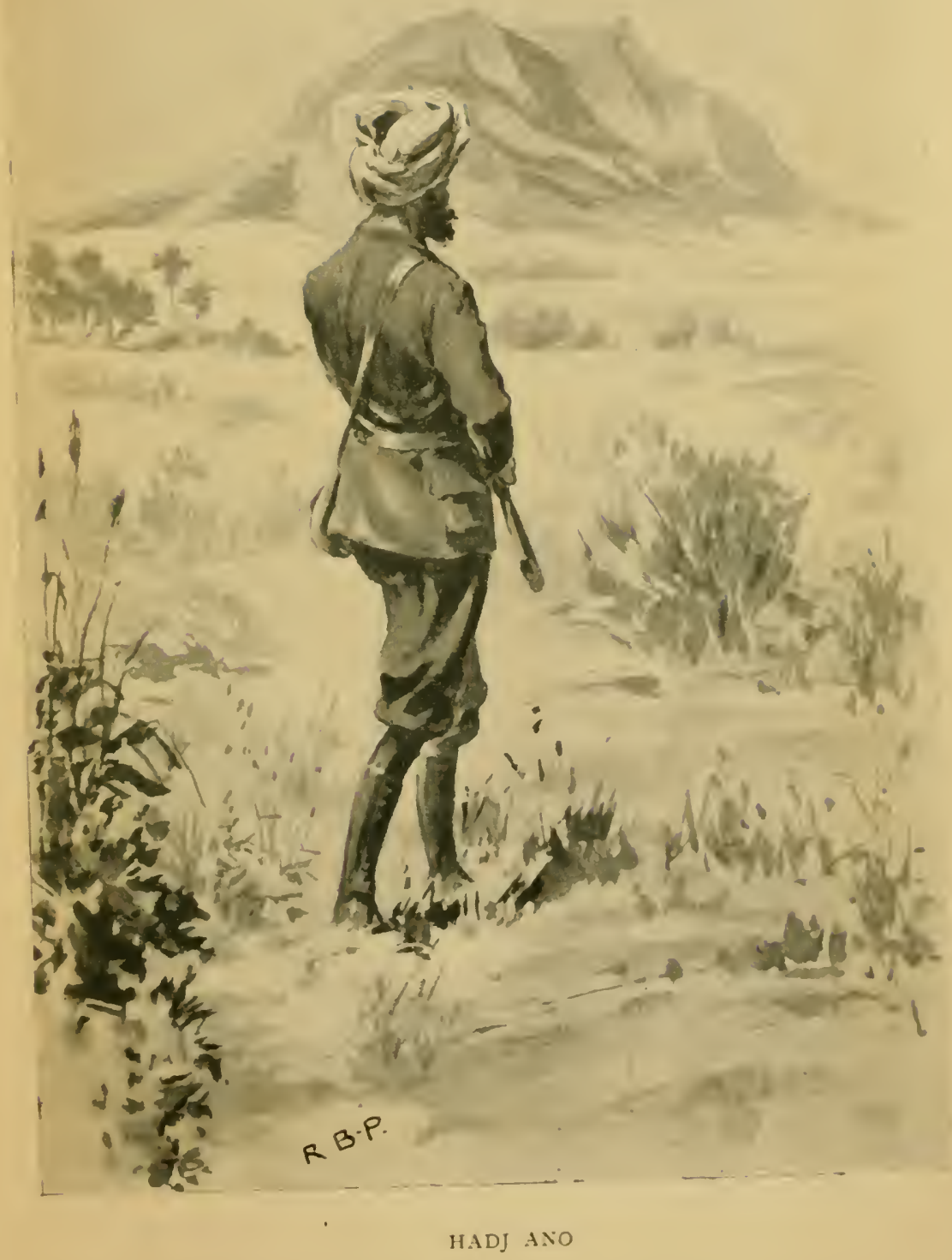





\section{HADJ ANO}

a few trusted followers he moved across the mountains into Tunisia. Here he made the acquaintance of Brown, and his sportsmanlike and gentlemanly character, combined with his intelligence and education, made him at once a useful bailiff and a pleasant companion on the farm. His faithful people watched over and guarded him, and the country Arabs for miles round knew his story and passed him warning when French officials of any kind were moving in the direction of Brown's farm. At length fate went against him. Somehow, whether by bribery or other means I have never heard, the police managed to keep their movements secret, and having surrounded the farm during the night, seized poor 


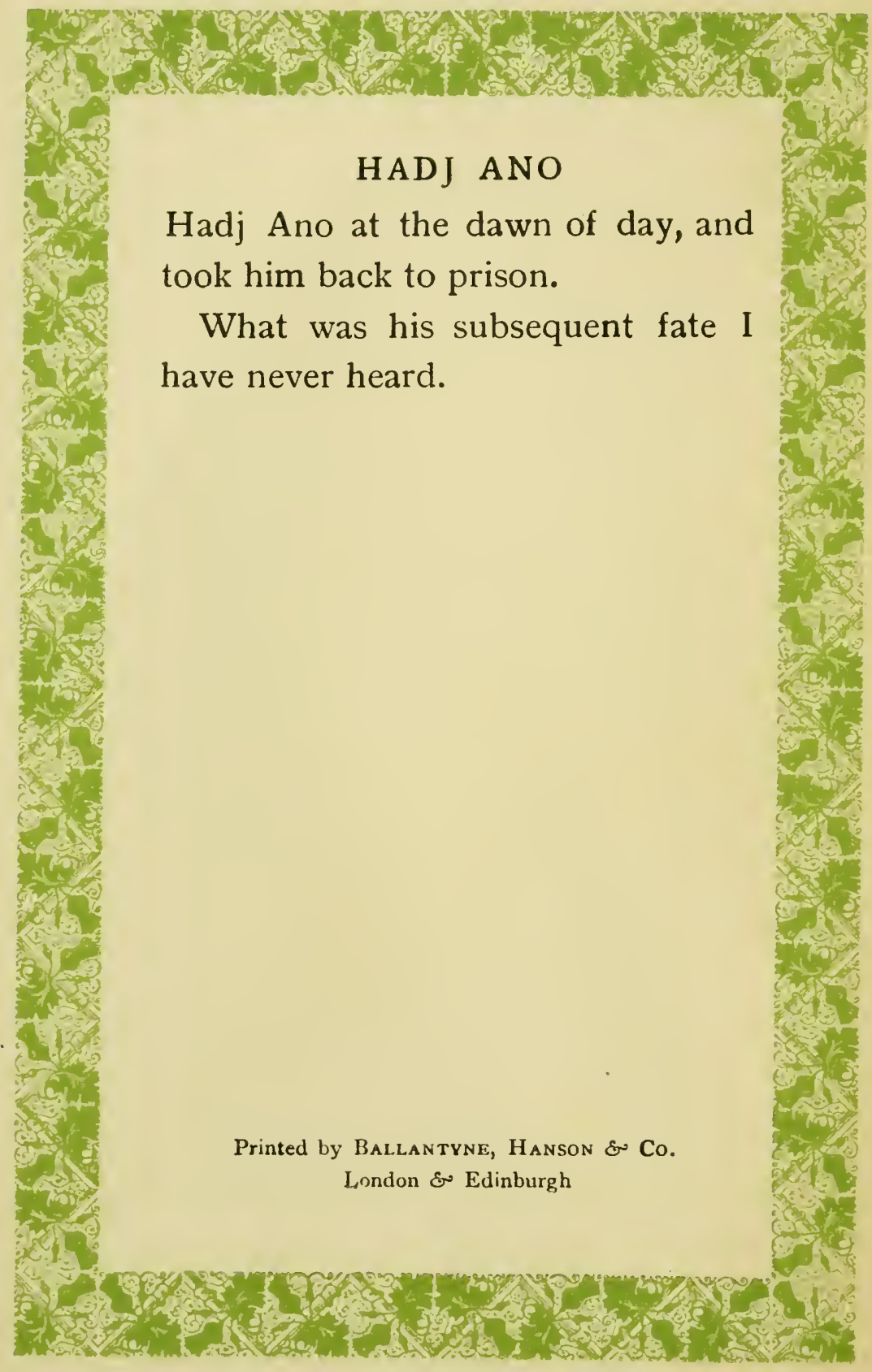




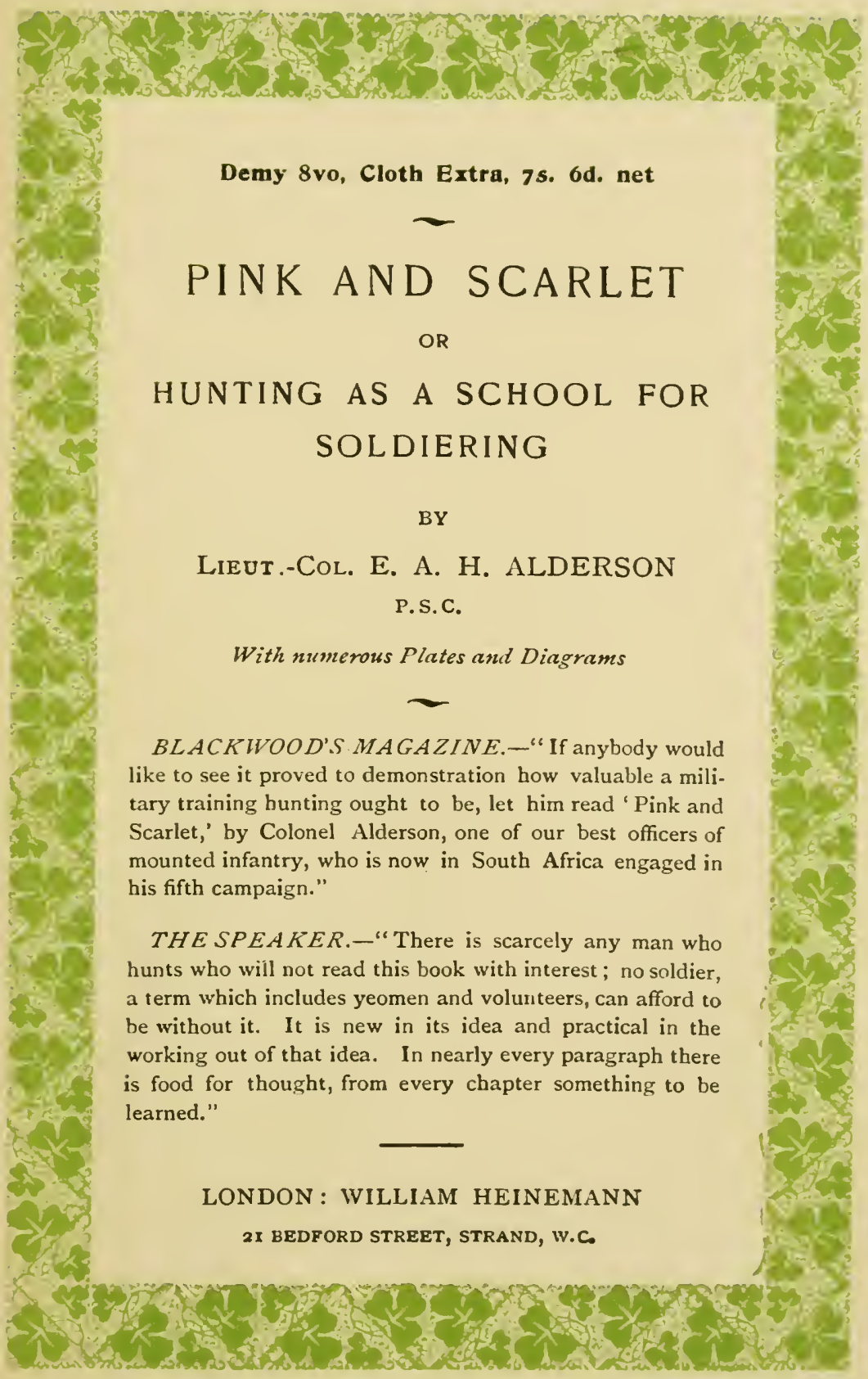




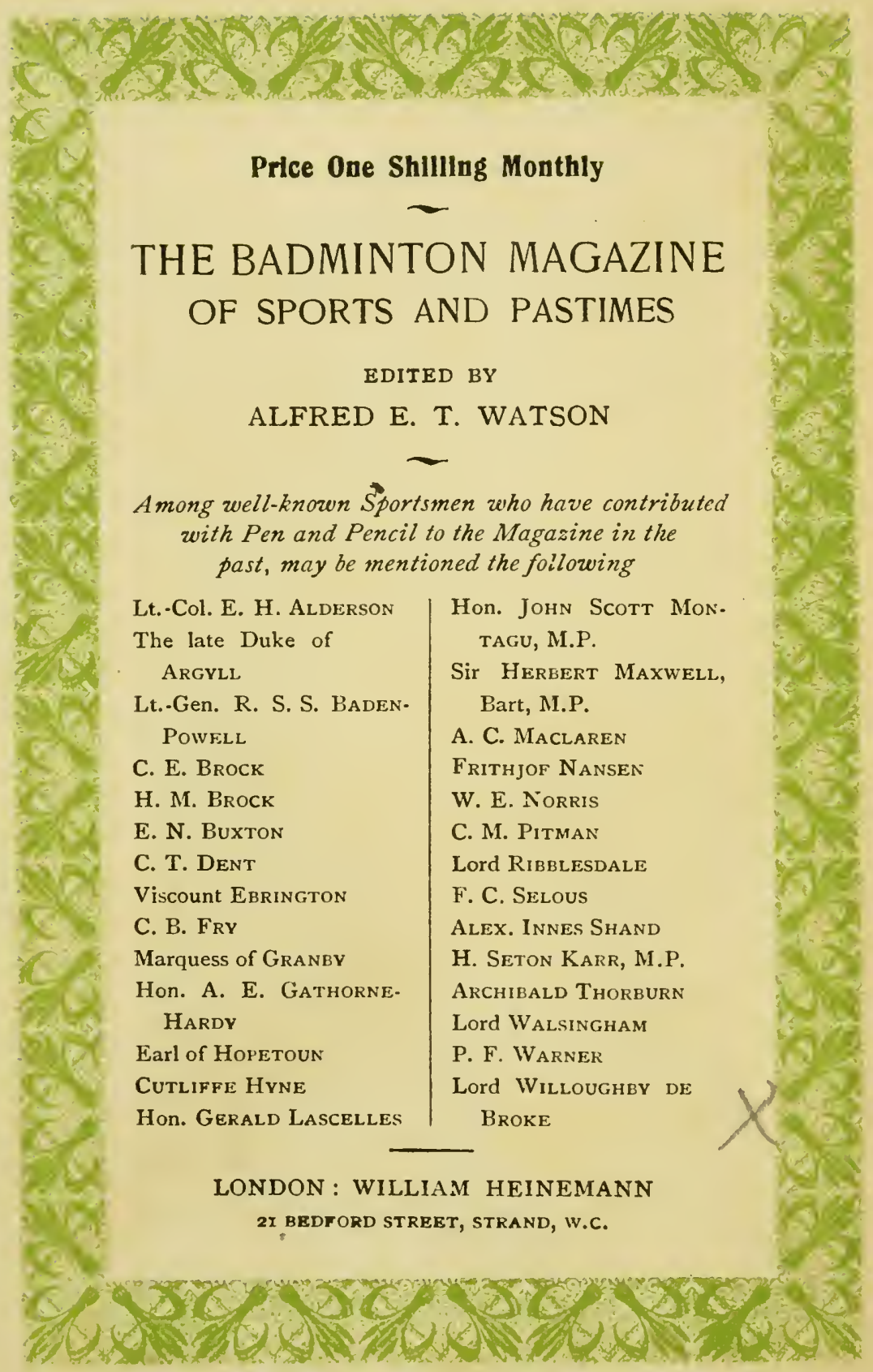


Webster Family Library of Veterinary Medicine Cummings School of Veterinary Medicine at Tufts University 200 Westboro Road Noth Grafton, MA 01536 


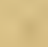

$-$ 
